TFM Trabajo Fin de Master

\title{
ECCLESIA IGNEUS: RECONSTRUCCIÓN DEL PATRIMONIO PERDIDO
}

\author{
María Isabel Puerto Fernández
}

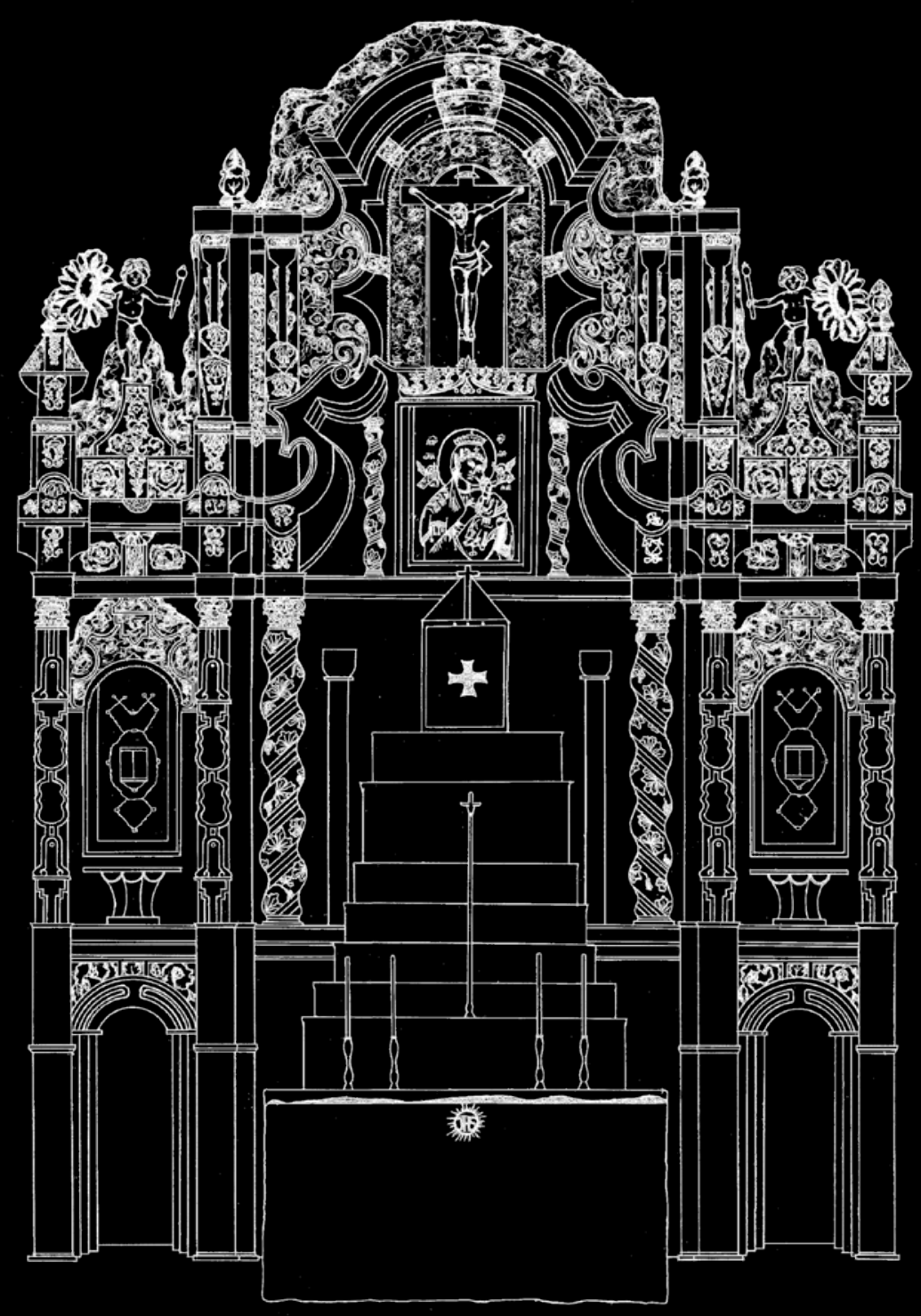





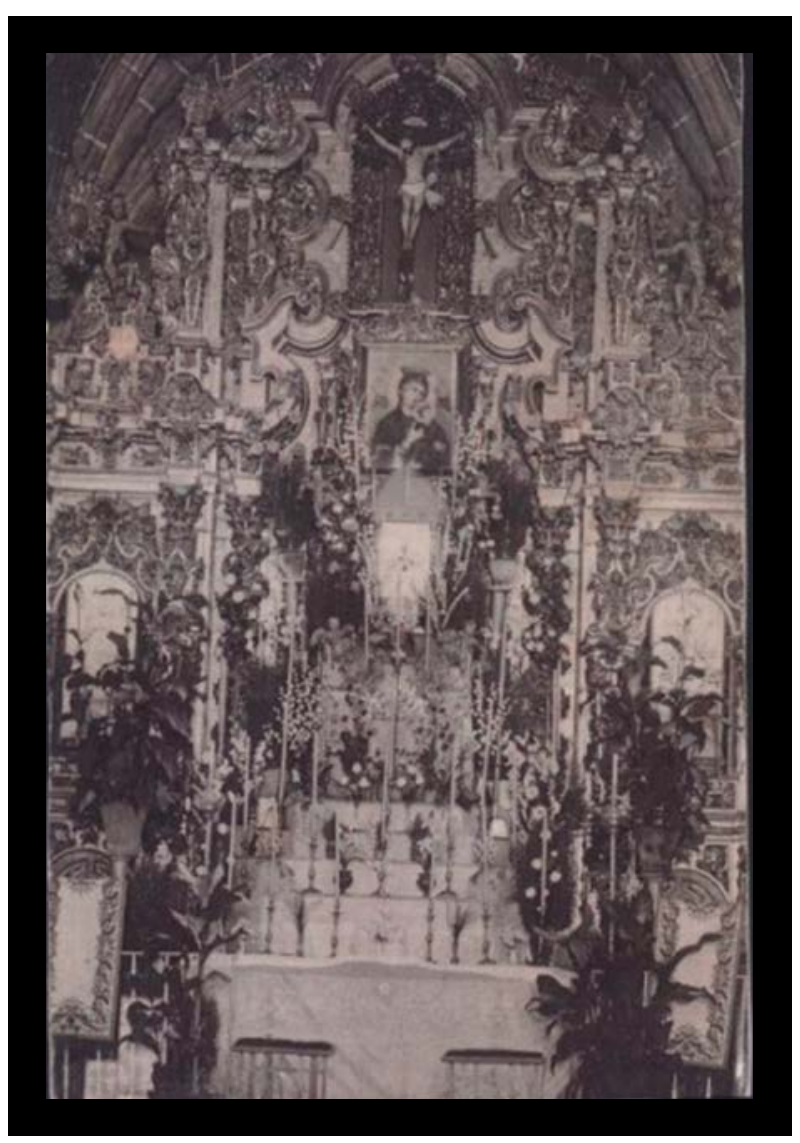



TFM Trabajo Fin de Master

\section{ECCLESIA IGNEUS: RECONSTRUCCIÓN DEL PATRIMONIO PERDIDO.}

Máster dibujo: creación, producción, difusión. Linea: Dibujo y conservación del patrimonio.

\section{MARÍA ISABEL PUERTO FERNÁNDEZ}

Trabajo final de Máster Dirigido por: Asunción Jodar Miñarro Dpto. Dibujo Septiembre 2016. 



\section{$\mathbf{R}_{\text {esumen }}$}

Abstract

Corría finales del siglo XV cuando en la localidad Cordobesa de Alcaracejos se erigió una pequeña parroquia de estilo gótico mudéjar, con un magnifico retablo dorado en el altar mayor. Fue en 1937 cuando un bombardeo de la Guerra Civil Española acabó con la humilde iglesia, aunque de importante valor histórico - artístico. Es aquí la investigación y recopilación de datos de cómo fue, cómo se construyó y cómo era la vida de los mojinos ${ }^{1}$ en torno a esta desaparecida iglesia de Alcaracejos, y ser descrita a través del arte del dibujo.
It was the end of the century XV when in the locality of Alcaracejos (Córdoba) a small parish in gothic - mudejar style was erected, with a magnificent gold altarpiece in the communion table. It was in 1936 when a bomb of the Spanish Civil War finished off with the modest church, which had significant historical - artistic value.

The investigation and summary of information how it was, how it built and how it was the life of the mojinos around the missing church of Alcaracejos, and to be described across the drawing art.

1 Se trata del gentilicio oficial de los vecinos de la localidad. Su origen se debe al habitad en la zona del ave Cyanopica cyanus cooki, popularmente conocido como mojino. 



\section{Palabras clave}

\section{Keywords}

Dibujo del patrimonio - Retablos perdidos Guerra Civil Española - Estilo Gótico Parroquias de granito.
Drawing Heritage - Lost altarpieces - Spanish Civil War - Gothic Style - Parish Granite . 



\section{$\dot{I}_{\text {nuice }}$}

Introducción Pp. 21

Objetivos Pp. 23

Metodología Pp. 25

Contextualización Histórica Pp. 28

Descripción física de la Iglesia Pp. 35

Imaginería Pp. 46

El retablo mayor Pp. 52

Origen del retablo de Alcaracejos Pp. 52

Descripción del retablo de Alcaracejos Pp. 53 Investigación práctica Pp. 63

Referentes Pp. 70

Conclusión Pp. 74

Anexos Pp. 74

Índice de imágenes Pp. 75

Bibliografía Pp. 78

Agradecimientos Pp. 85

Curriculum Vitae Pp. 86 


\section{Introducción}

Éste proyecto trata de recuperar un legado perdido, la iglesia de San Andrés de Alcaracejos, a través de la recopilación documental y la representación visual por medio del dibujo, para así acercar a los vecinos de la villa de Alcaracejos su historia y sus raíces, además de aportar al mundo una investigación realizada con especial pasión: patrimonio histórico- artístico de Alcaracejos, en busca de mis raíces.

Junto con el arte, la disciplina que más me ha interesado a lo largo de mi vida es la historia. Por este motivo he querido unir ambos ámbitos de conocimiento para desarrollar una investigación de las dos facetas que más me apasionan y así llegar a una hipótesis, tanto visual como narrativa. Más aun me apasiona cuando se trata de una investigación que gira en torno a mis raíces, a mi pueblo natal y a su modo de vida y cultura. Ser de las pocas personas que se han interesado por el patrimonio local y comarcal en la zona me enorgullece y complace. Siento que puedo ayudar a los vecinos de la zona a comprender su pasado y contribuir al desarrollo cultural de la Comarca de los Pedroches.

Ya comenzaron a indagar sobre el patrimonio histórico- artístico en la Comarca de los Pedroches, y en especial en Alcaracejos algunas personas las cuales me han ayudado para la realización del presente trabajo de investigación. Nombres como José López Navarrete o Andrés Molinero Merchan entre otros, que debieron inquietarse al observar la poca información que hay en el entorno a pesar de poseer un rico patrimonio, ya no sólo artístico, también etnográfico, heráldico e incluso natural.

Así pues doy inicio a un proceso de investigación largo y probablemente costoso por la escasa información, para desarrollar una futura tesis doctoral y, además, asociarme a colectivos sin ánimo de lucro interesados en el patrimonio, personalmente en el ámbito artístico, de la Comarca de los Pedroches. Porque para entender el presente hay que conocer el pasado y así predecir el futuro.

(Fig. 1) Autor fotógrafo anónimo. (Alcaracejos, Córdoba. En torno a 1937). Iglesia de San Andrés en Alcaracejos tras el bombardeo de la Guerra Civil Española.Vista fachada principal. 



\section{Objetivos}

\section{Objetivo principal:}

- Reconstrucción del retablo del altar mayor de la desaparecida parroquia de San Andrés en Alcaracejos (Córdoba).

- Reconstrucción del conjunto eclesiastico de San Andrés en una futra tesis doctoral.

\section{Objetivos generales:}

- Investigar nuestra historia aplicando el dibujo como eje central.

- Investigar sobre el patrimonio artístico cordobés, concretamente en la localidad de Alcaracejos.

- Reconstruir el patrimonio arquitectónico y escultórico a través del dibujo.

- Reconstrucción del patrimonio perdido para ofrecer a mí localidad natal, Alcaracejos.

- Investigar y analizar obras relevantes del contexto medieval cordobés en el que nos encontramos, así como a los artistas (artesanos de la época) que los llevaron a cabo.

- Proponer una manera diferente del proceso de creación y proyección en la práctica del dibujo.

- Estudiar interrelaciones entre la historia y el medio artístico.

- Materializar las ideas del proyecto con herramientas gráficas actuales. Aplicaciones digitales.

- Poder difundir el trabajo desarrollado a través de los nuevos soportes digitales, además de métodos tradicionales.

- Analizar la repercusión de las formas del patrimonio antiguo a través de la obra gráfica actual: Adecuación y reconstrucción del patrimonio en la era digital.

- Repercusión social: poder ofrecer a la sociedad dicha investigación. 



\section{Metodología}

Esta investigación gira en torno a la reconstrucción visual de modo hipotético a través del dibujo de la iglesia de San Andrés en Alcaracejos. El dibujo como elemento esencial para la investigación pero, para llegar a ello, primeramente hay que centrarse en búsqueda y análisis del contexto histórico - artístico - cultural - económico y social en el que nos encontramos, entre los siglos XV - XVI en la Comarca de los Pedroches, Córdoba.

Pues bien, cómo comento, el primer paso para comenzar la investigación es contextualizar la parroquia de San Andrés, apoyándome en la recopilación de documentos de la época, a pesar de la escasa información al respecto ${ }^{1}$.

Todo este proceso está ayudado de documentos históricos: archivos parroquiales en los que cabe destacar lo censos, defunciones o bautizos; archivos municipales los cuales ayudan a contextualizar la localidad en el siglo XV; archivos provinciales, ayudan a comparar con otras localidades vecinas de la época; archivos eclesiásticos, donde detallan y describen la desaparecida parroquia; fotografías del siglo XX de la parroquia antes de ser destruida, pertenecientes a vecinos de la localidad; testimonio de personas mayores que la han conocido en vago recuerdo; análisis de otras parroquias y ermitas vecinas; bibliografía.

Tras la recopilación de información en diversos formatos, comienzo a crear la hipótesis visual por medio del dibujo. Aclarar que en este proyecto de investigación me centro en el retablo del altar mayor. Digamos pues, que la investigación sobre la reconstrucción de la parroquia está dividida en dos partes: Una primera reconstrucción del retablo del altar mayor como protagonista; Una segunda parte más genérica sobre la reconstrucción del conjunto eclesiástico, la cual será desarrollada en una futura tesis doctoral.

Esta investigación se está llevando a cabo a través del método deductivo. En primer lugar parto de un hipótesis, en este caso visual: la iglesia que queremos reconstruir poseía elementos propios del gótico aunque con influencia mudéjar, de materiales pobres y austeros. Las parroquias vecinas tenían las dimensiones de 129 pies de largo, 36 de ancho y 42 de alto $^{2}$, por tanto la iglesia debía ser...; en cuanto al retablo según las descripciones "dorado y de muy buena talla"3 debía de contener...

De esta forma, a través de la deducción puedo sacar los elementos que componían la iglesia de San Andrés, de Alcaracejos, en concreto el retablo mayor. Llevar esta deducción a formato visual por medio del dibujo y así plantear una hipótesis.

* Nota aclaratoria: aunque el presente proyecto está centrado en el desarrollo y representación del retablo mayor, considero que es de verdadera importancia contextualizar y describir la parroquia a la que hacemos referencia, junto con la sociedad y economía del momento de construcción. Porque como comenté en apartados anteriores: para entender el presente hay que conocer el pasado.

1 Tras el bombardeo de la Guerra Civil Española, los documentos eclesiásticos desaparecieron junto con la obra arquitectónica.

2 Descripción de la iglesia de San Mateo de Villanueva del Duque. Construcción por Hernán Ruiz III.

3 OBISPADO DE CÓRDOBA. (1875 (3)). Almanaque del obispado de Córdoba. Córdoba, España: publicado por diario de Córdoba. 




\section{Contextualización histórica}

Era marzo de 1937 en Alcaracejos, provincia de Córdoba. La parroquia de San Andrés es utilizada como refugio de uno de los bandos de la Guerra Civil Española . La aviación del bando contrario bombardea la zona quedando completamente destruida.

Un legado histórico - artístico convertido completamente a escombros. Alcaracejos no tuvo la suerte que tuvieron sus pueblos vecinos de salvar las pocas riquezas artísticas que poseía. La crueldad e ignorancia de la guerra dejan rastro para toda la vida. Ya sólo quedan vagos recuerdos en la mente de nuestros mayores que la conocieron "La iglesia de Alcaracejos tenía un retablo precioso, nada que envidiar al de los pueblos vecinos"1.

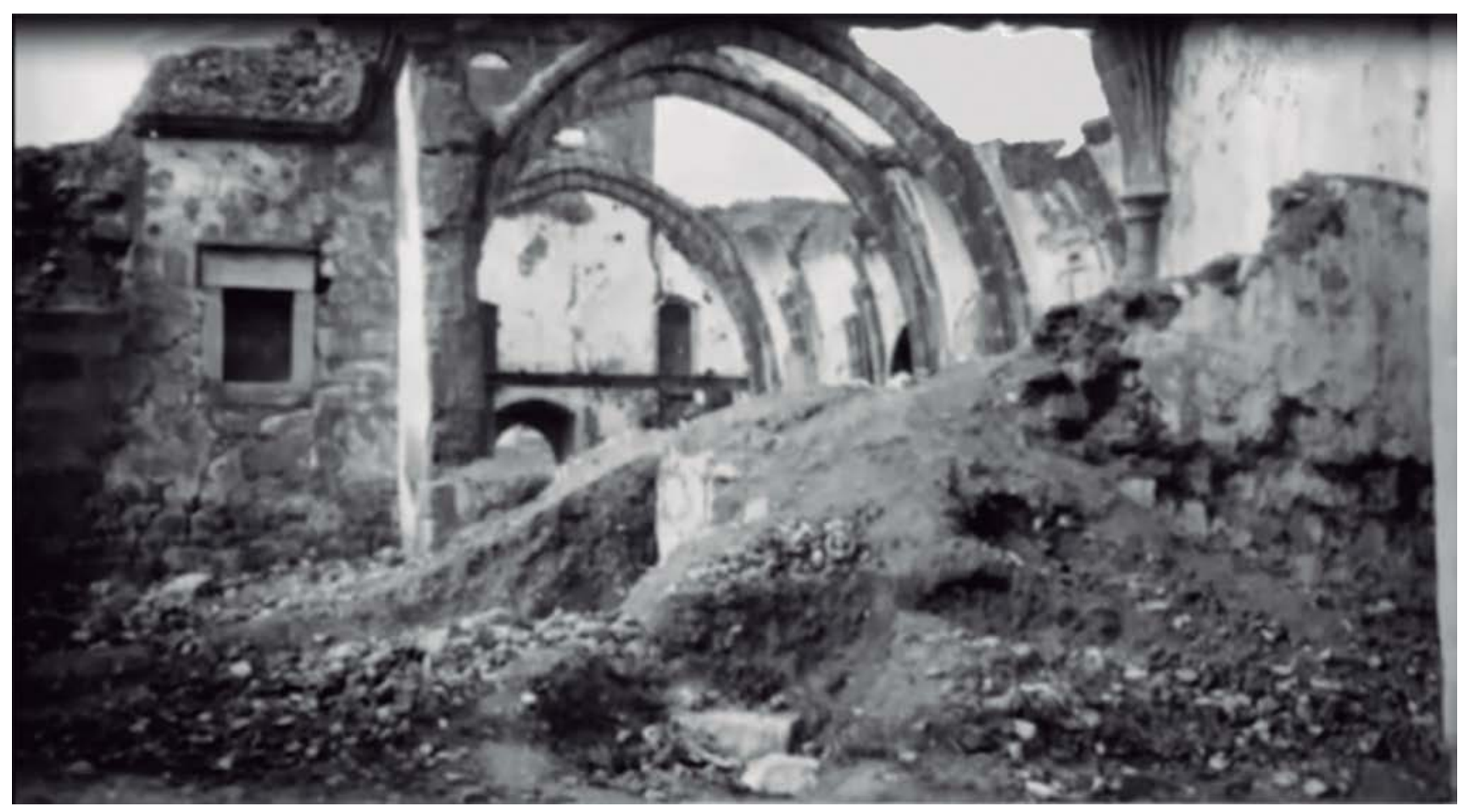

Fig.2

1 Palabras testimoniales de Teresa Puerto Fernández 


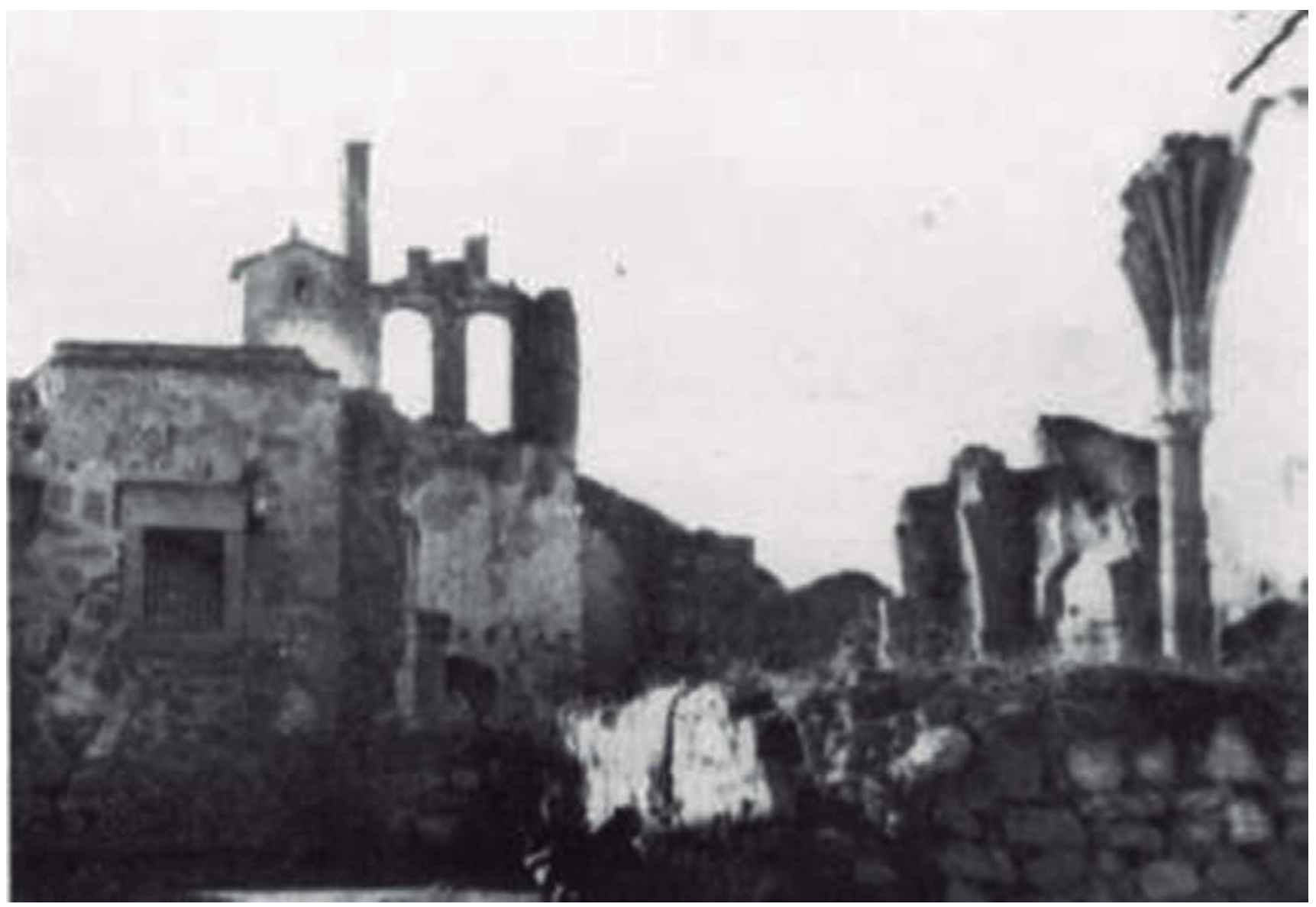

Fig. 3

(Figs. 2, 3) Autores fotógrafos Anónimos. (Alcaracejos, Córdoba. En torno a 1937). Iglesia de San Andrés en Alcaracejos tras el bombardeo de la Guerra Civil Española. Vista del interior de la parroquia ya derruida.

Podemos observar que ambas fotografías están tomadas desde el mismo punto de vista pero en diferente momento temporal, puesto que en una se representa mayor destrucción que en otra. 
Corría finales del siglo XV principios del siglo XVI. En el valle de los Pedroches surge la necesidad de construir iglesias para el culto cristiano - católico propio del Medievo. Así la mayoría de las villas inician sus construcciones parroquiales. Entre estas parroquias se encuentra la de la villa de Alcaracejos ${ }^{1}$, una pequeña aldea con población reducida y perteneciente a la villa de Torremilano ${ }^{2}$.

Podemos saber que en la zona era muy usual la explotación de ganado porcino, ovino y vacuno y en cuanto a agricultura la siembra del trigo junto con otros cereales, los viñedos y la dehesa. Ésta era la principal actividad financiera de cada una de las villas, la que sirvió para contribuir en las construcciones de las parroquias. No se queda sin importancia las donaciones por parte de los vecinos, las obras de caridad, los acopios de bienes propios del Antiguo Régimen y los censos en dichas parroquias. Así pues, en esta época, las construcciones de edificios religiosos eran de especial importancia, incluso en los núcleos urbanos más empobrecidos como Alcaracejos.

Se cree que la construcción de la parroquia de San Andrés fue por albañilería popular, siguiendo los modelos de otras parroquias vecinas como la de San Juan Bautista en Hinojosa del Duque ${ }^{3}$, las ermitas de Villanueva del Duque, la parroquia de Torremilano, la parroquia de Torrefranca o la de Pedroche, según nuestros mayores, ésta última la más parecida a la de Alcaracejos. Bien es cierto que los parecidos entre las antiguas fotografías de la desaparecida iglesia, y las parroquias de los pueblos vecinos son evidentes.

La construcción surge tras un modelo de aprendizaje común en la época, los gremios. En todos los oficios (curtidos, herreros, canteros, carpinteros, etc.) había un maestro, un oficial y un aprendiz de mayor a menor importancia. Así pues gracias a estos gremios se realizaron numerosas obras en el Medievo. Estos oficios artesanales eran realizados con un espíritu de total perfección, digno de elogio, intentando ofrecer un acabado satisfactorio tanto en la funcionalidad como en la vistosidad, clara está la influencia material y económica limitada.

Uno de los gremios más importantes del Valle de los Pedroches pertenece al oficio de los canteros de granito. Una de las canteras más importantes se encontraba en la población de Alcaracejos ${ }^{4}$. Muy probablemente los canteros que realizaron la Catedral de la Sierra fuesen los mismos que construyesen la de Alcaracejos. Así podemos ver que cada grupo de canteros tenía su símbolo identificativo labrado en las molduras de las bóvedas, pilares y arcadas. El principal material de las construcciones parroquiales, por tanto, es la piedra de granito 5 .

1 Alcaracejos se fundó en el siglo XV después de la conquista de Córdoba. Fue aldea de Torremilano hasta 1488. Posteriormente perteneció al grupo de las siete villas de Pedroche hasta 1660 que es vendida por Felipe IV a los marqueses del Carpio. En 1747 vuelve a la corona.

2 Torremilano junto con Torrefranca forman la actual localidad de Dos Torres.

3 Iglesia de San Juan Bautista o Catedral de la Sierra, construida por la familia de arquitectos Hernán Ruiz. Arquitectos de la diócesis de Córdoba.

4 Otras de las canteras que existían en el Valle de los Pedroches eran las pertenecientes a Belarcazar, Hinojosa del Duque, Pozoblanco, Dos Torres y Conquista.

5 Granito: roca ígnea plutónica constituida por cuarzo, feldespato y mica. Igneus en latín, relacionado con el fuego. 

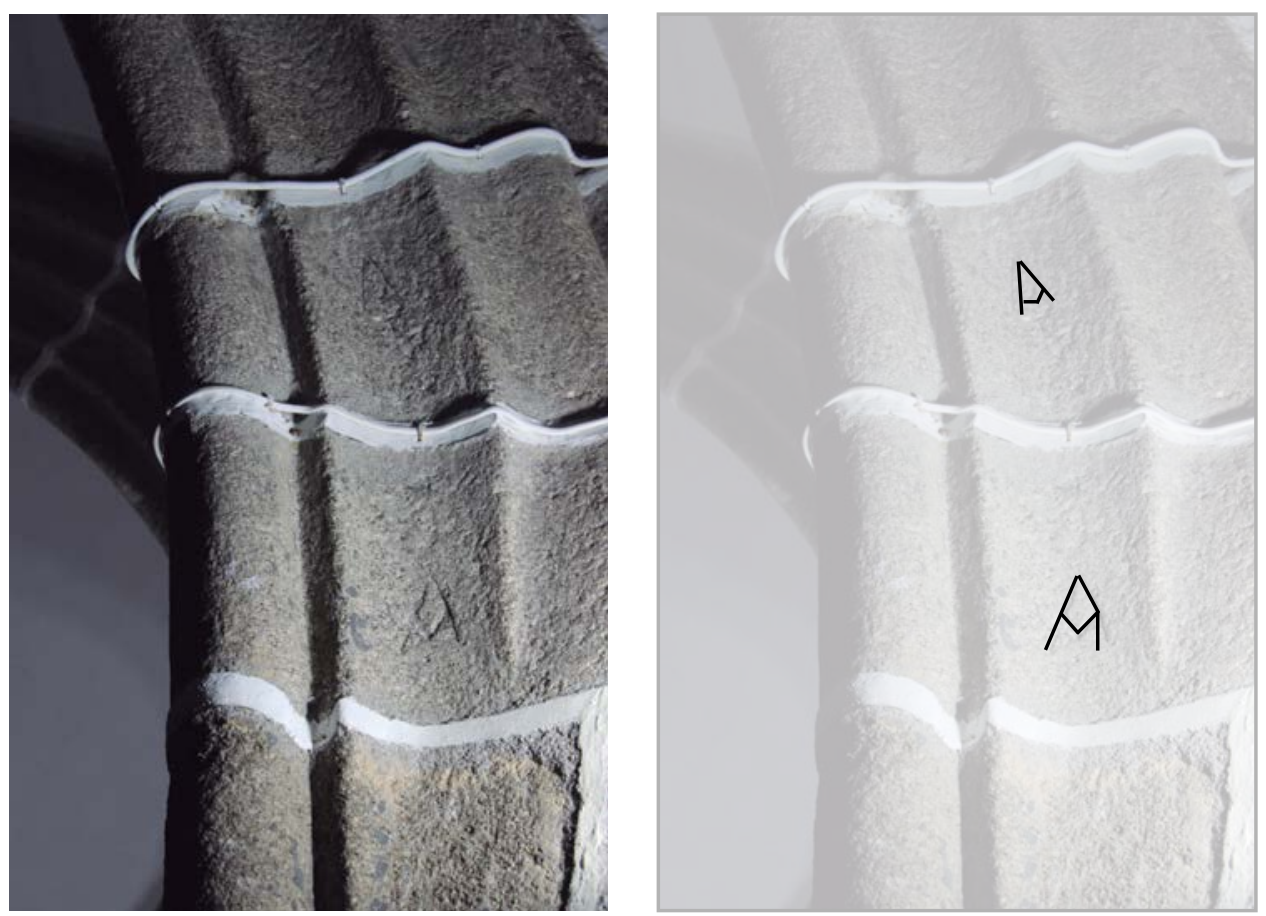

Fig. 4
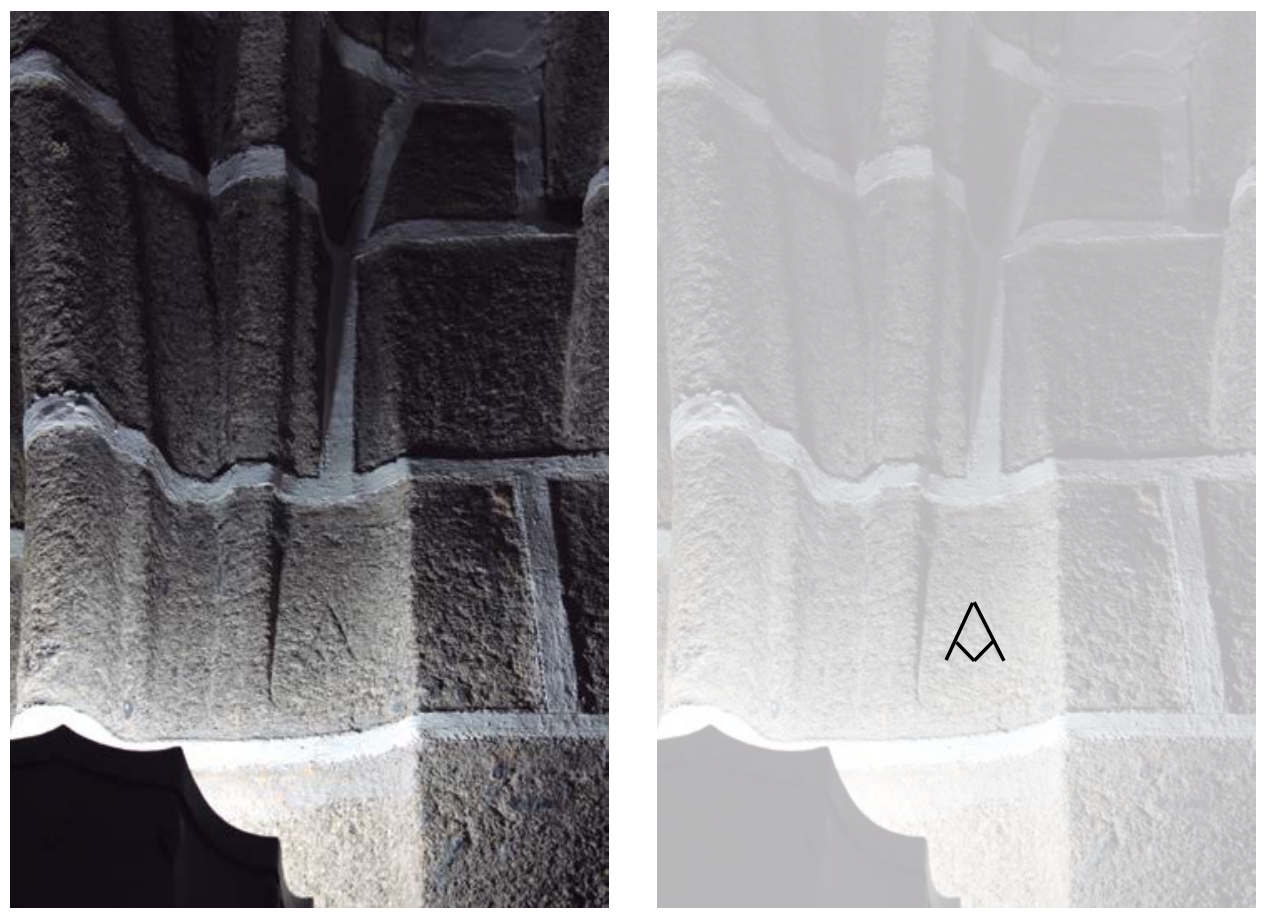

Fig. 5 

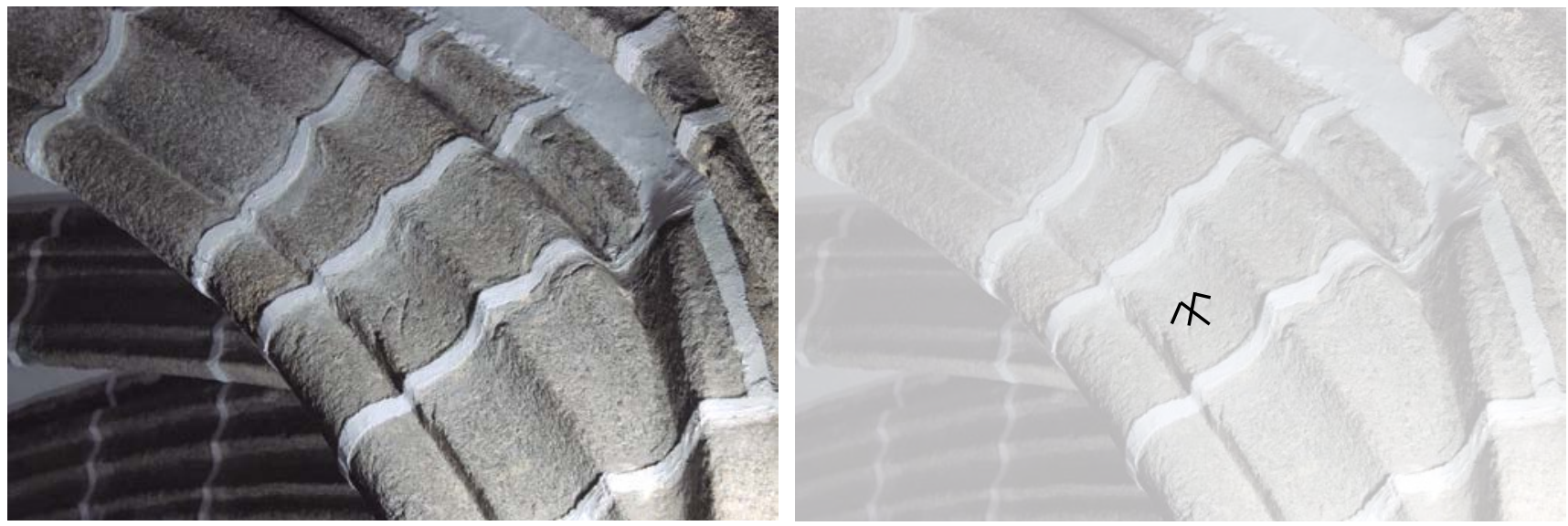

Fig.6
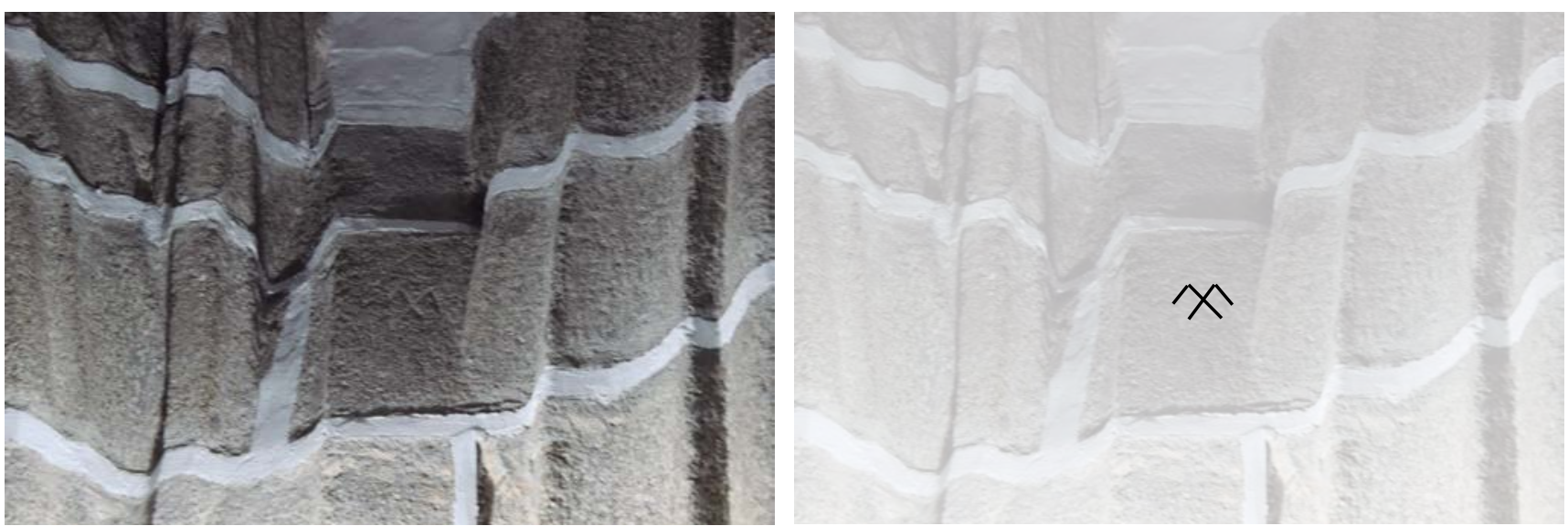

Fig. 7

(Figs. 4, 5, 6, 7, 8) Fotografía de Ma Isabel Puerto Fernández. (Hinojosa del Duque, Córdoba. Enero de 2016). Iglesia de San Juan Bautista de Hinojosa del Duque, también conocida como Catedral de la Sierra.

Molduras de granito que componen las diferentes arcadas y pilares que sustentan el edificio. En ellas se observa las inscripciones de los maestros canteros. 

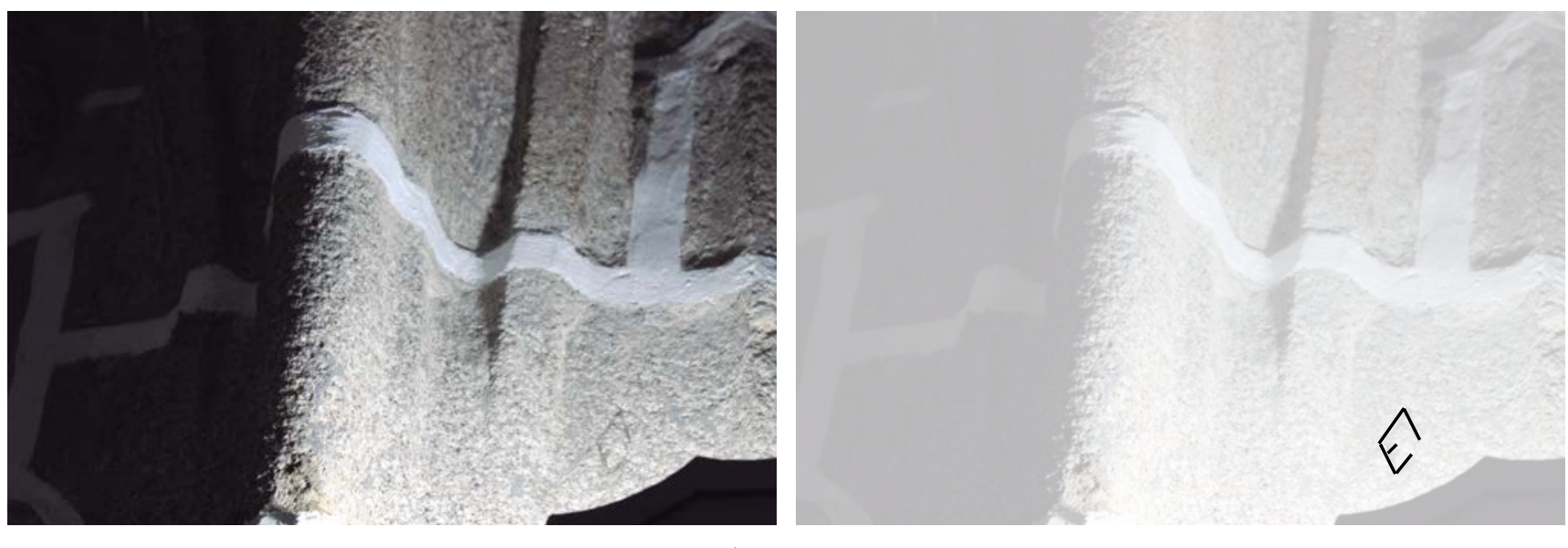

Fig.8 



\section{Descripción física de la iglesia}

"De muy buena construcción"1, la parroquia estaba caracterizada por la austeridad ornamental. Era de estilo gótico- mudéjar realizada con muros de mampostería con el material del granito como protagonista. Poseía un pequeño vestíbulo que daba paso a una única y extensa nave de salón con presbiterio al final. El acceso al prebisterio era escalonado y separado por barandas en forja y revestimiento en pan de oro (muy probablemente incorporación más tardía). Sobre el prebisterio se erigía una sólida bóveda ojival también conocida como crucería, tal y como se aprecia en una de las fotografías del retablo (Fig. 15, pág. 40). Al igual que la Iglesia de San Juan Bautista de Hinojosa del Duque, se sostenía gracias a los arcos apuntados que recorrian el interior de la nave, descargando sus pesos sobre adosadas columnas. Dichos arcos se encontraban labrados en piedra y decorados con nervaduras y ménsulas.

Al igual que el resto de las construcciones eclesiásticas de la épcoa, no faltaba el púlpito en la nave principal, muy probablemente adosado a una columna: "Después de la hermosa procesión del Rosario, subió al púlpito nuestro infatigable cura"2.

La fachada principal miraba hacia el oeste y estaba situada al saliente. Con "Esbelta línea de su campanario, posada de cigüeños"', la parroquia poseía una única torre de planta cuadrada, de un sólo nivel no muy alto y campanario, situada en la parte central de la fachada principal. El campanario muy probablemente con dos campanas pequeñas y una grande.

Esta fachada consta de una entrada al templo caracterizada por el estilo gótico tardío (Fig. 18, pág. 43). Con arco apuntado doblado en el intradós de tres archivoltas o arquivoltas con labrado de flechas en la clave y un pequeño conopio superior. A su vez se encuentra enmarcada por un alfiz pometeado con semiesferas. Al mismo tiempo se hallan fajadas al alfiz y a los arcos tres líneas de las mismas esferas. Las dovelas y los sillares son de granito. Perteneciente al final del siglo XV, presenta clara influencia de estilo Reyes Católicos, muy parecida a las portadas de las parroquias del Salvador de Pedroche y a la de San Juan Bautista de Hinojosa del Duque (Figs. 19 y 21, pág. 44).

Esta portada se conserva en la actualidad en la nueva parroquia de San Andrés, utilizándose como entrada/salida lateral del templo. También se conserva una pila bautismal de la misma época, de estilo gótico mudéjar muy rica en formas. Ésta pila se encontraba en un baptisterio situado en la parte izquierda de la entrada al templo, junto al vestíbulo. También se conserva una pequeña campanilla de bronce con inscripciones en relieve desgastadas diciendo Hemony Me Fecit- anno 1569 s.

1 OBISPADO DE CÓRDOBA. (1875 (3)). Almanaque del obispado de Córdoba. Córdoba, España: publicado por diario de Córdoba.

2 CORRESPONSAL DESCONOCIDO. (7 de octubre de 1924). De Alcaracejos, el Santo Rosario. El defensor de Córdoba: diario católico, año 26. ( $\left.\mathrm{n}^{\circ} 8114\right)$. Córdoba. Pp. 4.

3 GARCIA LOVERA, Juan A. (diciembre de 1929). Alcaracejos. La voz: diario gráfico de información, año 10. (n 3749 ).

Córdoba. Pp. 6.

4 Otro pórtico muy similar es el del convento de Santa Clara en Belarcazar, en el patio interior al convento.

5 Refiriéndose al año de creación de la campanilla por el autor en el 1569. 
Por otro lado descarto que la techumbre estuviese constituida por una armadura de madera labrada con motivos geométricos como en el caso de otras iglesias de los alrededores como Pedroche ${ }^{1}$. No debía de poseer dicha techumbre por la disposición de las arcadas que se pueden observar en una de las fotografías tomadas tras la contienda civil ${ }^{2}$. Los muros debieron de ser encalados en su interior en épocas posteriores tal y como se aprecia en las fotografías de la parroquia en ruinas.

$\mathrm{Y}$ en cuanto a la solería, baldosas con formas geométricas en blanco y negro. Este dato es otorgado por testimonios de mayores, además de poder confirmarlo en una de las imágenes que inmortalizaron el retablo. Podemos saber que esta pavimentación fue realizada ya en el siglo XX, así lo refleja el diario La Voz:

Persuadido el Ayuntamiento de la absoluta necesidad del alcantarillado, ha dotado del mismo a varias calles de la Villa sin olvidar la pavimentación (...). También,- y conviene hacero resaltar, por las comodidades que esta reforma proporciona al vecindario - se ayudo con la cantidad de dos mil pesetas a la pavimentación de la Iglesia parroquial. Del mismo modo, costeó el ayuntamiento la hermosa calzada hecha en la puerta de dicho templo". ${ }^{3}$

A inmediaciones de la parroquia se encontraba el antiguo cementerio construido en 1821 y que en 1842 se traslado a la ermita del la Magdalena.

Los motivos decorativos debieron ser muy similares al de las iglesias cercanas con fuerte simbología propia de la época, repetidas hasta la saciedad. Mensajes de doctrina a través de imágenes, sin olvidar los valores artísticos y principios estéticos propios del gótico (Fig. 9, pág. 38).

Así como los retablos, con importante relevancia en el interior de una iglesia, con una gran carga conceptual. Un patrimonio artístico material que no siempre ha corrido suerte, como es el caso del retablo de Alcaracejos, pero que por causa de su brillante artisticidad permanece en la actualidad a través de la documentación originada por nuestros antepasados.

El caso de Alcaracejos no es el único en toda la comarca. Otros retablos como el de San Juan Bautista ${ }^{4}$ también desaparecieron en los conflictos bélicos del último siglo.

Otros muchos sí han corrido con la suerte, dando gracias al legado que nos ha quedado en otros pueblos de la comarca así podemos hacernos una hipótesis visual de cómo eran los retablos desaparecidos, entre ellos el de Alcaracejos.

Según Casas Deza:

La iglesia parroquial, que está dedicada a San Andrés, tiene seis altares, y una capilla que es el sagrario. El retablo del altar mayor es obra del s. XV o muy a principios del S. XVI y en él se ven muy buenos adornos de talla y pinturas en tabla nada despreciables. Según las costumbres de aquellos tiempos

1 En los pedroches había importantes talleres de carpintería mudéjar en los siglos XV- XVI.

2 Fig. 2 , pág. 28

3 GARCIA LOVERA, Juan A. (diciembre de 1929). Alcaracejos. La voz: diario gráfico de información, año 10. (n 3749 ). Córdoba. Pp. 6.

4 Desapareció en la Guerra Civil Española el retablo barroco de la Catedral de la Sierra, Iglesia de San Juan Bautista. Proyecto del maestro cordobés Jorge Mejía y ejecución de Juan Espejo. 
está el sagrario de éste altar al lado del evangelio, y por haberse hecho otro sagrario nuevo en el medio, está colocado en el antiguo un rostro divino.

La iglesia, que es de pobre fábrica, tiene una nave, y en los libros parroquiales principian: los bautismos en 1554; los de matrimonios en 1578; y los difuntos en 1615. Tiene un solo cura. Inmediato a la iglesia está el cementerio que se hizo en $1821 .^{1}$

Como bien describe Casas Deza, la parroquia también poseía capillas laterales a la única nave. El autor habla de seis altares y según testimonios de personas que la conocieron hablan de cuatro pero, después de casi un siglo, la memoria y el recuerdo proporciona información imprecisa. Según dichos testimonios, no poseían retablo aunque sí estaban muy bien decoradas con flores y otros ornamentos. Por el contrario en los Anales de la comisión Provincial de monumentos históricos y artisticos de Cordoba, se afirma que la "Iglesia parroquial de Alcaracejos con varios retablos, especialmente el del altar mayor, de algún valor histórico"’.

Una de las capillas muy probablemente perteneciese al propio baptisterio, lugar donde se encontraba la pila bautismal. Según testimonios, en esta capilla se encontraba la Virgen de los Bautizados. No podemos verificar este dato.

Sabemos que en las capillas o altares laterales, uno estaba dedicado a la Inmaculada Concepción. Así lo hace constatar un artículo escrito en la Revista mariana, dedicándole un apartado a la Inmaculada de Alcaracejos: "Hay una capilla en la parroquia y una escultura antigua de algún mérito artístico. Es mucha la devoción a este misterio"3 (Fig. 24, pág. 48).

En otra de las capillas se encontraba la figura de Jesús Nazareno, afirmación dada por testimonios de mayores, además de verificar con el Diario de Córdoba de comercio, industria, administración, noticias y avisos con fecha de 23 de abril de 1909, pág. $2^{4}$.

Posiblemente San Isidro Labrador y la Virgen de Guía tuviesen el privilegio de poseer cada figura una capilla para sus adoraciónes, puesto que se tratan de los patrones de la localidad. Al igual que San Andrés patrón de la parroquia.

Por otro lado se habla de la Virgen del Rosario en diferentes artículos periodísticos de finales del siglo XIX y principios del XX. Así pues, quizás esta advocación mariana también podría encontrarse en alguna de las capillas pero este dato es solo una hipótesis.

1 RAMIREZ DE LAS CASA DEZA, L.M. (1986). Corografía histórico- estadística de la provincia y obispado de Córdoba. Córdoba, España: Monte de Piedad y caja de ahorros de Córdoba, confederación española de cajas de ahorros. P. 81

2 DESCONOCIDO. (1926). Anales de la comisión Provincial de Monumentos Históricos y Artísticos. Córdoba, España: imprenta Hospicio. Pp. 73

3 CORRESPONSAL DESCONOCIDO. (diciembre de 1923). La devoción a la Inmaculada en Córdoba y su provincia. Revista mariana: publicación mensual con censura eclesiástica dedicada a fomentar la devoción a la Santísima Virgen, año 1. (nº 4). Córdoba. Pp. 47.

4 CORRESPONSAL DESCONOCIDO. (23 de abril de 1909). Alcaracejos. Diario de Córdoba de comercio, industria, administración, noticias y avisos, año 60. (n 17959). Córdoba. Pp. 2. 

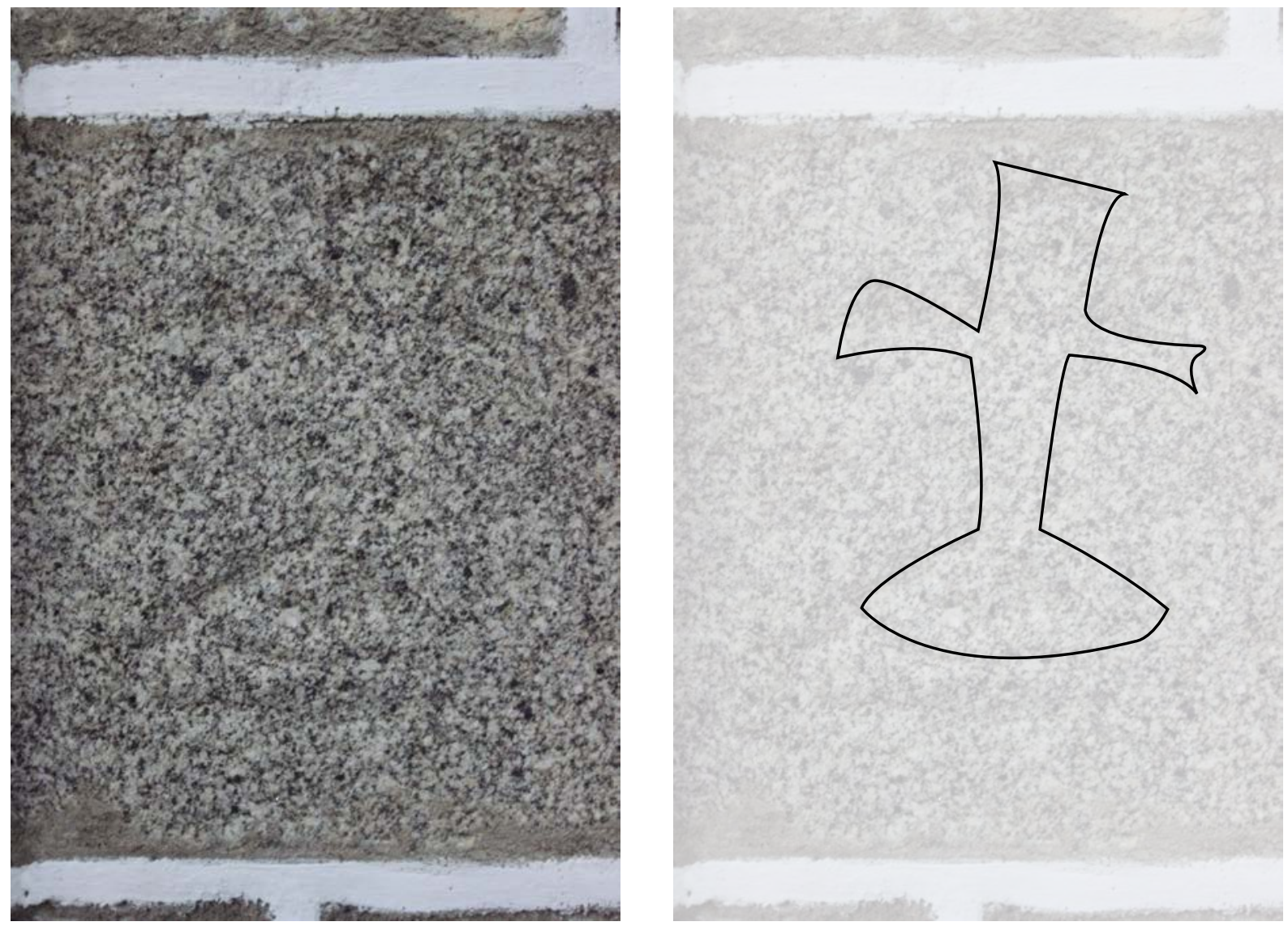

Fig. 9

(Fig. 9) Fotografía de M $M^{a}$ Isabel Puerto Fernández. (Hinojosa del Duque, Córdoba. Enero de 2016). Iglesia de San Juan Bautista de Hinojosa del Duque, también conocida como Catedral de la Sierra.

Sillar con labrado simbólico en forma de cruz latina. 


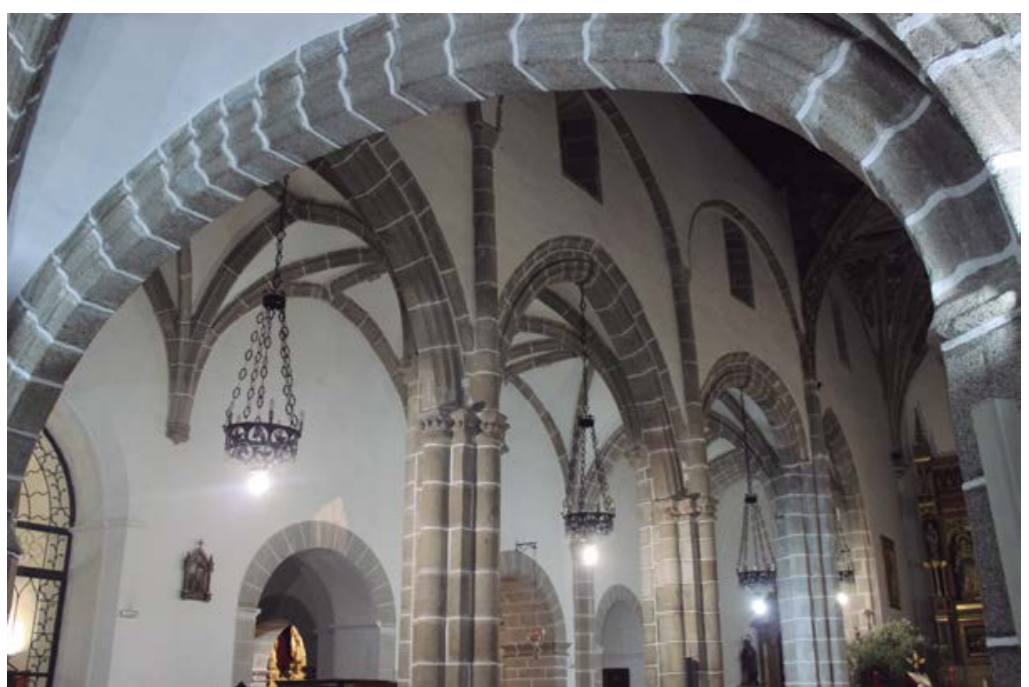

Fig. 10

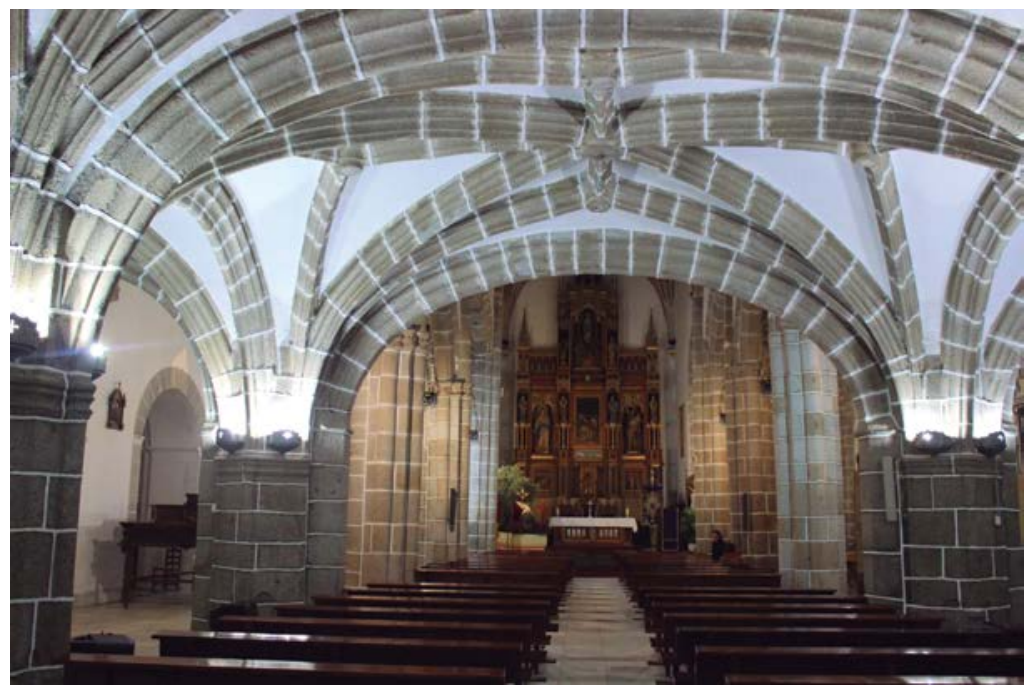

Fig. 11

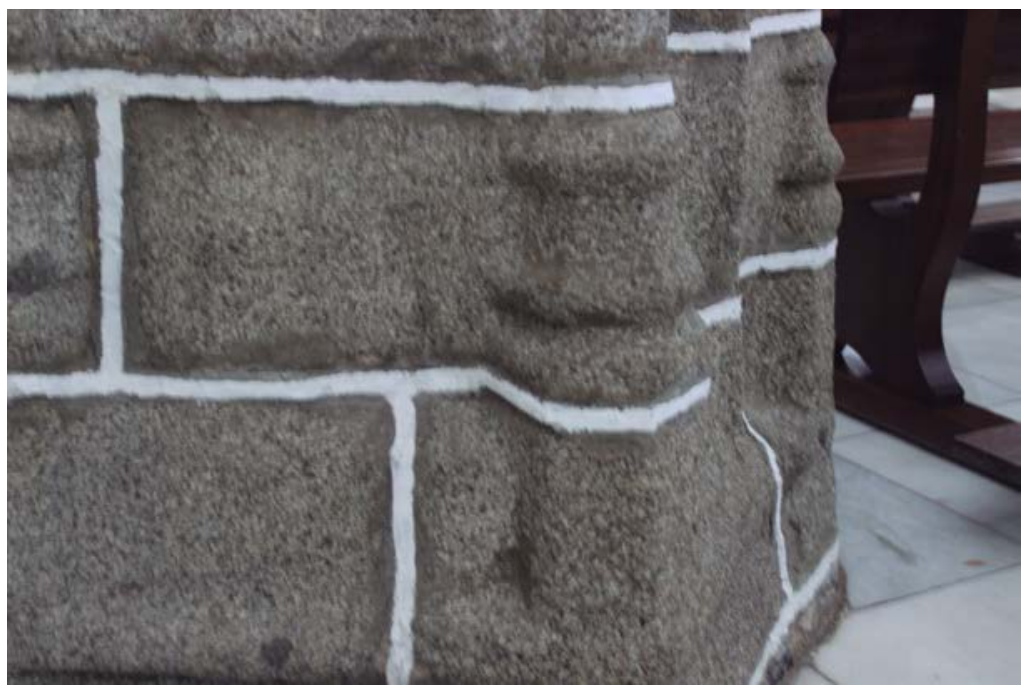

Fig. 12
Las presentes imágenes muestran un posible reflejo de lo que fue en su día la iglesia de San Andrés. Estas imágenes pertenecen a la Iglesia de San Juan Bautista de Hinojosa del Duque, construcción en torno al final del Siglo XV por Hernan Ruiz I. De este modo, por la cercanía entre localidades y por compartir el mismo periodo de construcción, deduzco que ambas iglesias debieron ser similares. Claro está que la de Alcaracejos, como he comentado anteriormente, más austera y pobre, de una sóla nave. 


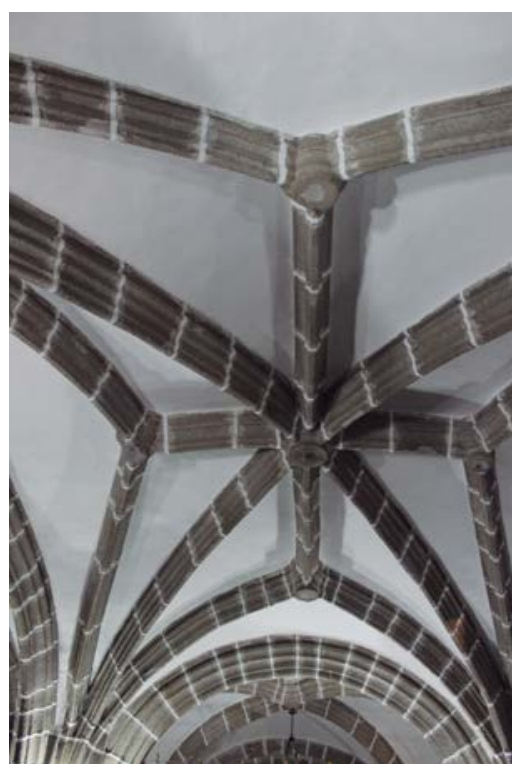

Fig. 13

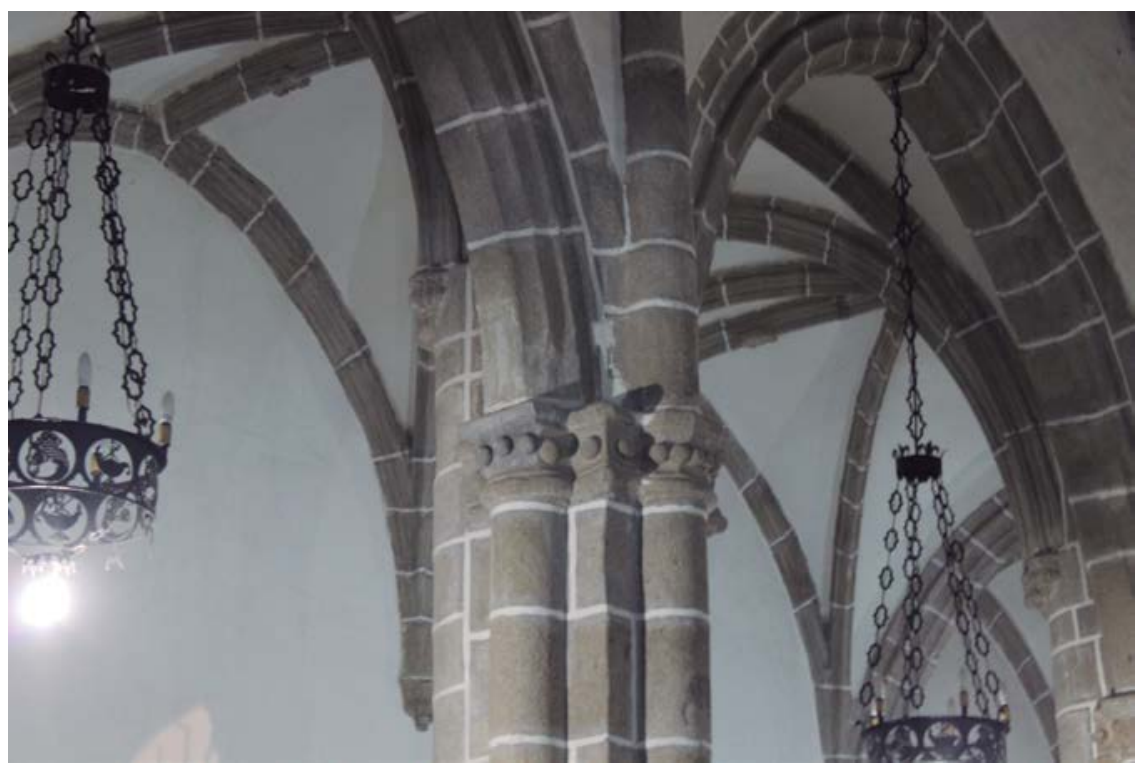

Fig. 14

(Figs. 10, 11, 12, 13, 14) Fotografía de $\mathrm{M}^{\mathrm{a}}$ Isabel Puerto Fernández. (Hinojosa del Duque, Córdoba. Enero de 2016). Iglesia de San Juan Bautista de Hinojosa del Duque, también conocida como Catedral de la Sierra.

Bóvedas de crucería; arcos apuntados; muros de sillería de granito; elementos decorativos de semiesferas o pometeados.

(Fig. 15) Autor fotógrafo anónimo. (Alcaracejos, Córdoba. Fotografía tomada poco antes de la Guerra Civil Española). Prebisterio y altar mayor de la Iglesia de San Andrés de Alcaracejos.

Bóveda de crucería con arcos apuntados propios del Gótico y sillares de granito. Al igual que la basílica de San Juan Bautista anteriormente comentada. (apreciación en la parte superior de la fotografía).

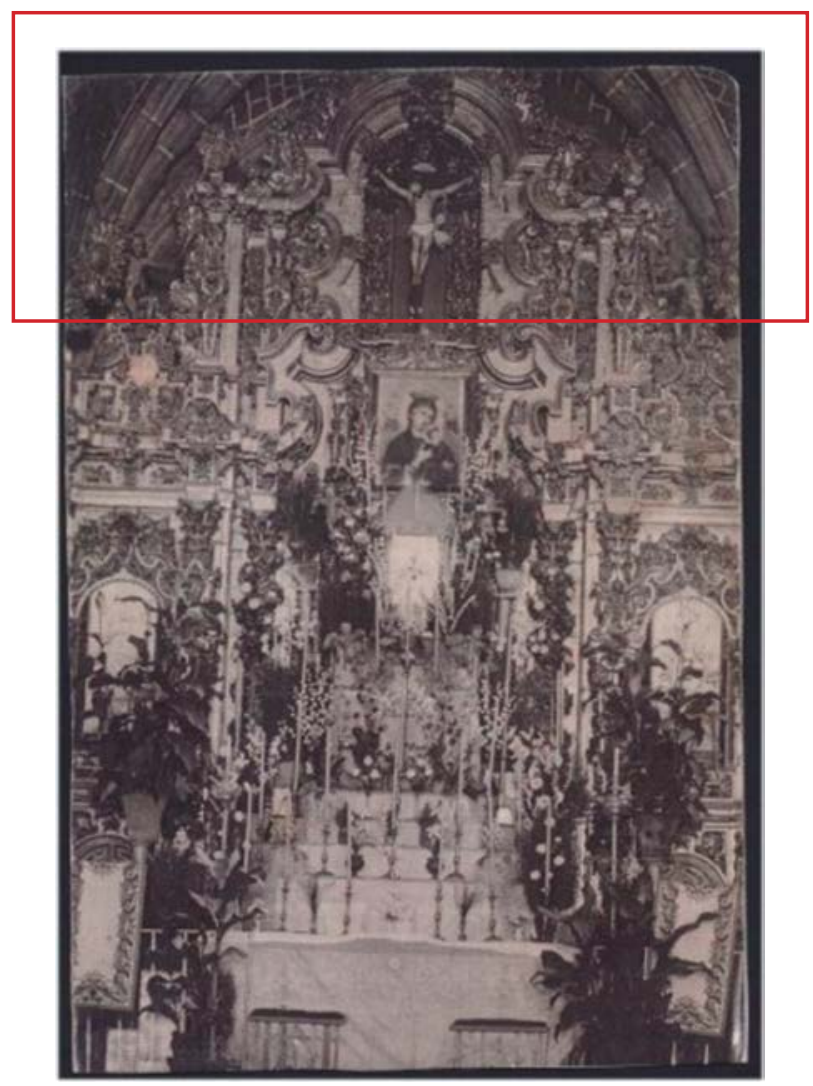

Fig. 15 


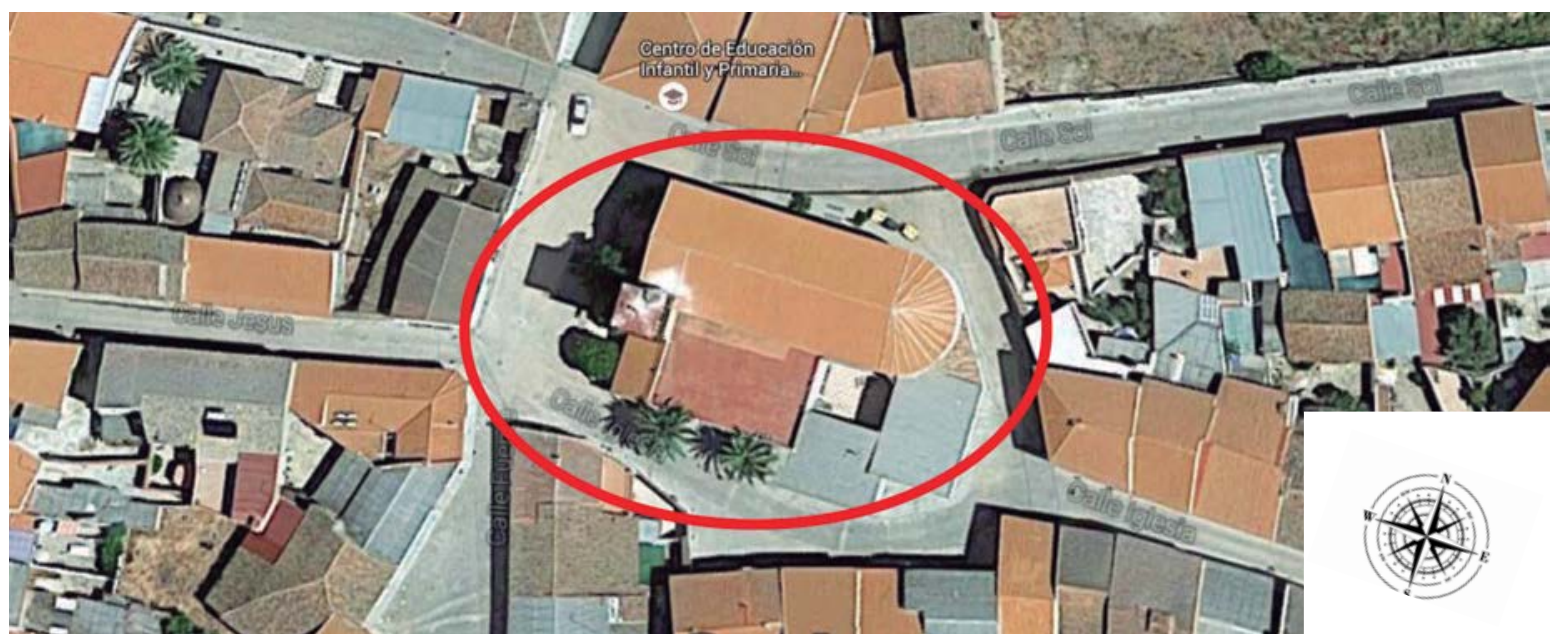

(Fig. 16) Fotografía tomada por Google Maps. (Alcaracejos, Córdoba. Rescatado

Fig. 16 de la web en Junio de 2016). Vista aerea de la actual Iglesia de San Andrés de Alcaracejos.

Medidas longitudinales de la actual iglesia:

- Largo: 44 m. (144'35 pies)

- Ancho: 24'54 m. (80'53 pies)

Fuente de información Google Maps.

Medidas longitudinales de la iglesia de San Mateo de Villanueva del Duque:

- Largo: 129 pies.

- Ancho: 36 pies.

- Alto: 42 pies.

Medidas descritas por Ramirez de las Casas Deza.

El edificio religioso estaba situado en la parte norte de la localidad. La fachada principal de la actual iglesia mira hacia el Oeste mientras que el prebisterio mira hacia el Este, al igual que las descripciones de la antigua iglesia. Por tanto llego a la conclusión que la anterior parroquia estaba situada justo en el mismo lugar y misma orientación que la actual. Verificado por testimonios de nuestros mayores.

En cuanto a las dimensiones podemos deducir que la desaparecida iglesia poseía unas magnitudes muy probablemente parecidas a las de la actual construcción, incluso a la parroquia de la localidad vecina de Villanueva del Duque, puesto que son villas muy cercanas y similares en lo que respecta a riqueza local y extensión territorial.

Por otro lado tomo como información relevante las palabras de Teresa Puerto Fernández, quien en su infancia pudo conocer el edificio eclesiástico: "la iglesia estaba justo donde está ahora la nueva y miraba hacia el mismo lado. La iglesia era lo que es ahora el salón de actos de la parroquia y la casa del cura era lo que es ahora la iglesia". 


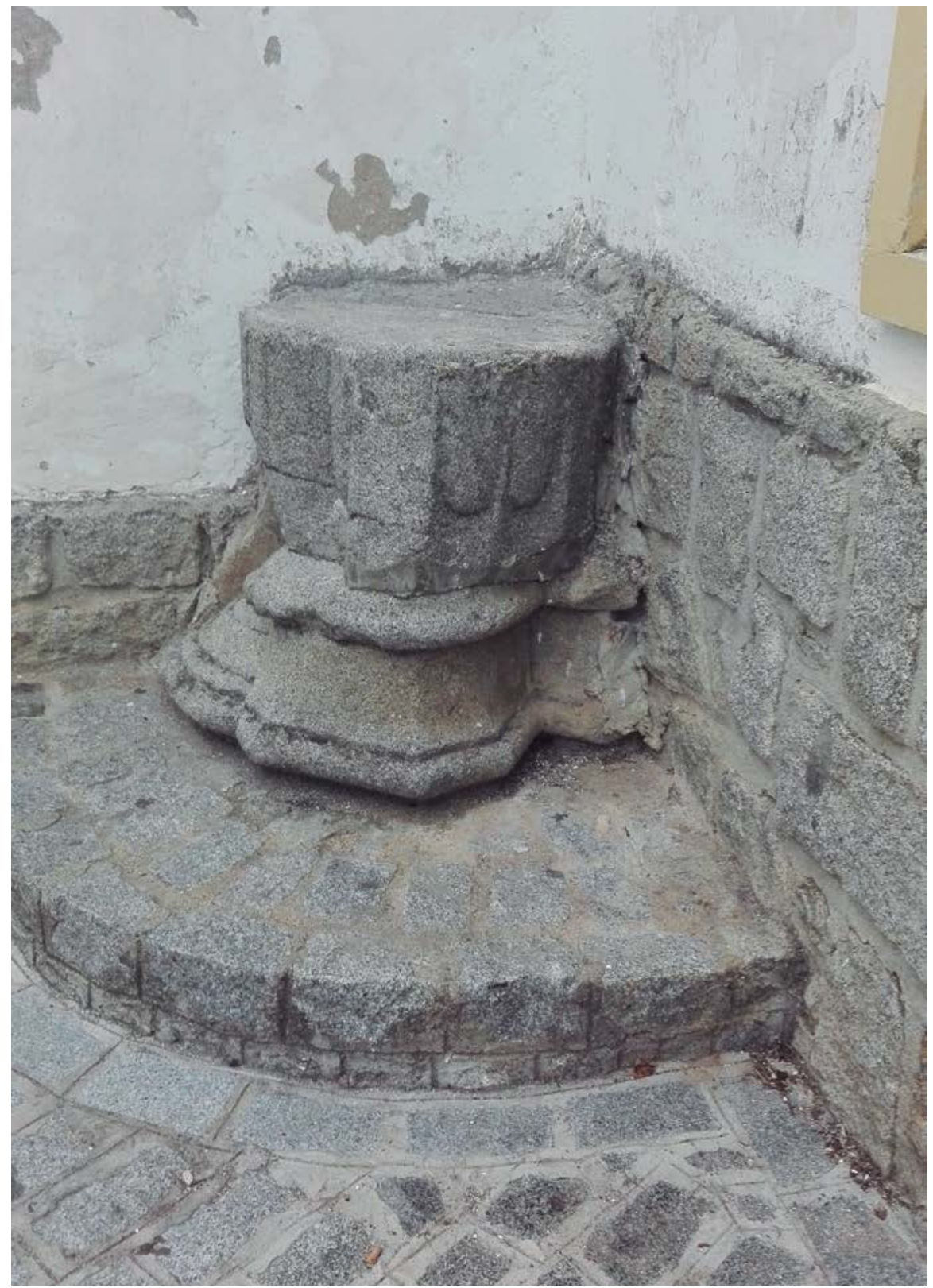

Fig. 17

(Fig. 17) Fotografía tomada por María Isabel Puerto Fernández. (Alcaracejos, Córdoba. Enero de 2016). Base de columna o pilar de la Iglesia de San Andrés de Alcaracejos.

Resto de la antigua iglesia. Actualmente se conserva como recuerdo en el exterior de la nueva construcción. 


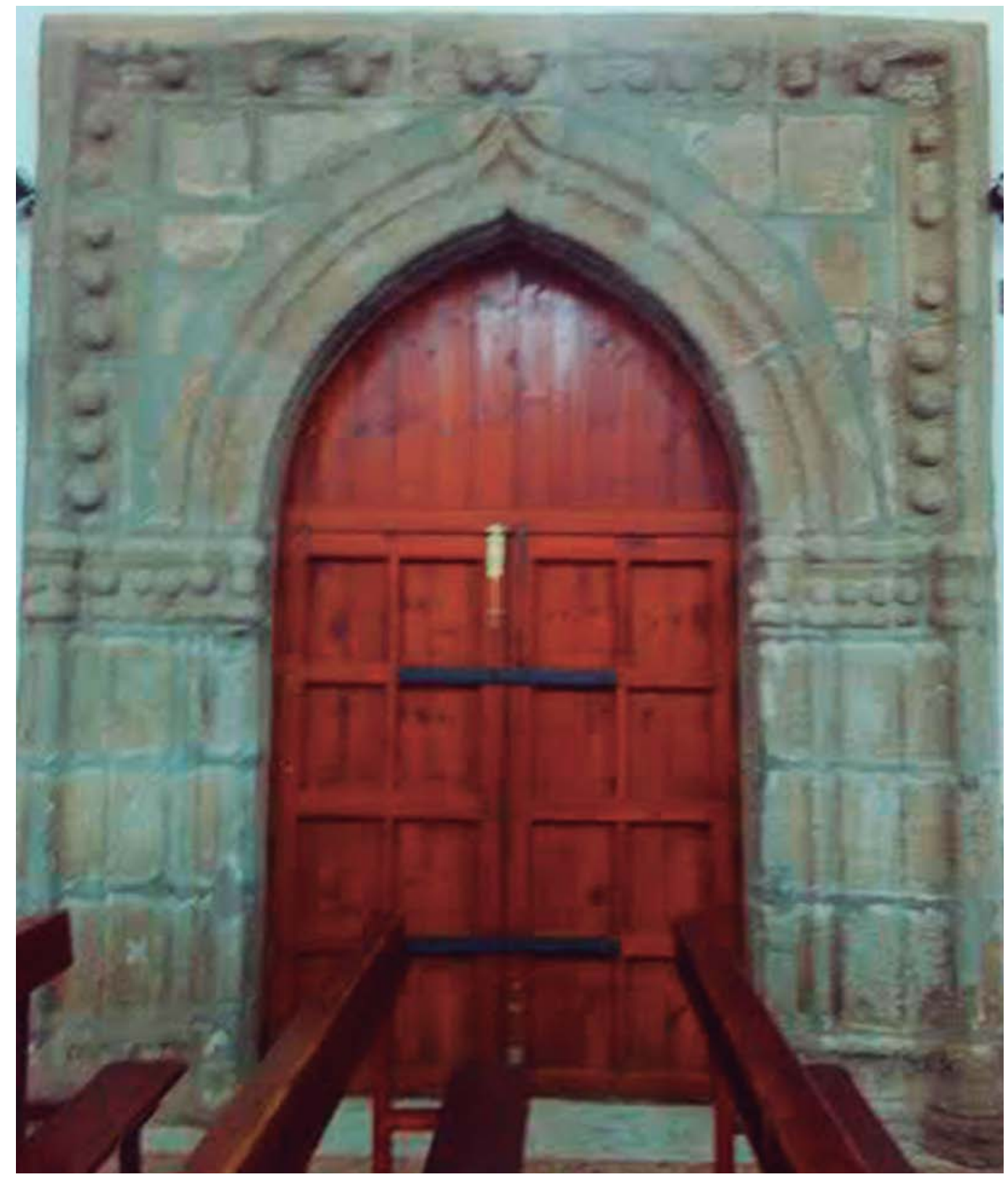

Fig. 18

(Fig. 18) Fotografía tomada por María Isabel Puerto Fernández. (Alcaracejos, Córdoba. Mayo de 2016). Antigua portada principal de estilo gótico de la Iglesia de San Andrés de Alcaracejos.

Vista interior del actual templo utilizada como puerta lateral. En su origen, dicha portada estaba orientada hacia el exterior de la basílica y utiizada como puerta principal. 


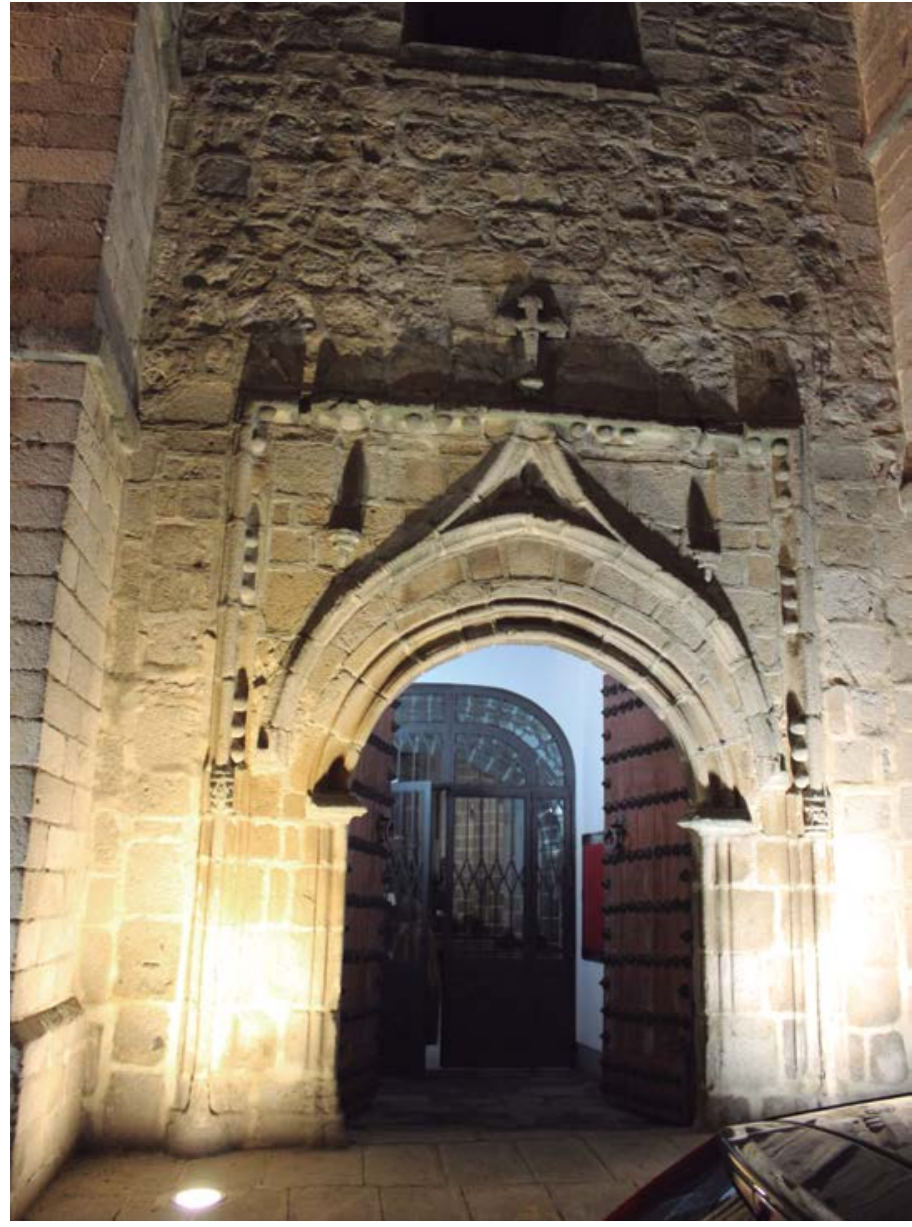

Fig. 19

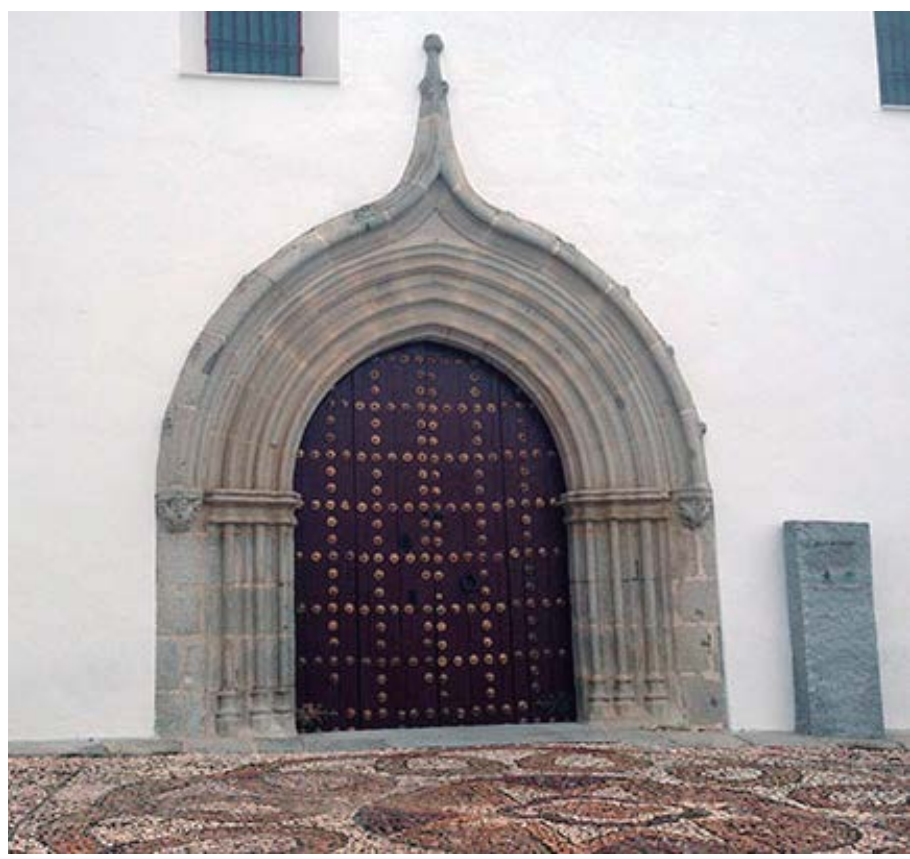

Fig. 21

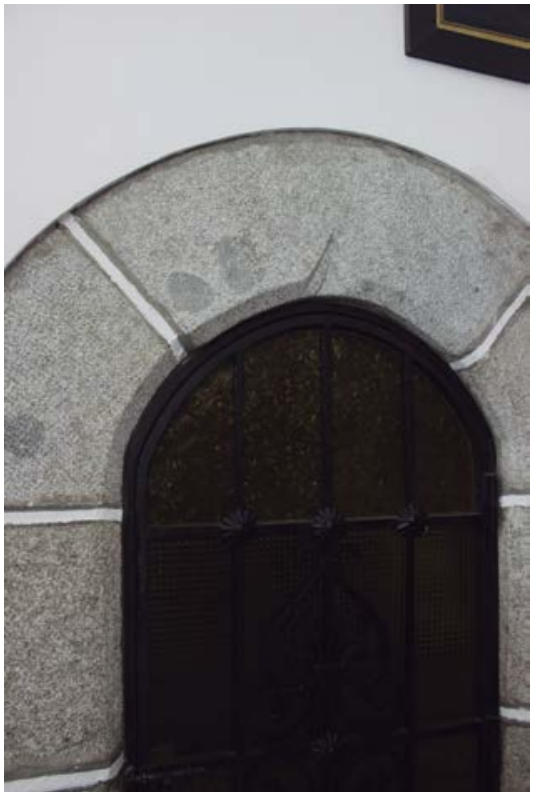

Fig. 20

(Fig. 19) Fotografía tomada por María Isabel Puerto Fernández. (Hinojosa del Duque, Córdoba. Enero de 2016). Portada de estilo gótico de la Iglesia de San Juan Bautista de Hinojosa del Duque.

Similitud en los arcos y el pometeado con la portada de la iglesia de Alcaracejos.

(Fig. 20) Fotografía tomada por María Isabel Puerto Fernández. (Hinojosa del Duque, Córdoba. Enero de 2016). Pequeña puerta del interior de la parroquia, de estilo gótico de la Iglesia de San Juan Bautista de Hinojosa del Duque.

Compuesta de sillares y con un pequeño conopio en la parte superior. Similitud con el estilo de la parroquia de Alcaracejos.

(Fig. 21) Autor fotógrafo anónimo. (Pedroche, Córdoba. Fotografía rescatada de la web a mayo de 2016). Portada de estilo gótico flamíngero de la Iglesia del Salvador de Pedroche.

Similitud en los arcos conopiales con la portada de la iglesia de Alcaracejos. 

La iglesia de San Andrés, como cualquier otra iglesia Católica Cristiana, tuvo en posesión imágenes en talla que representaban a las distintas divinidades.

En la parroquia no faltó la figura de San Andrés, patrón de la iglesia de Alcaracejos, ni tampoco los patrones de la localidad: la Virgen de Guía y San Isidro Labrador.

El retablo también se encontraba adornado con tallas propias del gótico, incluso añadidos de épcoas posteriores como renacentistas o barrocos.

- San Andrés. Patrón de la parroquia a la cual le da nombre. Esta figura debió ser una talla de finales del Siglo XV principios del siglo XVI, creada posiblemente en paralelo a la realización de la iglesia para rendirle homenaje en ella y por tanto de estilo gótico tardío.

En una de las fotografías del retablo, quizás realizada en un periodo más reciente, se puede deducir que en el ático, en la hornacina se encuentra el Santo, puesto que se aprecia una cruz sostenida con su mano derecha en forma de aspa, símbolo del martirio del Santo Apostol.

Se encuentra vestido con una túnica sujeta con un cordel en la parte de la cintura posiblemente de color marrón y faz barbuda. Está sostenido por una peana y decorado con adornos florales. (Fig. 22, pág. 48).

- Crucificado. Talla posiblemente creada entre el siglo XV y XVI. Probablemente perteneciente al monasterio franciscano de San Alberto del Monte que, junto con el retablo, fue donado a la iglesia de Alcarcejos tras la desamortización de Mendizabal. Esta figura se encuentra situada en la horanacina superior del retablo, tal y como se observa en una de las fotografías recuperadas, quizás sea la fotografía más antigua.

Se muestra a Cristo desnudo con un Paño de Pureza, perizonium, cubriendo los genitales.

El crucificado debía estar representado con cuatro clavos, según se puede observar la disposición de las extremidades inferiores. Parece no estár representado con un cuerpo demasiado martirizado, aunque en las rodillas se intuye rozaduras ensangrentadas. El rostro mirando hacia abajo, es dificil determinar en qué momento bíblico de la crucifixión está retratado, puesto que la calidad de la imagen no nos ofrece demasiados detalles.

Sí se aprecia un letrero en el madero con forma ovalada que posiblemente contenga las siglas latinas de Iesvs Nazarenvs Rex Ivdaeorvm, INRI.

— Inmaculada Concepción, o Purísima Concepción. Se halla retratada en una de las fotografías del retablo. Una figura realizada probablemente entre los siglos XVII - XVIII, según los rasgos de estilo, se encuentra posada sobre una peana y adornada con círios y telares a modo de hornacina. La figura se presenta con un rostro sereno con la mirada hacia abajo y con las manos unidas en acto de oración. La base se encuentra rodeada de ángeles como símbología cristiana de Ser superior y puro ante el hombre. Posee una corona como reina del cielo y una aureola de alambre dorado con doce estrellas, significado de las doce tribus de Israel. La vestimenta es muy común: túnica muy probablemente de color blanco (pureza) y capa muy probablemente de color azul (eternidad). 
Ésta figura fue sustituida en la parte central del retablo por motivo de su festividad tal y como se muestra en la fotografía (Fig. 24, pág. 48). Sin embargo, el resto del año permanecía en una de las capillas laterales de la parroquia.

- Virgen de Guia. Patrona de Alcaracejos desde principios del siglo XVI aproximadamente (no se conoce a ciencia cierta el año exacto). Era una estatuilla con el niño en brazos de pequeño tamaño de plata de modelo socia belli ${ }^{1}$, que se enccontraba en una caja metálica de bronce con argollas para ser cogidas al arzón de una silla de montar. Esta figura se perdió en la contienda Civil Española en la localidad de Hinojosa del Duque. Posteriormente, se realizó otra talla en madera de pino y pan de oro y con dimensiones similares a la desaparecida, de unos $25 \mathrm{~cm}$, que es la que actualmente se venera.

*Añadido: en el año 1954, durante la restauración de la ermita de la Virgen de Guia en Villanueva del Duque, se encontraron tapiadas unas tallas policromadas de la segunda mitad del siglo XIII, entre ellas la Virgen de Guía. No se conoce si esta imagen tambén era trasladada a Alcaracejos en romería.

- Santa Bárbara. Debido a la explotación minera en la localidad, y siendo Santa Bárbara la patrona de este colectivo obrero, cada cuatro de diciembre se realizaba un acto en su honor. Por tanto abro la hipótesis de que la Santa debió estar en el interior de la basílica y fuese destruida en la contienda. La imagen que aquí se muestra, es una escultura posterior quizás del siglo XX. (Fig. 28, pág. 50).

- Santa Ana. Según Luís María Ramírez de las Casas Deza, "se ve colocada en un Altar de la parroquia ${ }^{2}$ ". La imagen de Santa Ana pertenecía a una antigua ermita de la población ya desaparecida, y que probablemente fuese trasladada a la parroquia del municipio. No hay más documentación al respecto y por tanto es casi imposible saber más detalles acerca de la representación escultórica de la Santa.

- San Nicolás de Tolentino. Debía estar en la antigua iglesia puesto que desde el año 1649, los vecinos celebraban su festividad tras la finalización de una peste. El ayuntamiento en agradecimiento hizo voto de ofrecer una misa en su honor en julio de cada año. No hay documentación fotográfica ni descriptiva sobre la imagen.

— Jesús Nazareno. No hay imágenes ni documentación que describan la escultura en cuanto a año de realización y a ornamentación.

1 Traducción del latín "compañera de batallas". Se trata de una imagen que, situada en el arzón de la silla de montura, acompañaba a los caballeros de la Reconquista. De aquí proviene el nombre de Virgen de la Guía.

2 RAMIREZ DE LAS CASA DEZA, L.M. Corografia histórico- estadística de la provincia y obispado de Córdoba. Córdoba, España: Monte de Piedad y caja de ahorros de Córdoba, confederación española de cajas de ahorros. P. 81 


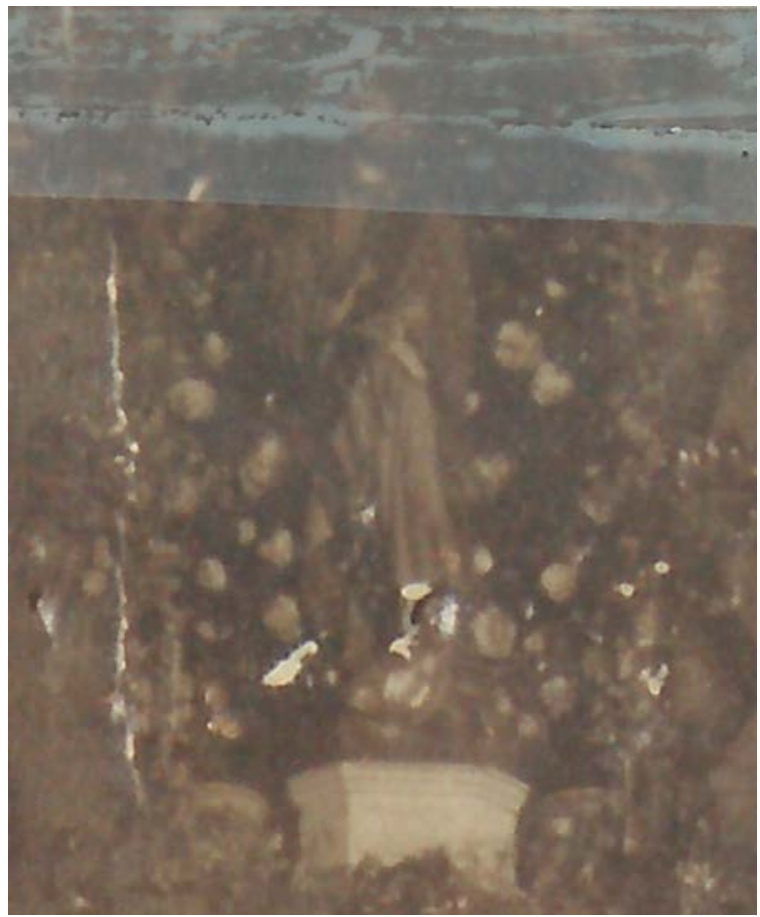

Fig. 22

(Fig. 22) Autor fotógrafo Anónimo. (Alcaracejos, Córdoba. Fotografía tomada en torno a las décadas de 1920, principios de 1930) Representación de San Andrés Detalle fotográfico del retablo (Fig. 39, pág 62)

(Fig. 23) Autor fotógrafo Anónimo. (Alcaracejos, Córdoba. Fotografía tomada en torno a las décadas de 1920, principios de 1930) Representación de Crucificado. Detalle fotográfico del retablo (Fig. 38, pág 61)

(Fig. 24) Autor fotógrafo Anónimo. (Alcaracejos, Córdoba. Fotografía tomada en torno a las décadas de 1920, principios de 1930) Representación de Inmaculada Concepción.

Detalle fotográfico del retablo (Fig. 39, pág 62)

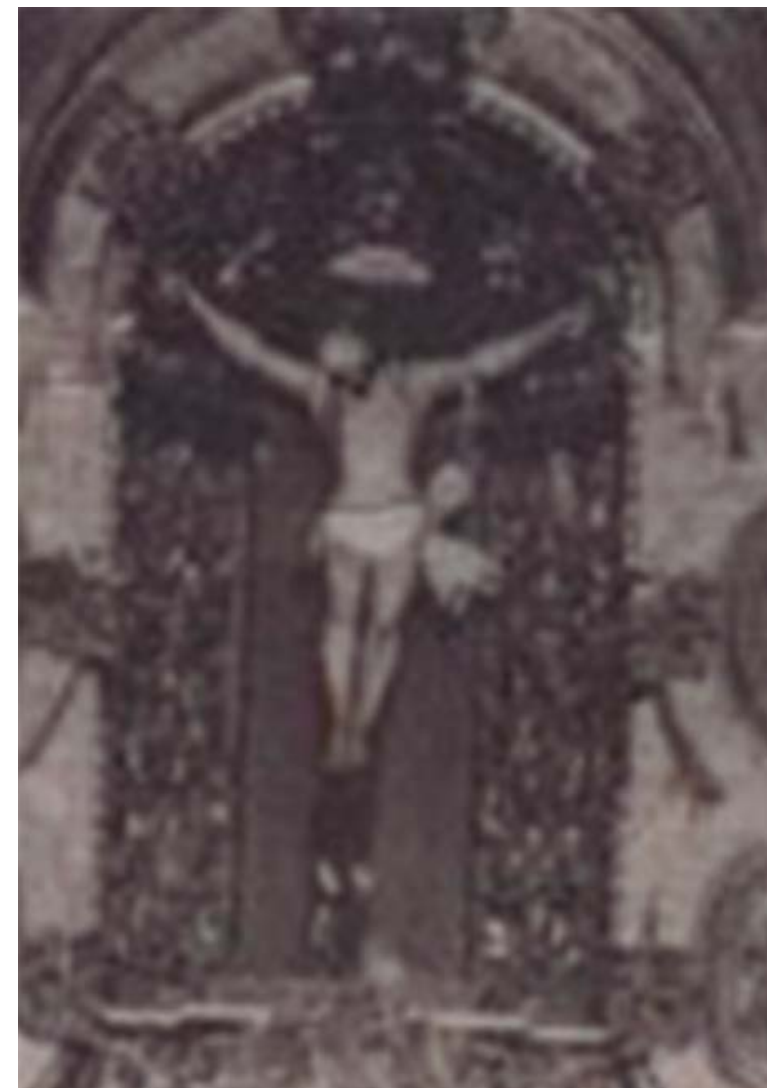

Fig. 23

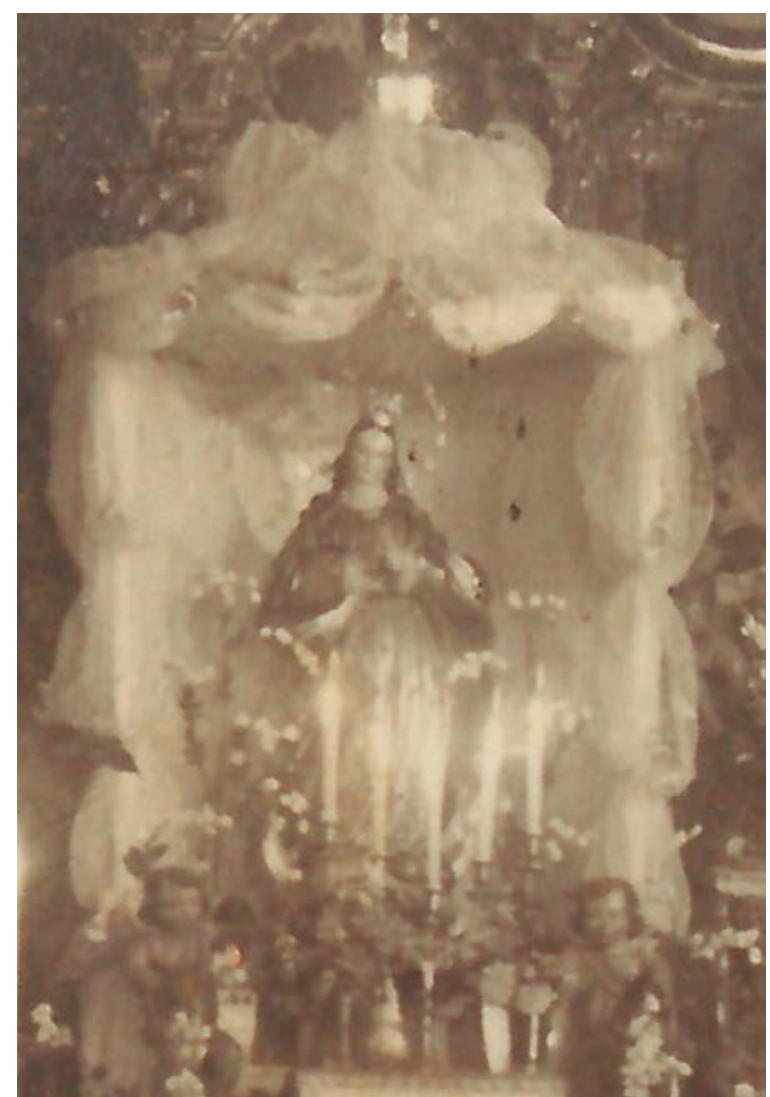

Fig. 24 


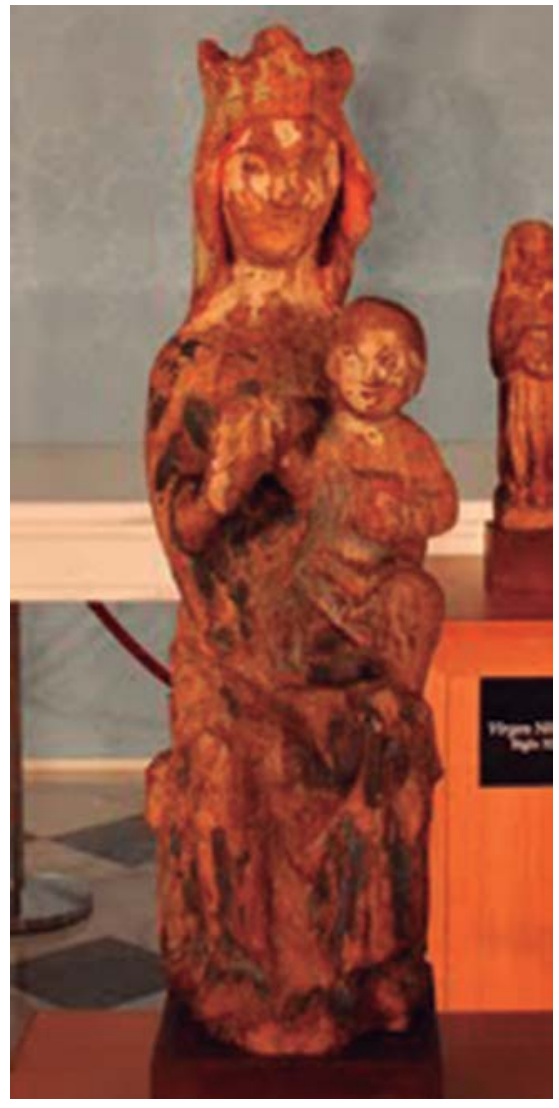

Fig. 25

(Fig. 25) Autor fotógrafo Anónimo. (Villanueva del Duque, Córdoba. Fotografía rescatada de la web a fecha de junio de 2016) Representación de Virgen de Guía.

Talla anónima del siglo XIII.

(Fig. 26) Autor fotógrafo Anónimo. (Villanueva del Duque, Córdoba. Fotografía tomada antes de la Guerra Civil) Representación de Virgen de Guía.

Talla anónima desaparecida en la Guerra Civil.

(Fig. 27) Autor fotógrafo Anónimo. (Villanueva del Duque, Córdoba. Fotografía rescatada de la web a fecha de junio de 2016) Representación de Virgen de Guía.

Actual Imagen de la Virgen de Guía realizada en 1939 por el escultor Ignacio Gómez Gil.

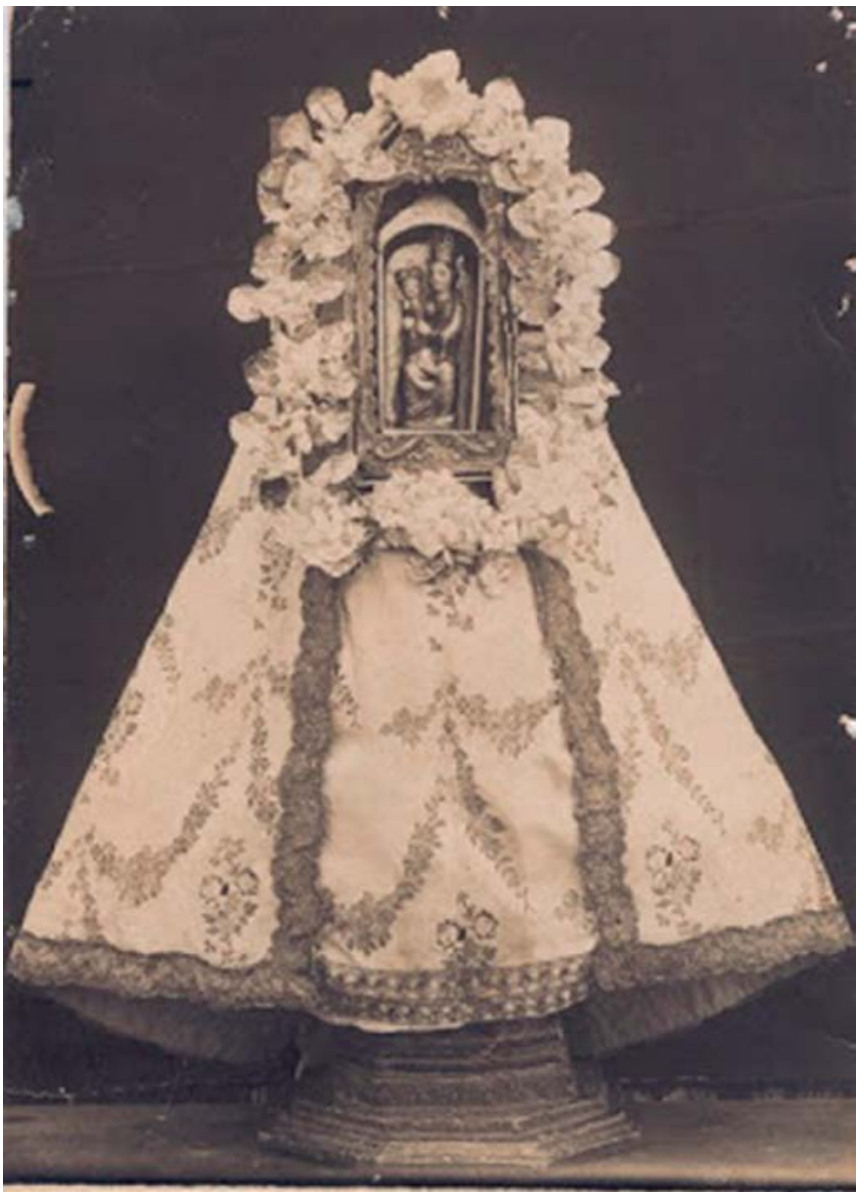

Fig. 26

(Fig. 28) Autor fotógrafo Anónimo. (Alcaracejos, Córdoba. Fotografía tomada en torno a mitad del siglo XX). Santa Bárbara.

(Fig. 29) Autor fotógrafo Anónimo. (Alcaracejos, Córdoba. Fotografía tomada en torno a mitad del siglo XX). Santa Bárbara en procesión por los mineros. 


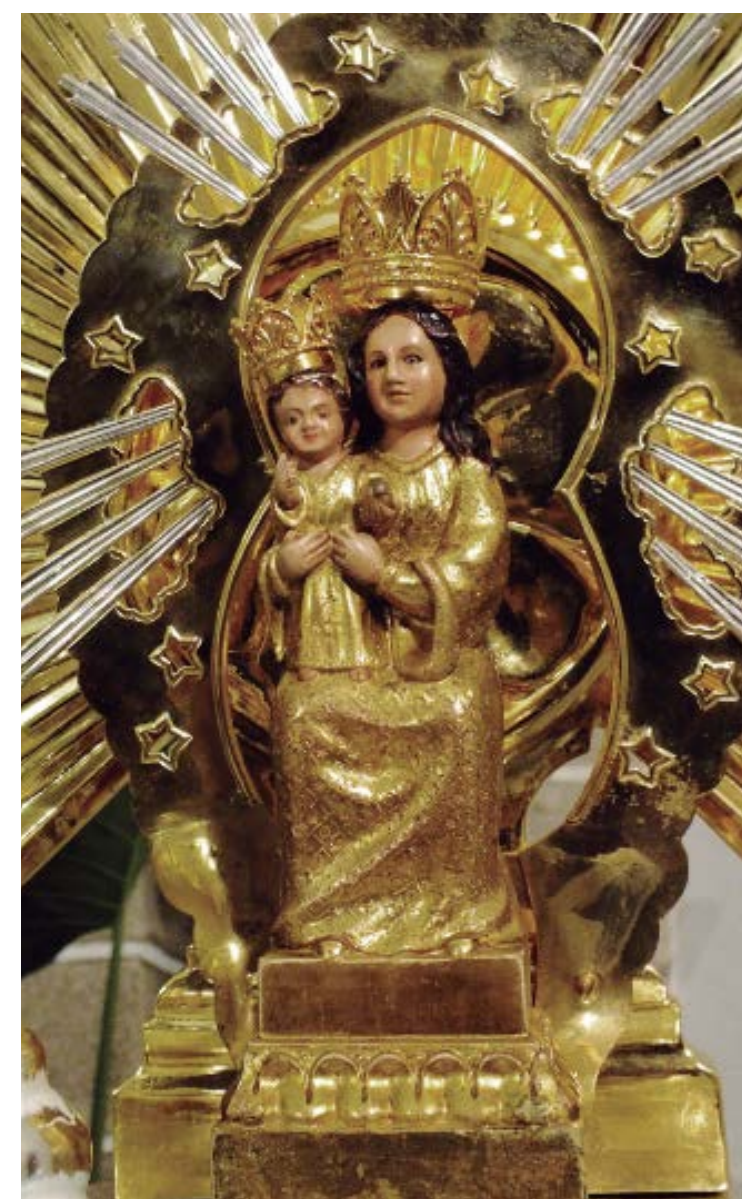

Fig. 27

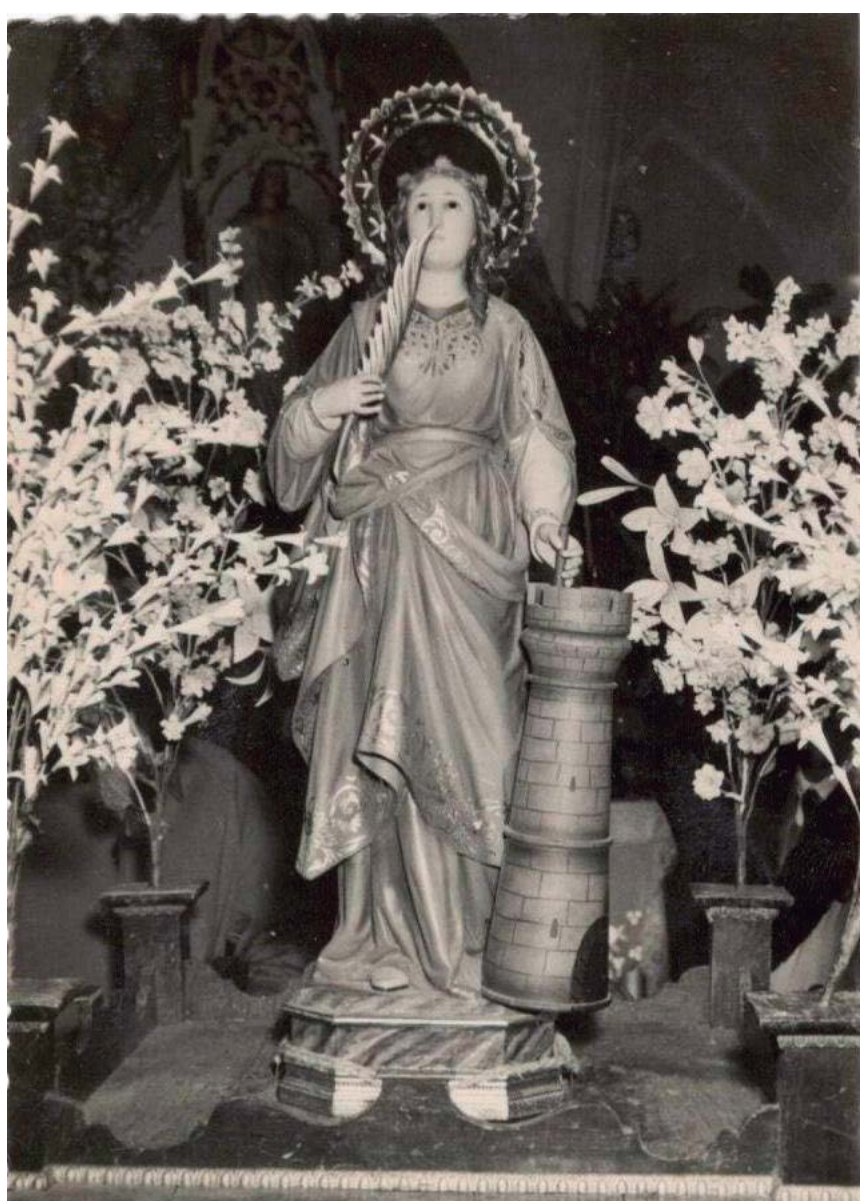

Fig. 28

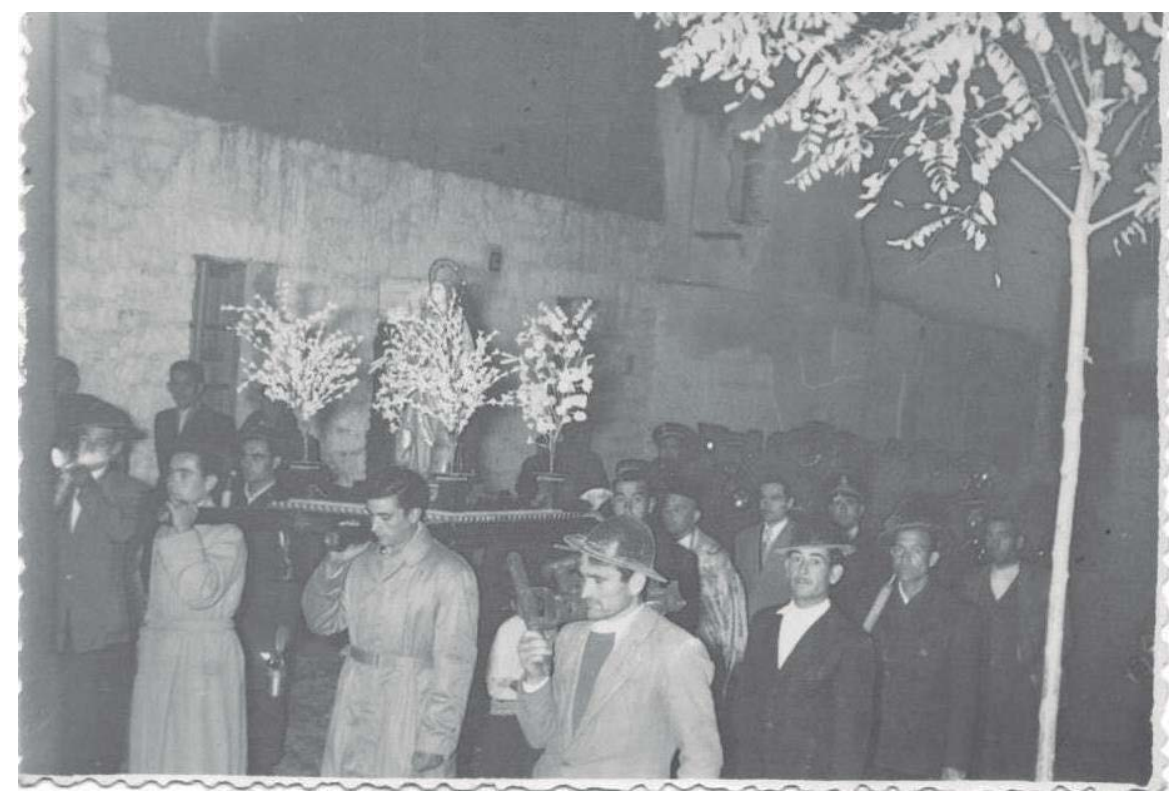

Fig. 29 



\section{El retablo mayor}

\section{$\mathrm{O}_{\text {rigen del retablo de Alcaracejos. }}$}

En el siglo XVI, en la localidad de El Viso, a diez kilómetros de Alcaracejos, se fundó un convento Franciscano de la orden Serálfica de Menores en el lugar del martirio de San Alberto del Monte. Pero la suerte de este convento llego a su fin en 1833, tras la muerte de Fernando VII. Con la aparición de la legislación liberal con la desamortización de Mendizabal y el decreto de julio de 1835, que contemplaba la supresión de dichas comunidades religiosas y que no contaran con menos de doce profesos. Así pues la comunidad abandonó en septiembre de 1835 y sus bienes fueron inventariados y posteriormente vendidos a subasta a particulares o donados a comunidades religiosas y a las parroquias más necesitadas de la diócesis de Córdoba.

De esta forma, de los seis altares del convento Franciscano, el mayor fue donado a la parroquia de Alcaracejos. En el momento el retablo contenía: un crucifijo que fue donado a Alcaracejos junto con el retablo; San Alberto, que fue donado a la parroquia de Santa Eufemia ${ }^{2}$; San Diego; San Antonio; y nuestra Señora.

(Fig. 30) Autor fotógrafo anónimo. (El Viso, Córdoba. Fotografía rescatada de la web en enero de 2016). Resto el monasterio franciscano San Alberto del Monte de El Viso.

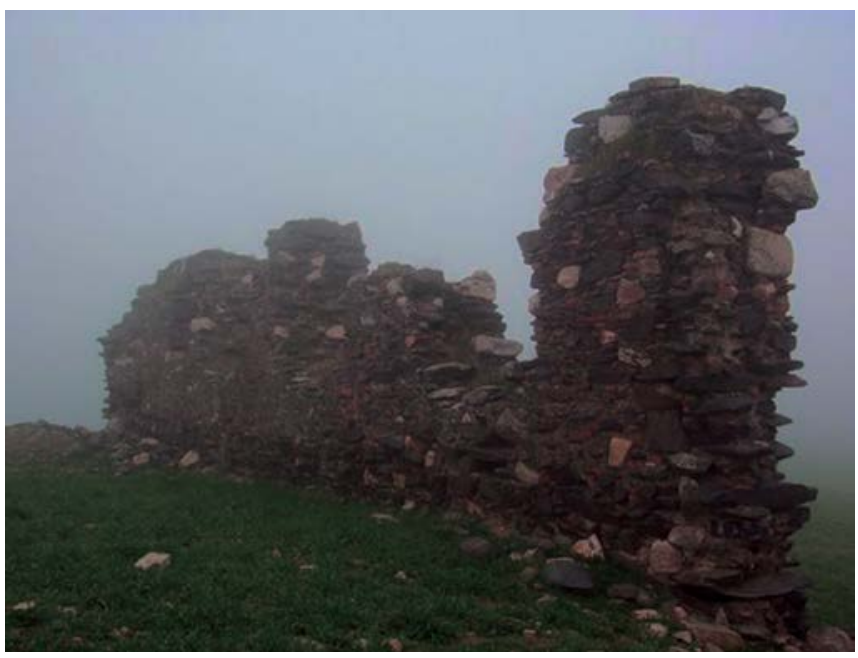

Fig. 30

1 Se puede apreciar en una de las fotografías del retablo tomadas antes de la Contienda Civil (Fig. 38, pág 61).

2 En la parroquia de la localidad de Santa Eufemia se encuentra la imagen entregada en 1840. Al igual que la localidad del Viso conserva la custodia. 


\section{El retablo mayor}

Descripción del retablo de Alcaracejos.

Ramírez de las Casas Deza ya describió el retablo de la iglesia de Alcaracejos como una obra con "muy buenos adornos de talla y pinturas nada despreciables". . Segun varias fuentes puedo saber que el retablo se encontraba en la parte Este de la iglesia, tras el altar mayor, ambos situados en el prebisterio.

Su creación se remonta entre finales del siglo XV y principios del XVI con elementos decorativos propios de un gótico muy abanzado y con influencias mudéjares. También estaban presentes piezas clásicas que a lo largo de la historia han sido empleadas independientemente del estilo y el contexto histórico en el que se hallaban. Me refiero a piezas decorativas como, capiteles coríntios y virtuosas formas geométrias o motivos florales como el lis, todos los elementos adaptados al estilo gótico tardio. También se observan elementos de incorporación barroca como columnas salomónicas, volutas y multitud de elementos ornamentales en relieve tallado.

Tal y como se describe en el Almanaque del obispado de Córdoba de 1875, podemos saber que el altar era talla dorada en pan de oro entre otros detalles:

Parroquia dedicada a San Andrés, extensa, de muy buena construcción y sólida bóveda. Su construcción es árabe, de mampostería, situada al saliente y su fachada principal mira al oeste. El altar mayor es dorado y de muy buena talla, venerándose mucho en ella una imagen de Rostro Divino. El libro de bautismos alcanza a 1554; el de matrimonios a 1578 y el de defunciones a 1615. Inmediaciones de la parroquia se halla el antiguo cementerio, que en 1842 se trasladó a la ermita de la Magdalena. ${ }^{2}$

El retablo estaba compuesto de dos calles (primer cuerpo y segundo cuerpo), dos pisos y un ático donde se encontraba la figura de un crucificado. En cuanto a la predela, se puede intuir pequeñas arcadas que, por similitud a otros retablos, se barajan dos posibles hipótesis: una de las hipótesis que deduzco es que puedan ser pequeñas puertas de acceso a la sacristía, puesto que en la época era común que ésta se encontrase en la parte trasera al prebisterio. Puedo saber que la iglesia que estamos analizando no poseía la sacristía tras el prebisterio pero, el retablo que estamos describiendo, como comenté en apartados anteriores, en su origen no pertenecía a la parroquia de San Andrés, si no a un monasterio franciscano próximo a la población. Así pues, esta primera hipótesis puede que sea probable.

Otra posible hipotesis es que fuesen falsas hornacinas como formas decorativas, sin peana ni imaginería. Esta segunda opción puede que sea la más acertada. Digo que puede que sea la más probable por las dimensiones de los arcos, por la proporción de estos con respecto al altar mayor, pues quedan a la misma altura que el altar y por tanto de imposible acceso humano hacia la sacristía.

1 RAMIREZ DE LAS CASA DEZA, L.M. Corografia histórico- estadística de la provincia y obispado de Córdoba. Córdoba, España: Monte de Piedad y caja de ahorros de Córdoba, confederación española de cajas de ahorros. P. 81 2 OBISPADO DE CÓRDOBA. (1875 (3)). Almanaque del obispado de Córdoba. Córdoba, España: publicado por diario de Córdoba. 
A su vez, estas posibles falsas hornacinas o puertas de acceso, flanquean al altar mayor que se encuentra en la parte central, adosado al retablo.

En el antiguo acto litúrgico, era común que el sacerdote de la parroquia realizase los actos consagrados de espaldas a los feligreses. Era en la parte del Evangelio, parte derecha de un prebisterio, donde ofreciese la misa cara a los beatos en latín.

Sobre el altar mayor, se puede observar varios escalones, se puede decir altares menores, también adosados al retablo junto con el altar principal, donde se sustentan diversos elementos simbólicos y decorativos de una parroquia, como por ejemplo el Sagrario.

El retablo consta de tres hornacinas principales: una central en el ático y dos en el primer piso del retablo, flanqueando el Sagrario. En la hornacina superior se encontraba un crucifijo de talla con rasgos propios del gótico tardío o renacimiento en torno al siglo XVI. Rasgos como el Paño de Pureza corto formando pliegues suaves propios del estilo clásico. El nudo queda en la parte izquierda de la figura sobresaliendo sobre la cadera; Un desnudo de piel clara y, según puede apreciarse, con escasas heridas; Se representa a Cristo con los ojos cerrados y faz serena. Rasgos faciales propios de la estética flamenca de la época; se flexiona la rodilla derecha sobre la izquierda proporcionando un aire de movimiento e intentando abandonar la rigidez. Este abandono hieratico también puede apreciarse en las manos, las cuales quedan combadas.

El crucificado que estamos describiendo posee una corona de espinas y está clavado sobre un madero con un letrero en la parte superior de forma ovalada donde aparezcan las siglas INRI. Como se puede intuir en una de las fotografías del antiguo retablo, el crucificado debía tener cuatro clavos, según la disposición de las extremidades inferiores. Con el rostro mirando hacia abajo, posiblemente estemos hablando del Cristo de la Misericordia, aunque es dificil deducir el nombre otorgado a esta figura puesto que la calidad de la imagen no nos ofrece demasiados detalles. A ambos lados del crucifijo se encontraban dos angelotes o querubines, costoso de deducir con exactitud.

Era usual que desde la baja Edad Media se representase a Cristo crucificado en el ático de un retablo, como elemento culmen de la simbología cristiana, como hombre superior ante todos los hombres y, si se da el caso, Dios padre por encima de Cristo como Ser omnipresente y celestial que todo lo observa.

En cuanto al Sagrario, es casi imposible describir cómo estaba decorado. En una de las imagenes que nos han llegado, se puede intuir una cruz griega aparentemente bordada sobre un telar que cubre la parte central. Pero como digo es simplemente una intuición. Quizás estuviese decorado con pan de oro al igual que el retablo. Lo que sí nos ha llegado es el testimonio de Ramírez de las Casas Deza afirmando que "Según las costumbres de aquellos tiempos está el Sagrario de éste altar al lado del evangelio, y por haberse hecho otro sagrario nuevo en el medio, está colocado en el antiguo un rostro divino"1. A través de esta descripción podemos deducir que el Sagrario, muy probablemente de finales del siglo $\mathrm{XV}$, fue colocado en la parte del evangelio de la iglesia que, al realizarse un nuevo Sagrario, quizás de mediados del siglo XIX, en el antiguo se colocó una figura divina y el nuevo fue ubicado en la parte central del altar mayor.

1 RAMIREZ DE LAS CASA DEZA, L.M. Corografía histórico- estadística de la provincia y obispado de Córdoba. Córdoba, España: Monte de Piedad y caja de ahorros de Córdoba, confederación española de cajas de ahorros. P. 81 
Considero que esta descripción corresponde a una de las fotografías recuperadas en la cual se observa un Sagrario decorado con dibujos simbólicos como un cáliz y el Cuerpo de Cristo en pan de oro. Sobre el Sagrario nos encontraríamos con la figura divina (tal y como señala Casas Deza), El Perpetuo Socorro $^{1}$. Se trata de una pintura que no faltaba en ningua iglesia de la época y con especial devoción en Alcaracejos, habiendo una cofradía de las hermanas del Perpetuo Socorro.

Esta advocación mariana que tanta fama tuvo en la devoción popular, proviene de las escuelas cretenses y venecianas, con el mayor representante de este modelo iconográfico Andrea Riccio de Candia.

\section{Simbología Del Perpetuo Socorro:}

La faz de la Virgen se muestra preocupada ante la aparición de los Arcángeles San Miguel a su derecha y San Gabriel a su izquierda que la flanquean, mostrando los tributos simbólicos de la Pasión de Cristo (Cruz ortodoxa, lanza y esponja). El Niño Jesús es sostenido por la mano izquierda de su madre sentado de perfil, y con la derecha cogieno sus pequeñas manos. De esta forma María se muestra como madre protectora de su hijo, mientras éste pierde una sandalia como señal de la huida precipitada. Mientras que Jesús mira hacia los Arcángeles, María mira al espectador que la contempla, con rostro pasivo pero preocupado. Su boca es pequeña como recogimiento silencioso. Ambos quedan coronados y circunscritos por una aureola que, muy probablemente fuesen añadidos posteriores al siglo XVI. Nuestra Señora porta la corona como símbolo a sus milágros y a su atribución de reina del cielo y de la Iglesia, cobrando un mayor protagonismo sobre la figura del Cristo Niño.

La imagen femenina se suele encontrar vestida con túnica naranja y manto azul oscuro ${ }^{2}$. En la parte superior del manto se representan tres estrellas situadas en la frente, como simbología de la Virginidad de María Santísima antes, durante y después del parto, al igual que las estrellas que cuelgan de su hombro. Ella es la Etrella del Mar que trajo la Luz de Luz al mundo en tinieblas.

En cuanto al fondo podemos apreciar dos pequeñas manchas de color gris oscuro flanqueando la cabeza de María. Estas dos manchas podemos intuir que son los Arcángeles mostrando los tributos de la pasión de Cristo, mientras éste los observa. El color del fondo muy probablemente fuese de color dorado con pan de oro como simbología celestial, al igual que otras representaciones de esta misma escena. En él se aprecia varias abreviaturas griegas: en la parte superior a ambos lados de la Virgen MP - OY (Madre de Dios); sobre el arcangel San Miguel OAM (El Arcangel Miguel); sobre el arcangel San Gabriel OA $\Gamma$ (El Arcangel Gabriel); junto al Niño Iç-Xç (Jesús Cristo).

Se trata de la representación de una Virgen, la cual se puede datar en el siglo XV - XVI (gótico tardío renacentista), Para la representación de estas imágenes se tomaron fuentes de estilo bizantino. El artista es desconocido.

Este icono, como ya he comentado, proviene de las escuelas de Creta y Venecia. Posiblemente el cuadro del Retablo de Alcaracejos fuese obra de un artista popular puesto que esta Virgen ha sido la advocación mariana más popular en la época. Quizás debió permanecer en el monasterio de San Alberto del Monte hasta que fue donada junto con el retablo a Alcaracejos.

\footnotetext{
1 Aunque en la imagen observamos a La Inmaculada Concepción, puedo saber que esta imagen fue colocada provisionalmente en la parte central del retablo debido a su festividad religiosa y por ello la obstentosa decoración que gira en torno a la figura (Fig. 24, pág 48).

2 Símbolo de eternidad.
} 
Estas obras están realizadas con la técnica del temple al huevo sobre tabla. Muy probablemente la obra del retablo de la iglesia de Alcaracejos, al igual que otras representaciones, también tuviera motivos decorativos con pan de oro.

Cabe citar la similitud de esta pintura en técnica y estilo con las pinturas murales al temple de la ermita de la Virgen de Guia situada en el termino de Villanueva del Duque, próximo a Alcaracejos, donde se representan a los apóstoles y a la Virgen circunscritos en aureolas doradas de estilo renacentista sin dar de lado la influencia bizantina (Fig. 29, pág. 53).

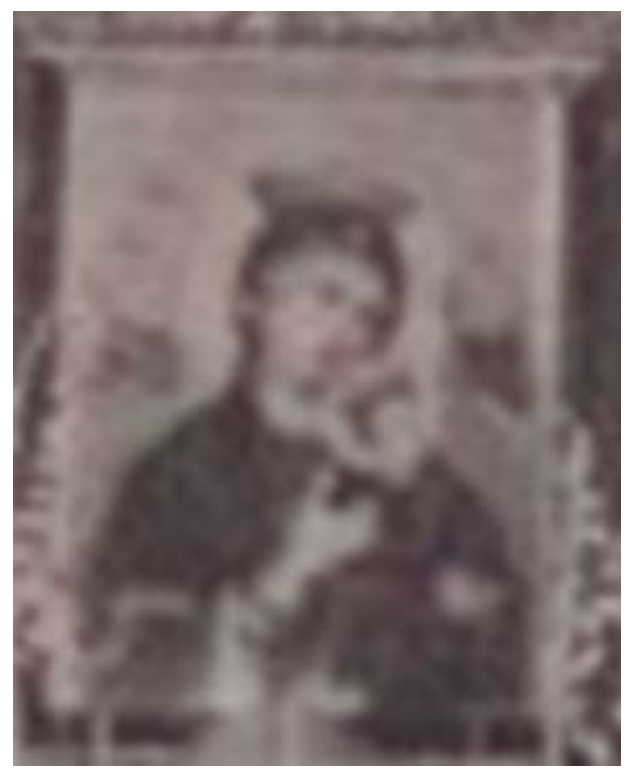

Fig. 31

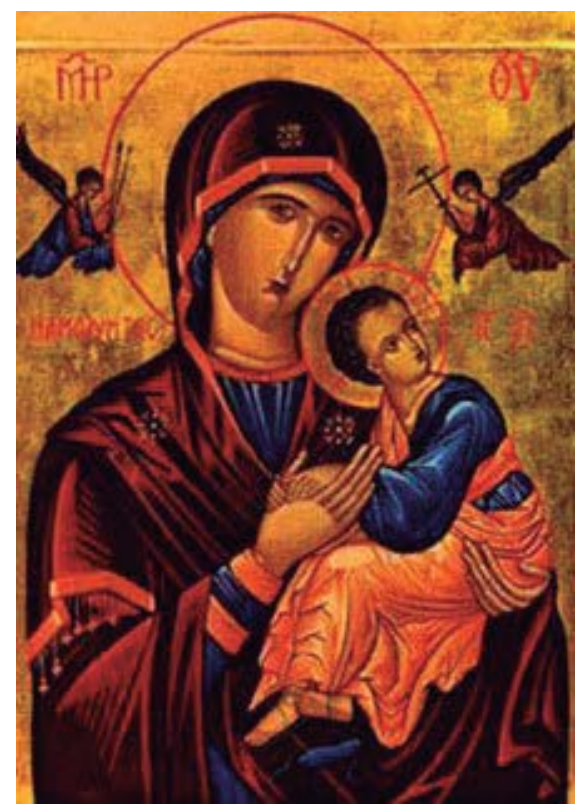

Fig. 33

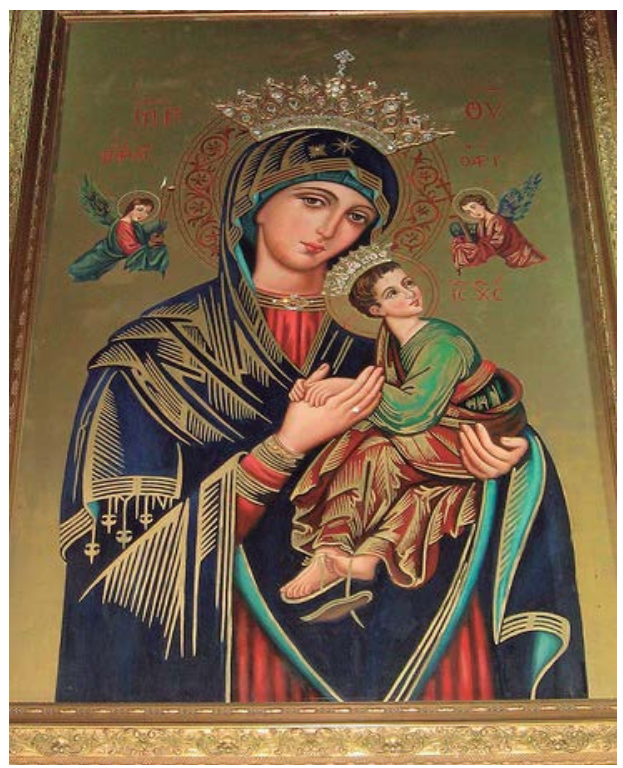

Fig. 32

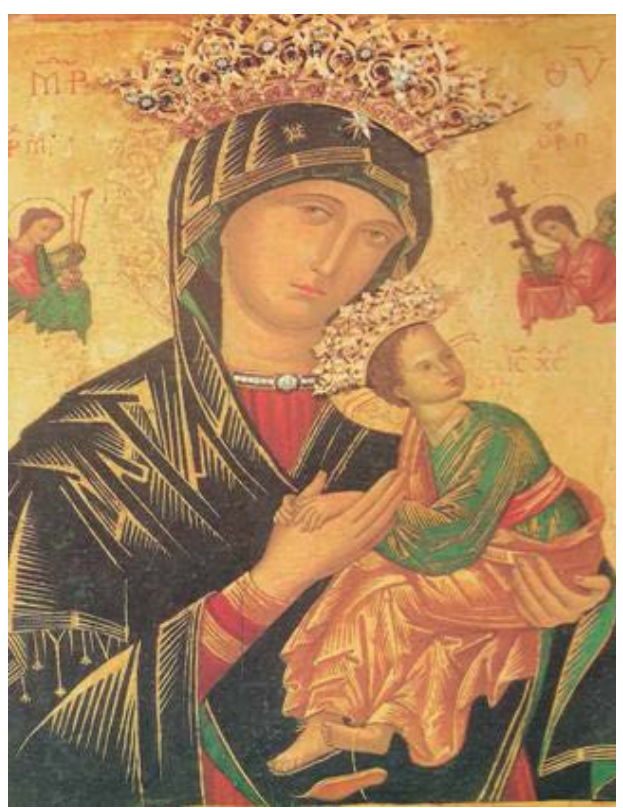

Fig. 34 
(Fig. 31) Autor fotógrafo anónimo/ autor de la obra pictórica anónimo. (Alcaracejos, Córdoba. Fotografía tomada poco antes de la Guerra Civil Española). Detalle de la Virgen del Perpetuo Socorro.

La calidad de la imagen no es muy buena debido a que se trata de una fotografía antigua y aumentada para percibir la obra pictórica dentro del conjunto del retablo.
(Figs. 32, 33, 34) Autores fotógrafos anónimos/ autores de las obras pictóricas anónimos. (Lugar desconocido, fecha desconocido). Virgen del Perpetuo Socorro.

Las imágenes están rescatadas de la web a fecha de junio de 2016.

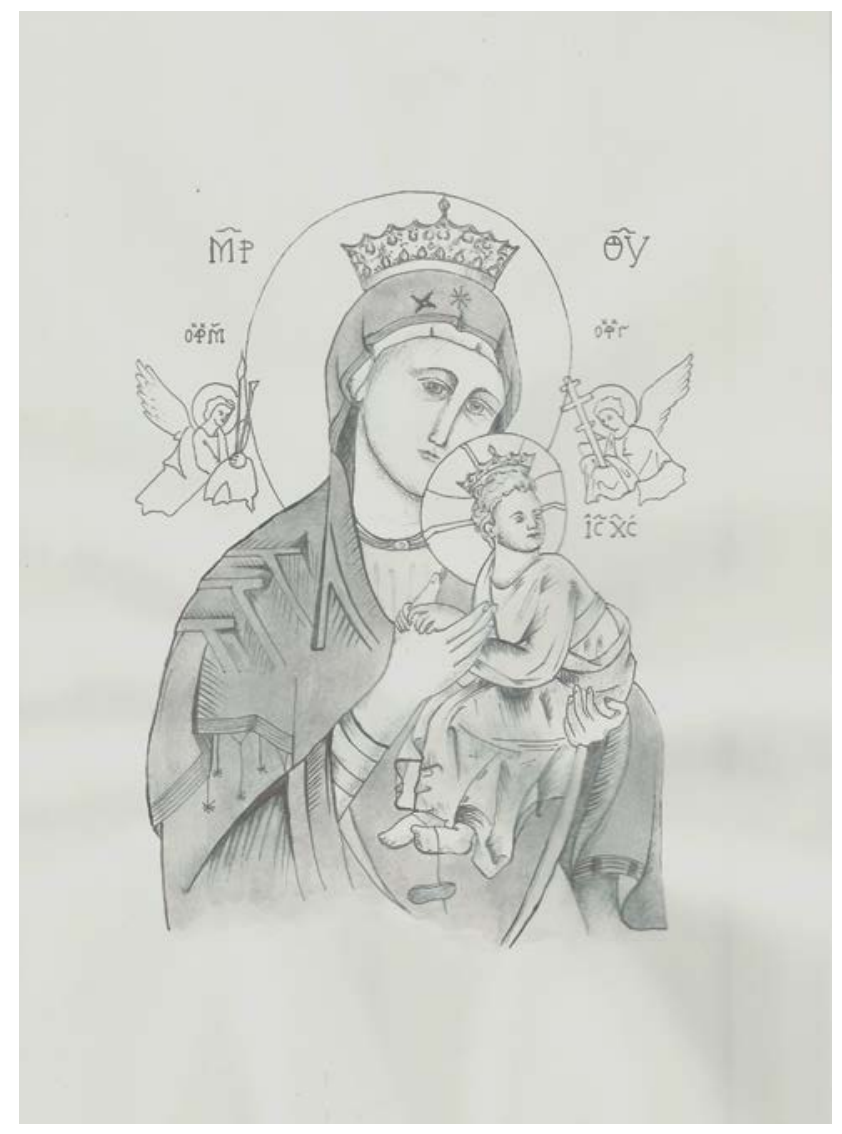

Fig. 35

(Fig. 35) Dibujo realizado por María Isabel Puerto. (Alcaracejos, Córdoba. Junio de 2016). Virgen del Perpetuo Socorro.

Boceto de Dibujo realizado a tinta con plumilla y pincel sobre papel. 


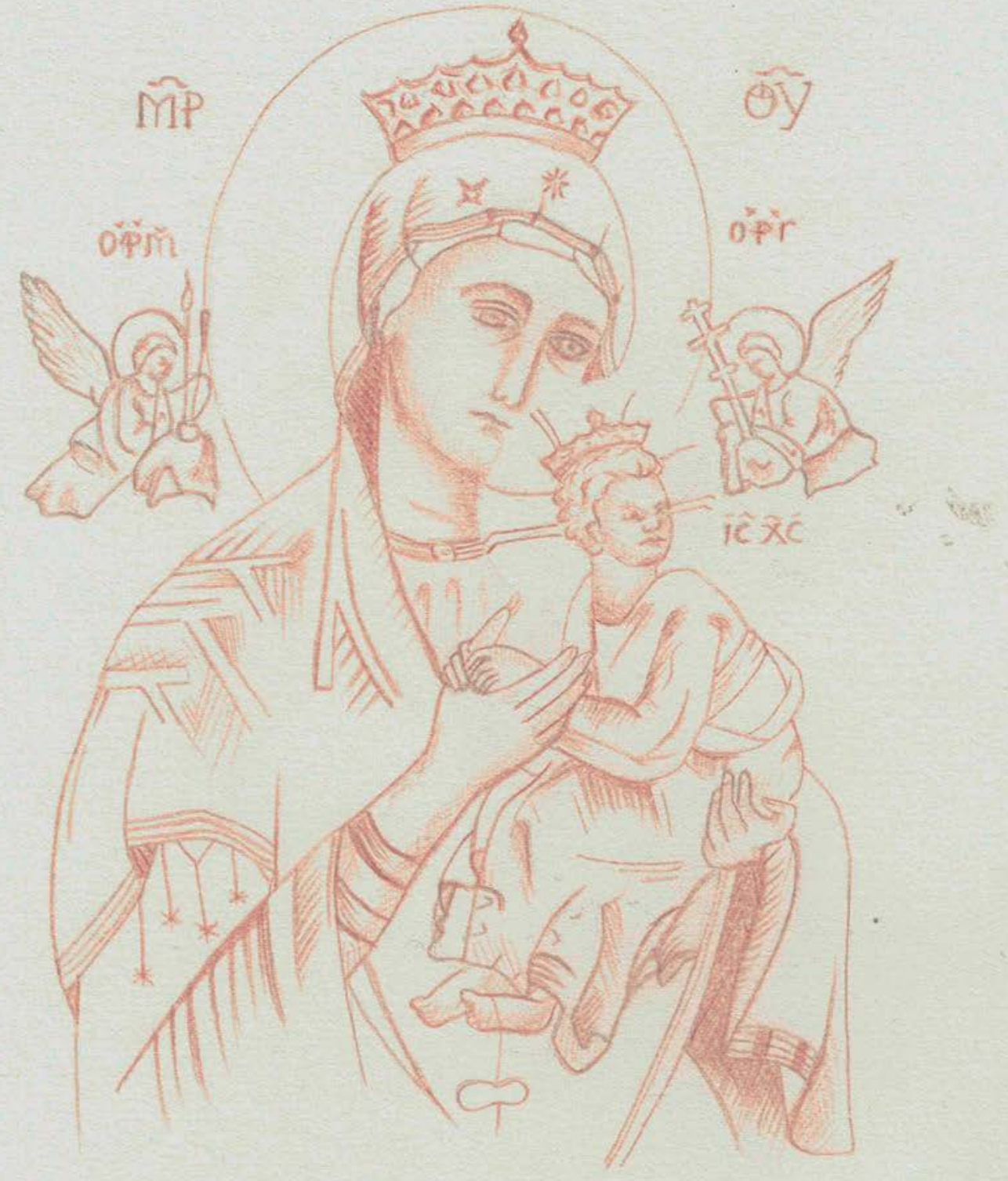

(Fig. 36) Dibujo realizado por María Isabel Puerto. (Alcaracejos, Córdoba. Junio de 2016). Virgen del Perpetuo Socorro.

Fig. 36

Dibujo realizado con sanguina sobre papel Rosa Espina. 


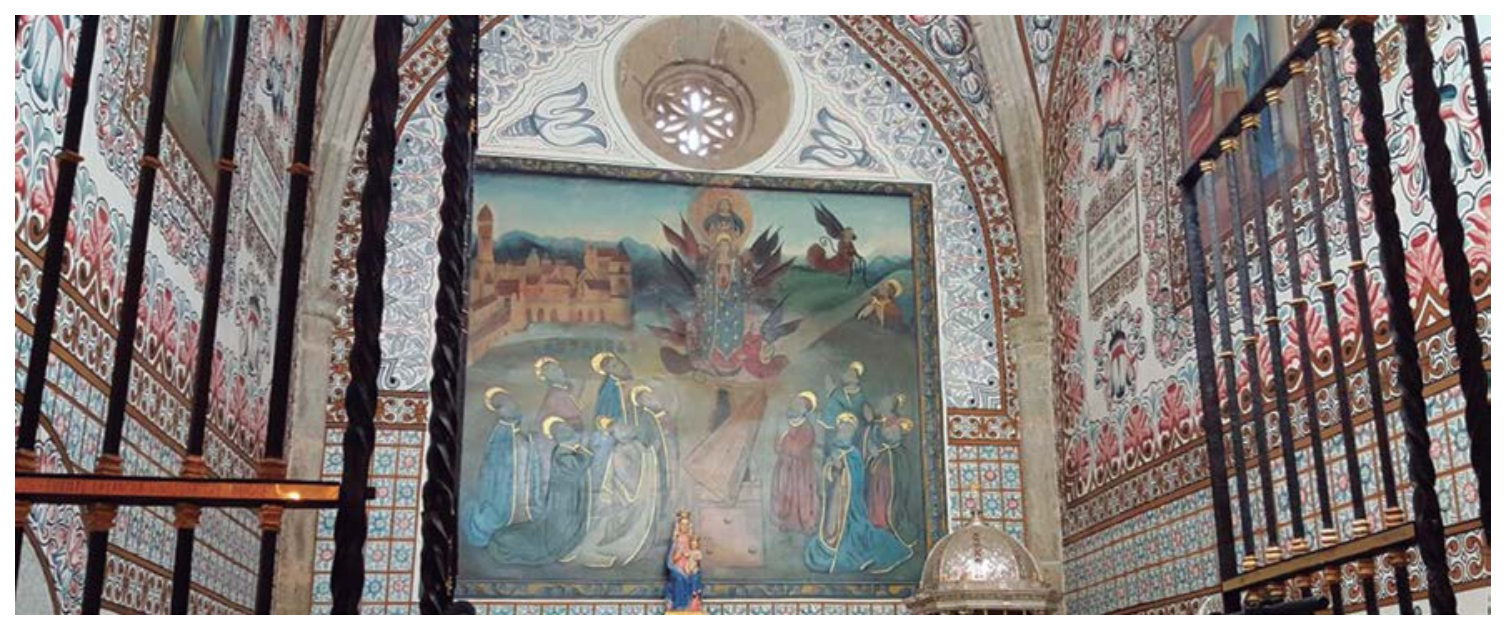

Fig. 37

(Fig. 37) Autor fotógrafo desconocido. (Villanueva del Duque, Córdoba. Rescatado de la web a fecha de mayo de 2016). Pinturas murales en ermita de la Virgen de Guía.

Observamos que entre las dos imágenes del retablo de Alcaracejos, hay diferencias. He comentado anteriormente que una de las fotografías representa el día de la Inmaculada Concepción, puesto que la figura se encuentra en la parte central del retablo y adornada con multitud de ornamentos. A pesar de la colocación de la Inmaculada en el retablo, sabemos que su lugar es una de las capillas laterales, y que en el retablo se encuentra la pintura del Perpetuo Socorro como sí apreciamos en la otra fotografía; Otra de las diferencias se encuentra en el ático del retablo. He descrito que la hornacina superior del retablo posee un crucifijo probablemente franciscano perteneciente al antiguo monasterio, lugar de origen del retablo. Pues bien, en la segunda fotografía nos encontramos con que el crucifijo ha sido sustituido por otra imagen escultórica, San Andrés, según se puede observar sus rasgos simbólicos.

No se puede pasar por alto los tejidos decorativos realizados por manos artesanas que no faltaban para vestir y embellecer un altar u otras zonas del espcio sagrado. Bordados en hilo dorado con simbología cristiana podemos observar a través de las fotografías que las hornacinas laterales anteriormente comentadas, quedan vestidas con bordados en las telas. En ocasiones, según testimonios, en dichas hornacinas laterales se colocaban imágenes escultóricas.

Es muy complicado deducir todos estos datos debido a la escas información que hay acerca de la parroquia y mucho menos aun del retablo mayor. Sólo se han conservado dos fotografías,incluso muy posiblemente las únicas que se tomaron de la parroquia puesto que estamos hablando de principios del siglo XX, cuando la cámara fotográfica sólamente la poseían las personas más acomodadas. Ambas fotografías son del mismo retablo, aunque como ya he argumentado, vestidos y ornamentados de forma diferente. 


\section{FICHA TÉCNICA.}

Tipo de arte: Retablista.

Denominación de la obra: Desconocido.

Localización: Antigua Iglesia de San Andrés en Alcaracejos, Córdoba, España.

Propietario responsable: Diócesis de Córdoba.

- Autor/ atribución: Desconocido.

- Retablista: Desconocido

- Escultores: Desconocidos

- Pintores: Desconocidos.

— Entalladores: Desconocidos.

- Policromadores: Desconocidos.

- Cronología: Origen de creación finales del siglo XV, principios del siglo XVI. Incorporaciones de estilos posteriores como renacentista, barroco y moderno.

- Materiales: Madera como soporte; revestimiento o decoración policromada con oropimente, pan de oro, aglutinantes como cola de conejo.

Policromía: En las imágenes escultóricas.

Otras Características: retablo adosado, apoyado y anclado a la pared. 


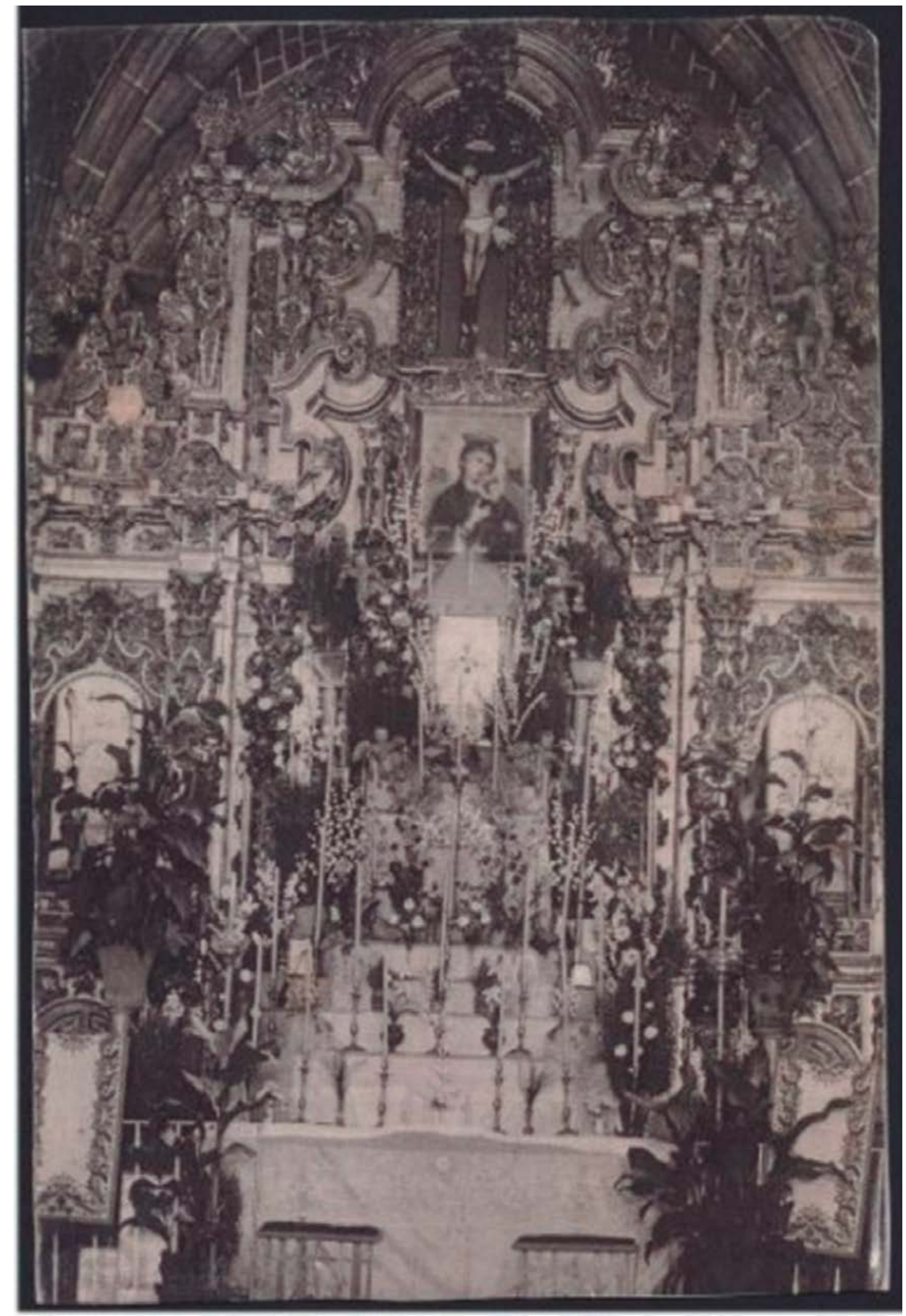

Fig. 38

(Fig. 38) Autor fotógrafo anónimo. (Alcaracejos, Córdoba. En torno a las décadas de 1920 y 1930) Retablo y altar mayor de la parroquia de San Andrés en Alcaracejos.

Vista frontal: modelo de hornamentación 1. 


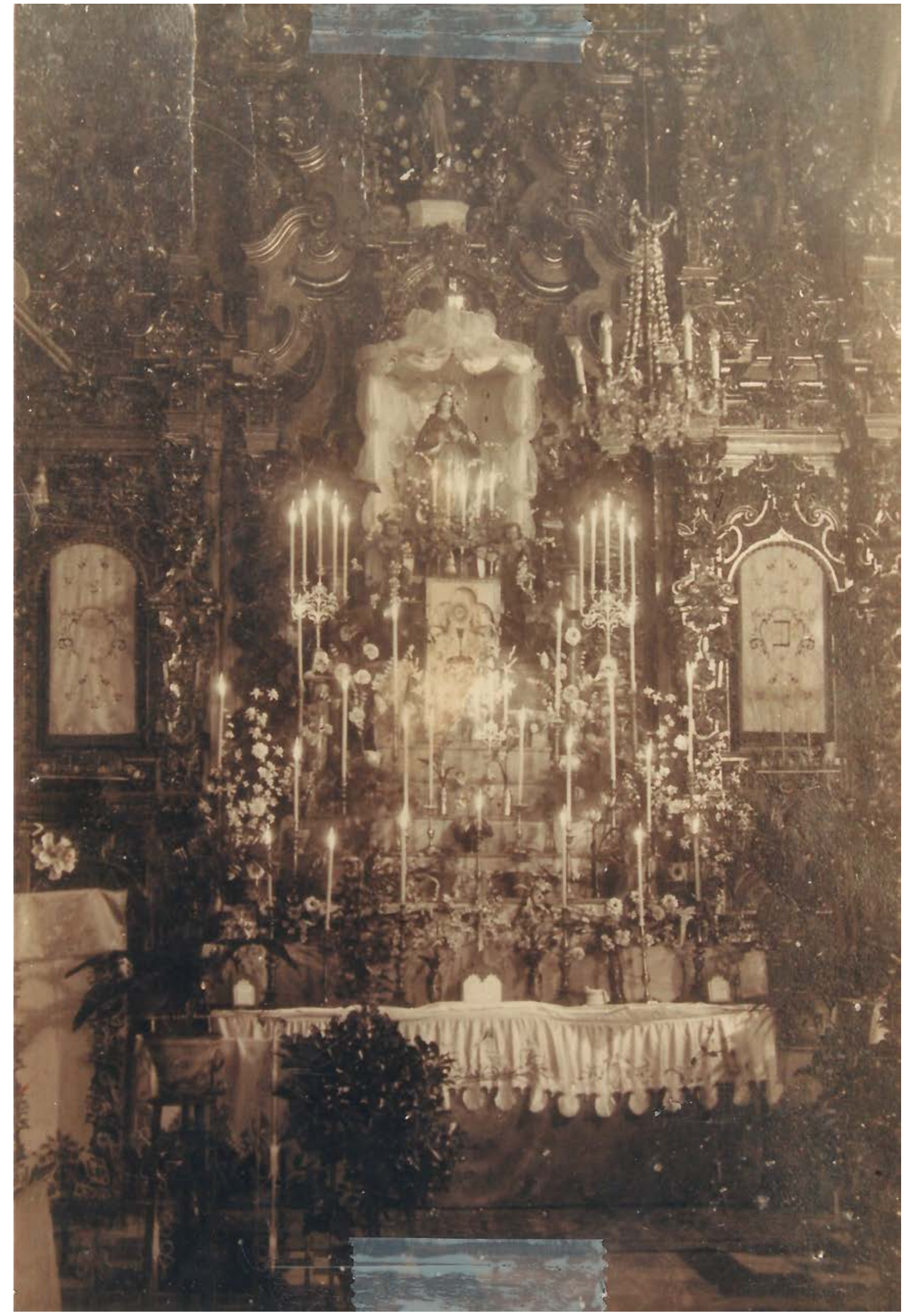

Fig. 39

(Fig. 39) Autor fotógrafo anónimo. (Alcaracejos, Córdoba. En torno a las décadas de 1920 y 1930) Retablo y altar mayor de la parroquia de San Andrés en Alcaracejos.

Vista frontal: modelo de hornamentación 2. 


\section{El retablo mayor. \\ Investigación práctica.}

Hasta el presente capítulo he argumentado todo el trabajo de investigación teórico, con una contextualización historica, artística, social y economica de cada uno de los elementos que giran en torno a la iglesia de San Andrés de Alcaracejos y en especial a su retablo (primera parte de mi investigación). Estudiada y entendida la investigación documental, pongo en práctica la segunda parte de la pesquisa, la representación gráfica del retablo mayor.

Hemos podido saber que se conservan dos fotografías del retablo al que hacemos referencia: deduzco que la imagen 38 (Fig. 38, pág 61) es más antigua que la imagen 39 (Fig. 39, pág. 62) según las descripciones anteriores. Así pues realizo un dibujo de investigación con eje principal en el modelo original del retablo, en su composición estructural, en los elementos que lo componen así como en sus esculturas y pinturas originales.

Para realizar el dibujo parto de la fotografía fig. 38, aunque es imprescindible consultar la imagen fig. 39 para mayor apreciación de detalles. Ha sido un trabajo costoso y de muchos meses de dedicación puesto que la calidad de las imagenes no permiten que percibamos demasiados detalles y sean más o menos en varias partes del dibujo una realización intuitiva. No obstante me he apoyado en descripciones sobre éste, en artistas referentes o en otros retablos cercanos a Alcaracejos o de la misma época de realización. Retablos como la iglesia de Torremilano, iglesia del Salvador de Pedroche, el retablo del convento de Santa Paula de Sevilla, los realizados por Francisco José Guerrero entre otros muchos más. 


\section{$\mathbf{P}_{\text {roceso de realización: }}$}

1. Como he citado anteriormente, la documentación ha sido primordial para poder deducir las dos imágenes del retablo que nos han llegado hasta la actualidad. Este proceso de documentación me ha permitido verificar diversos datos para posteriormente llevarlos al dibujo.

2. La observación de las fotografías es esencial. Mirar detenidamente cada detalle, analizarlo, buscar elementos en otros retablos parecidos o de la misma época para llegar a una mayor aproximación en el dibujo.

3. Tras el proceso de análisis, doy paso al dibujo en sí. Utilizando como soporte un papel de tamaño $50 \mathrm{~cm}$. de ancho por $70 \mathrm{~cm}$. de alto, con un gramaje de 300 gramos, color blanco y mate propio para el dibujo a lápiz. Sobre este papel intervengo con mina de grafito del grosor $0.5 \mathrm{~mm}$.

4. Primeramente trazo las líneas centrales, tanto la vertical como la horizontal, y a partir de ahí comienzo a encajar el dibujo partiendo de la imagen 38 (Fig. 38, pág 61) a proporción.

5. Con la ayuda de regla, escuadra, cartabón y compás, voy realizando el dibujo. Las zonas del retablo que no puedo deducir con exactitud y son una hipótesis visual propia, las realizo con mina de grafito de color azul, como elementos distintivos de las zonas que sí son exactas.

6. Al ser el retablo simétrico me ha facilitado el proceso de realización del dibujo: tras dibujar algunos elementos de la parte derecha del retablo como son las volutas del cuerpo superior, con papel vegetal y con ayuda de una mesa de luz calco el elemento, lo coloco del reverso y lo vuelvo a calcar en el soporte final.

7. En cuanto a los elementos en relieve decorativos, me he ayudado de El manual de ornamentación para dibujar algunas zonas que las fotografías no me permitian apreciar. Relieves propios de retablos con motivos florales como ojas de acanto, flor de lis, entre otras formas.

8. Por otro lado se encuentra la pintura del Perpetuo Socorro, la cual ha tenido un proceso de documentación y dibujo muy costoso: tras verificar que se trataba de la Advocación del Perpetuo Socorro, he comenzado a dibujarla. En primer lugar he recortado la fotografía del retablo en la zona que aparece la Advocación y la he aumentado de escala, imprimiéndola sobre un papel A4; una vez impreso el Perpetuo Socorro de Alcaracejos, también he impreso diferentes imágenes de la misma representación Mariana; posteriormente he superpuesto estas copias y, con una mesa de luz y un nuevo soporte, he dibujado las proporciones de la Virgen del Retablo de Alcaracejos y los elementos simbólicos de las otras copias puesto que estas se apreciaban mejor los detalles. Así obtengo el dibujo del Perpetuo Socorro en un formato A4 con la técnica de tinta china. Tras haber realizado este primer encaje, con papel rosa espina vuelvo a calcar el boceto a este soporte final, esta vez con la técnica de la sanguina. Así finalmente obtengo el dibujo de la representación Mariana como debió de ser en el retablo de Alcaracejos.

9. Una vez dibujado el Perpetuo Socorro, es escaneado digitalmente a una resolución de 600 ppp. y con la ayuda de programas de retoque de imágen es escalado hasta las medidas de 5,2 x 7,4 cm., impreso en papel y calcado gracias a mesa de luz al dibujo final del conjunto del retablo.

10. Terminada la fase de dibujo, es escaneado el dibujo $50 \times 70 \mathrm{~cm}$. y digitalizado con una resolución de 600 ppp.

11. Se aplica color digitalmente con programas de retoque fotográfico, Adobe Photoshop y se imprime con ploter al mismo tamaño que fue escaneado.

12. El resultado final son dos obras: un original en formato $50 \times 70 \mathrm{~cm}$. en grafito y una copia impresa a color del formato $50 \times 70 \mathrm{~cm}$. 


\section{$\mathrm{P}$}

roblemas tenidos en el proceso de trabajo:

1. El principal problema que he tenido en el proceso de trabajo ha sido encontrar documentación sobre la iglesia de Alcaracejos y aun más sobre el retablo del altar mayor de dicha parroquia. Al ser bombardeada la iglesia en la contienda Civil, desaparecieron todos los documentos que allí se guardaban sobre ésta, junto el el patrimonio artístico. Por ese motivo he tenido que tomar otras alternativas y lugares de investigación como son periódicos provinciales del siglo XIX y XX, archivos municipales de las localidades de Alcaracejos y sus conlindantes, archivos provinciales, y archivos eclesiásticos del Obispado de Córdoba. Pese a indagar por varios lugares, como digo la documentación es escasa o incluso nula. También destacar las trabas que el Obispado de Córdoba me ha interpuesto para poder adquirir documentación de sus archivos, por ello decidí abandonar dicho lugar y recurrir a otros lugares como bibliotecas o la web.

2. Puedo dar gracias a las personas que me han facilitado información y me han orientado en dónde poder encontrar documentos y fotografías. Por ejemplo, las fotografías de los retablos proporcionadas por vecinos de la localidad que, pese a la mala calidad de imagen, ha sido el documento que más me ha podido ayudar en la presente investigación.

3. Como digo, la mala calidad de las imagenes del retablo me han dificultado el proceso de dibujo. Uno de los problemas principales a la hora de dibujar era deducir qué elemento estaba dibujando con la mayor precisión posible. Pues bien, no llegué a ser cien por cien precisa cuando al acabar el dibujo a grafito y posteriormente entintarlo, pude darme cuenta que la Virgen que había dibujado no correspondía con la que se encontraba en el retablo. Mi dibujo representaba a la Virgen Madonna, o Virgen con el Niño pero, se trataba del Perpetuo Socorro, dato que verifiqué posteriormente en periódicos comarcales de principios del siglo XX. De este modo realicé un dibujo erroneo el cual fue utilizado como boceto para un segundo dibujo que volví a comenzar. 


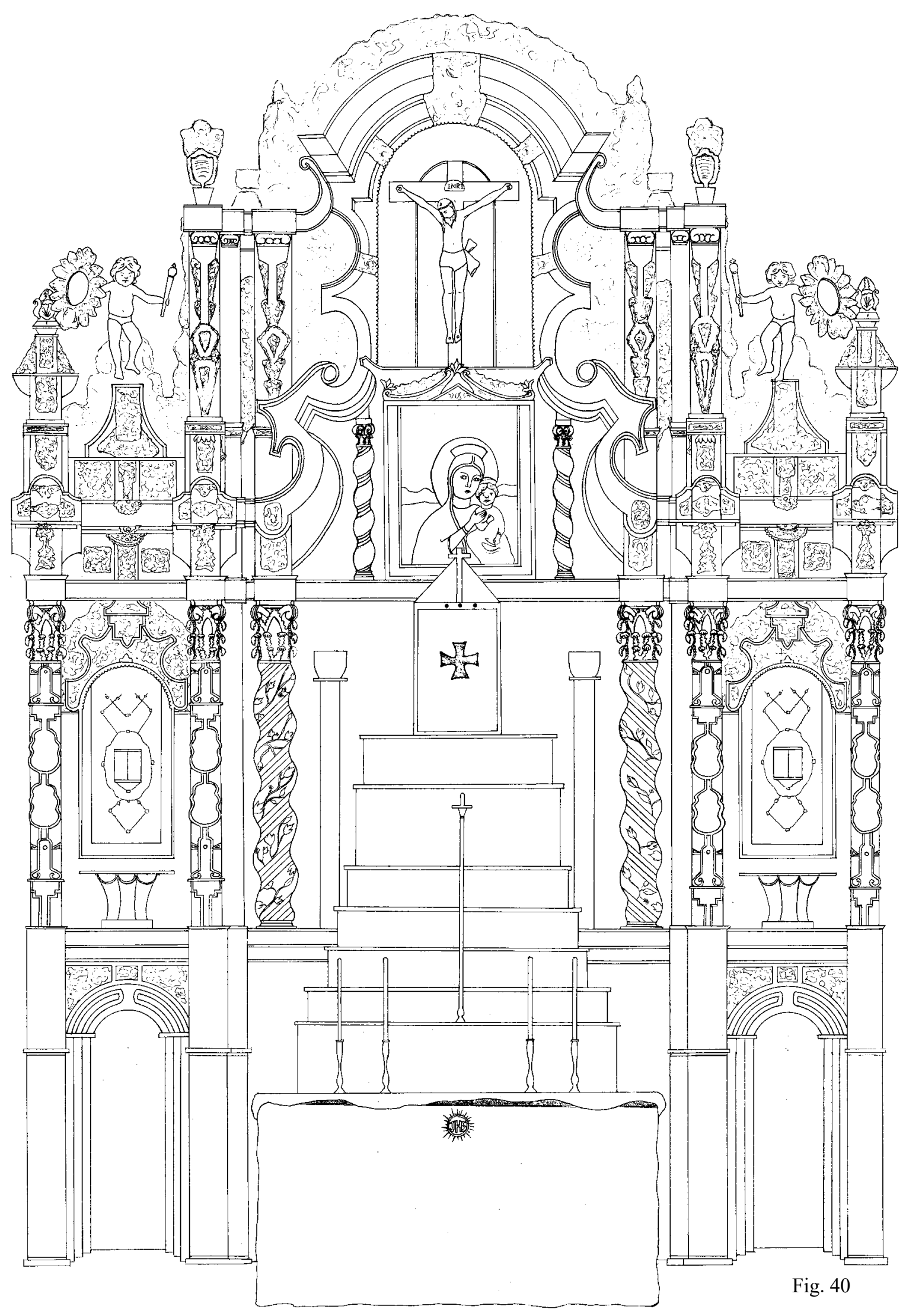

(Fig. 40) Dibujo María Isabel Puerto. (Alcaracejos, Córdoba. Marzo 2016)Retablo y altar mayor de la parroquia de San Andrés en Alcaracejos. Boceto. 


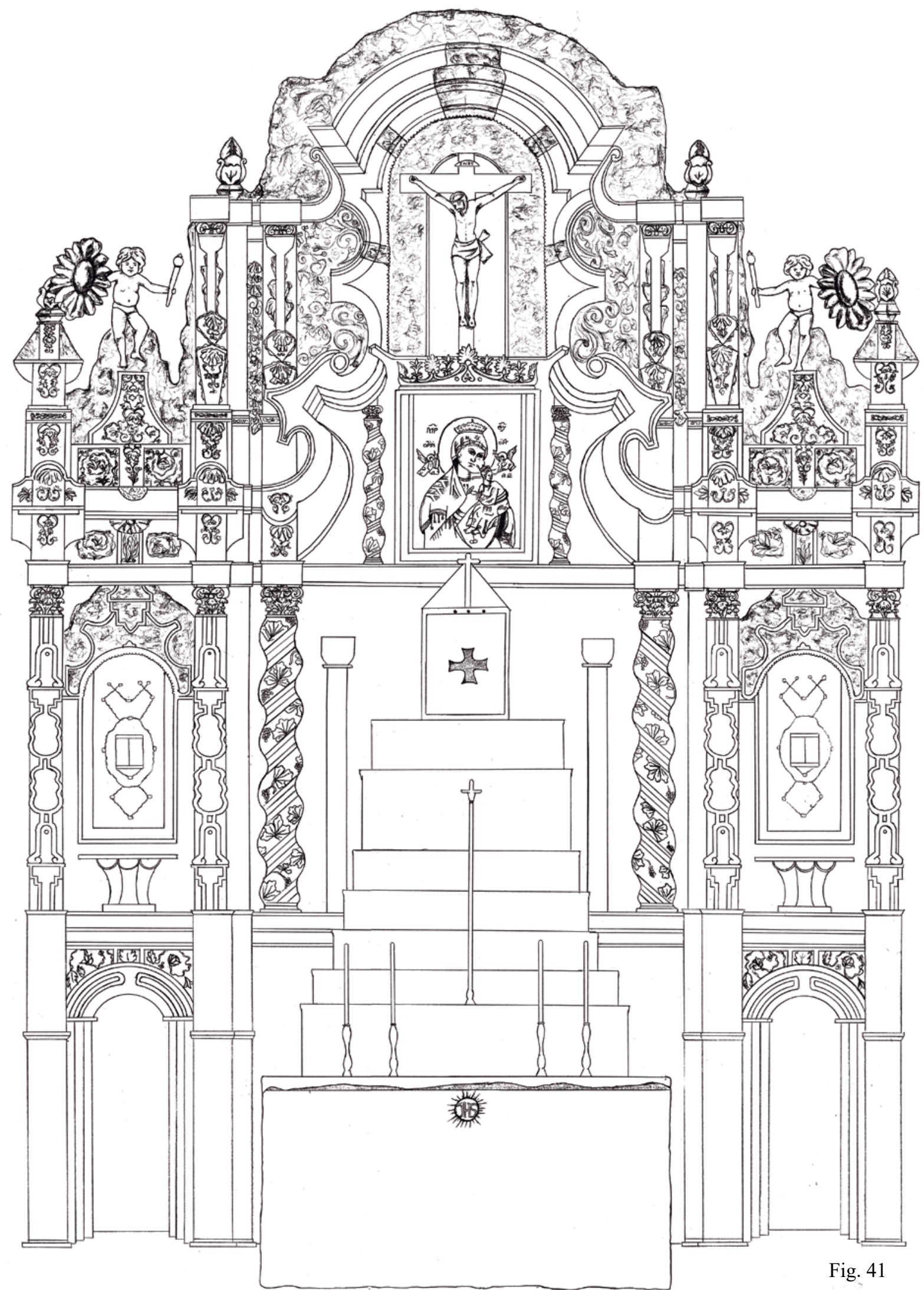

(Fig. 41) Dibujo María Isabel Puerto. (Alcaracejos, Córdoba. Marzo 2016)Retablo y altar mayor de la parroquia de San Andrés en Alcaracejos. Dibujo final, tonalidad negra. 


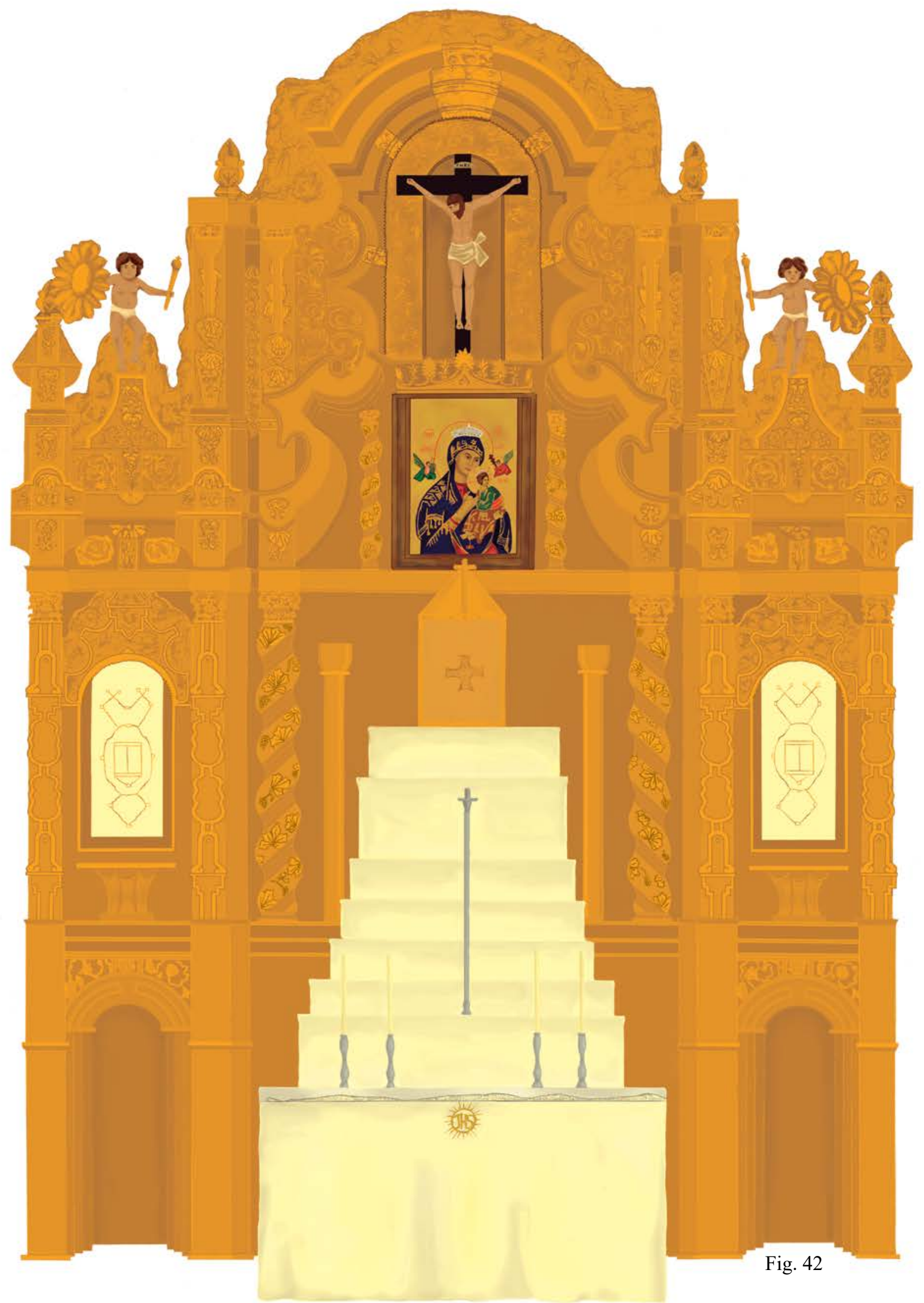

(Fig. 42) Dibujo María Isabel Puerto. (Alcaracejos, Córdoba. Agosto 2016)Retablo y altar mayor de la parroquia de San Andrés en Alcaracejos. Dibujo final, color digital. 


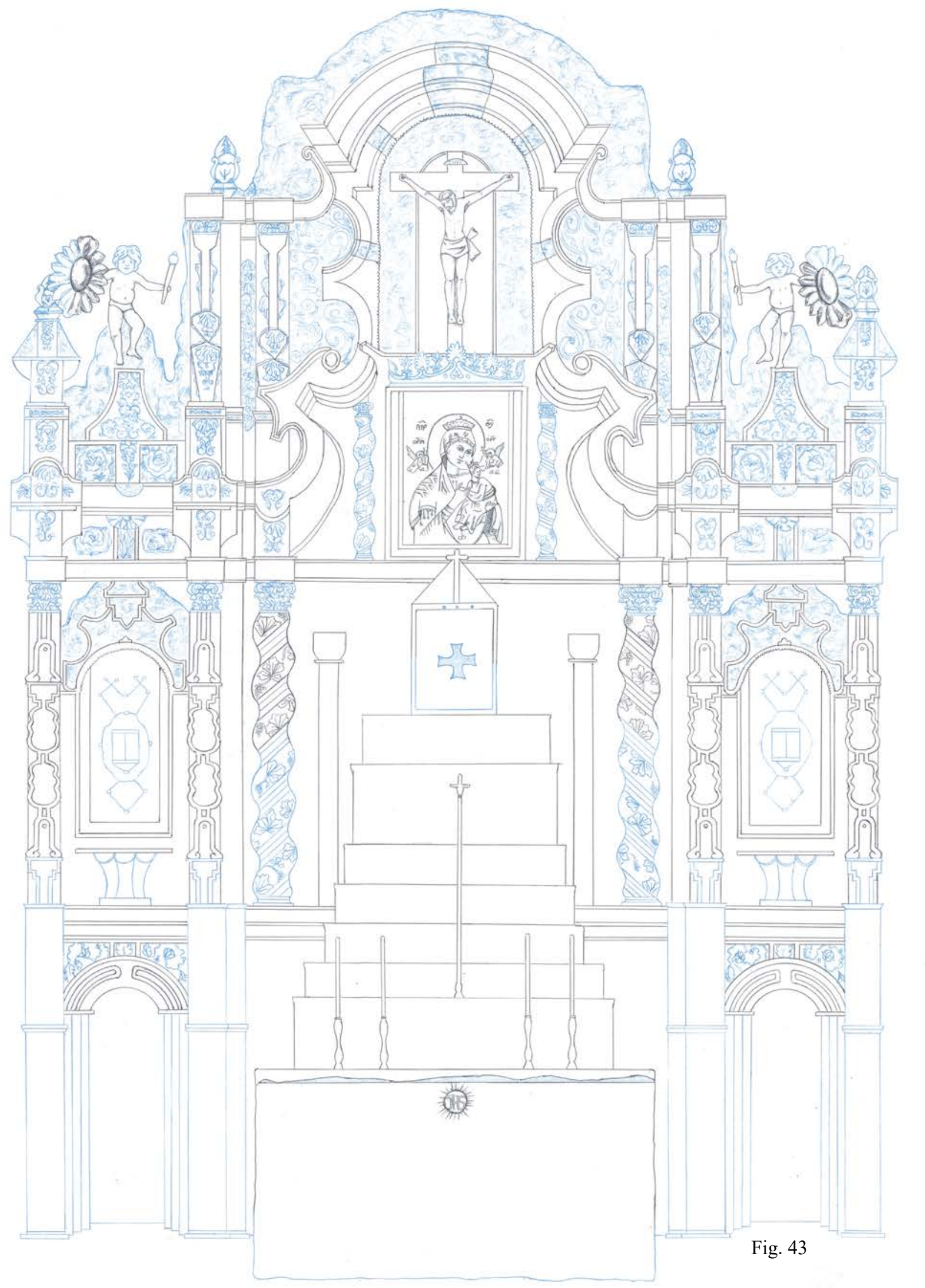

(Fig. 43) Dibujo María Isabel Puerto. (Alcaracejos, Córdoba. Julio 2016)Retablo y altar mayor de la parroquia de San Andrés en Alcaracejos. Dibujo final original: grafito negro y grafito con pigmento azul. 


\section{$\mathbf{R}_{\text {eferentes }}$}

\section{Alonso Cano}

El dibujo era una forma de expresión artística fundamental para el artista. Sus dibujos estaban cargados de expresividad guardando la elegancia y limpieza que tanto le caracteriza. Sus técnicas más usadas son la tinta y las aguadas sobre papeles verjurados principalmente en color crema. Sus dibujos eran preparación para posteriormente llevarlos a pintura, escultura e incluso retablos.

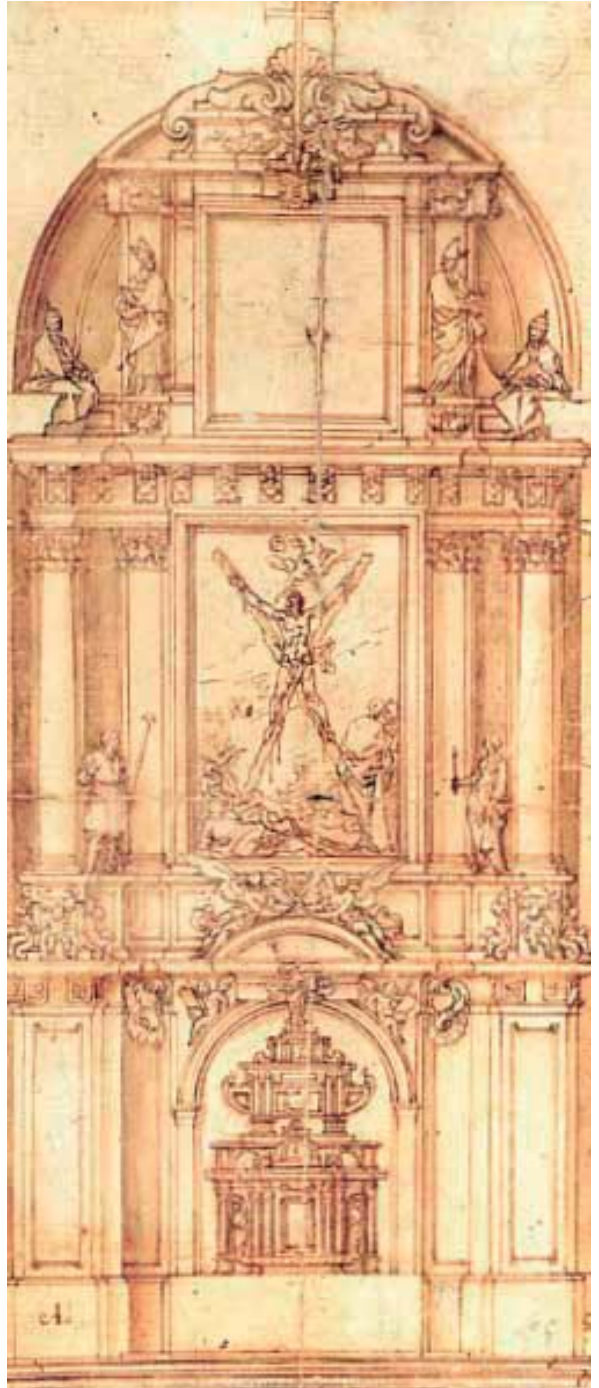

Fig. 44

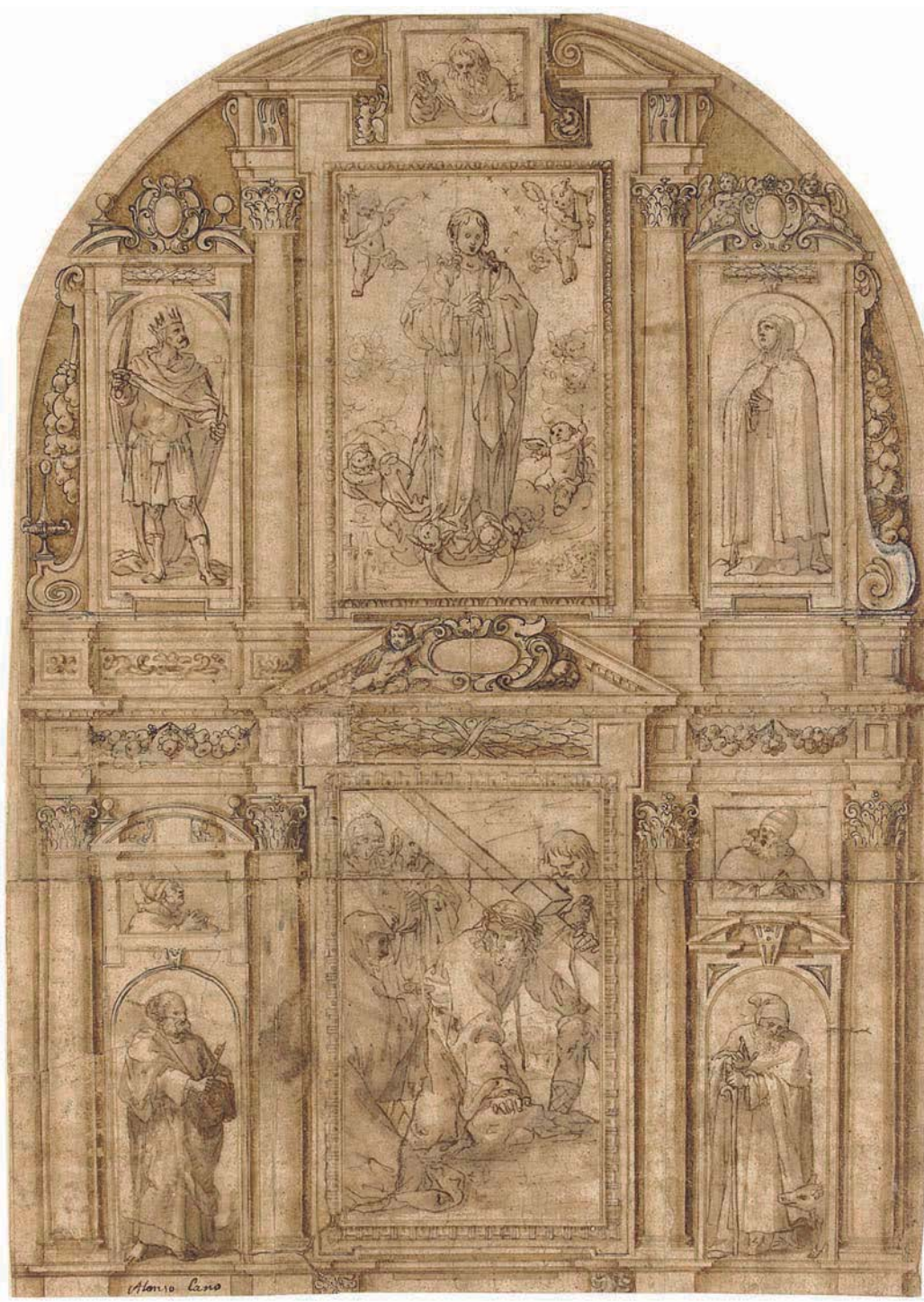

Fig. 45

(Fig. 44) Dibujo Alonso Cano. (Madrid, 1652). Retablo de Iglesia de San Andrés en Madrid.

(Fig. 45) Dibujo Alonso Cano. (Sevilla, 1635). Retablo de Iglesia de San Alberto en Sevilla. 


\section{Juan Valdés Leal}

Su obra está caracterizada por la atrocidad y el espanto. El artista estaba especializado en pintura y grabado, quizás por ello sus dibujos tengan influencia de esta disciplina gráfica, fuerte expresión y viveza en los trazos.
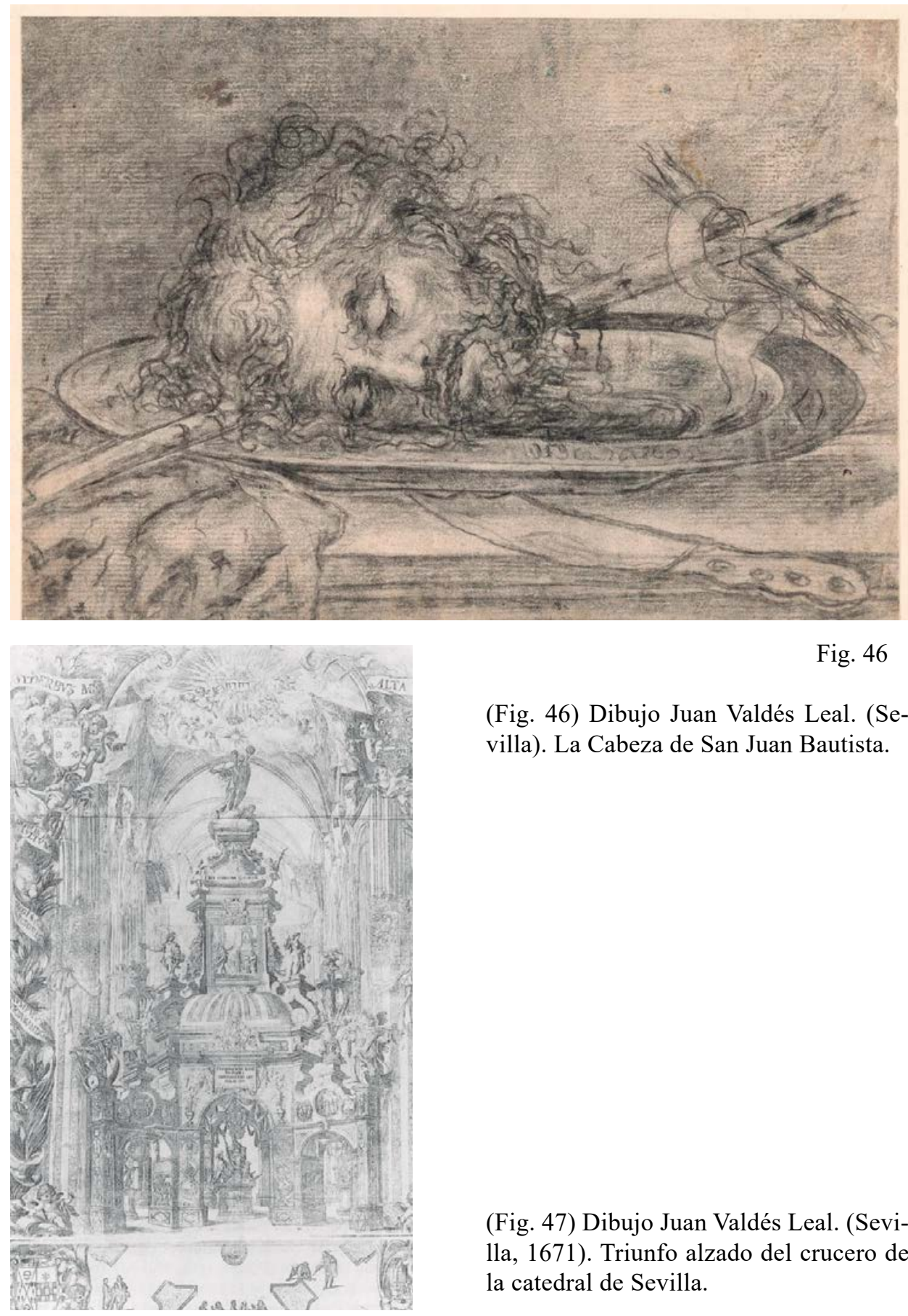

Fig. 46

(Fig. 46) Dibujo Juan Valdés Leal. (Sevilla). La Cabeza de San Juan Bautista.

(Fig. 47) Dibujo Juan Valdés Leal. (Sevi1la, 1671). Triunfo alzado del crucero de la catedral de Sevilla.

Fig. 47 


\section{Filippo Juvarra}

Obra caracterizada por los fuertes trazos abocetados, utilizando el grafito y la tinta parda sobre papel verjurado.

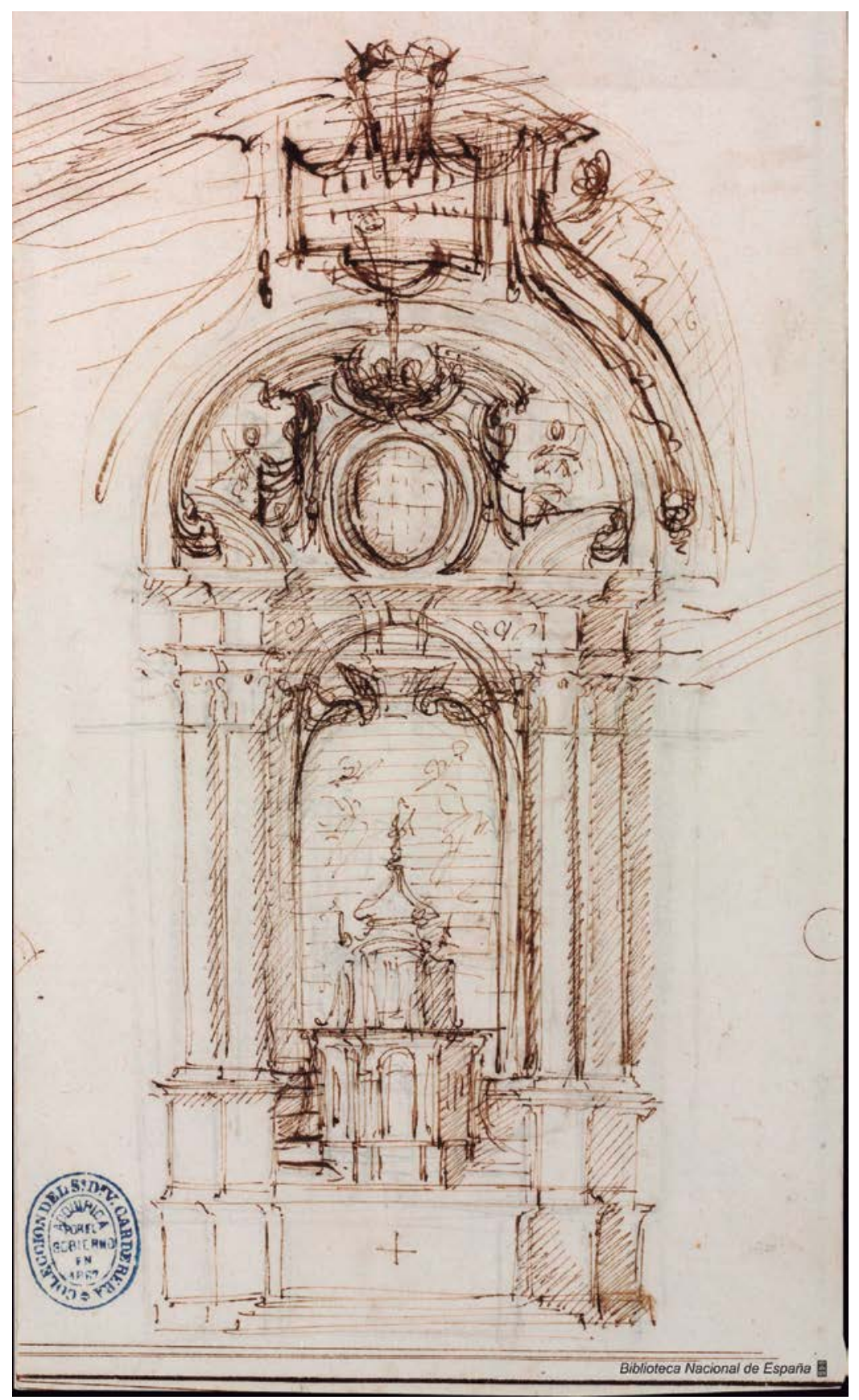

Fig. 48

(Fig. 48) Dibujo Filippo Juvarra. (1706). Proyecto de altar 
He decidido mostrar estos tres autores para mostrar tres estilos diferentes de representar dibujos de retablos. Dibujos que me han inspirado para llevar a cabo mi propio dibujo con un estilo más propio, sin olvidar las formas técnicas que ya estos antepasados estudiaron.

Estos tres artistas son sólo una pequeña muestra de todos los artistas consultados. Una plataforma que me ha ayudado para consultar dibujos de retablos es la creada por La Biblioteca Nacional. Aquí muestro la dirección web, además de en la bibliografía:

http://www.bne.es/es/Actividades/Exposiciones/Exposiciones/Exposiciones2009/dibujos/visitavirtual/obras_p1.html 


\section{Conclusión}

Gracias a toda la documentación recopilada en los diferentes archivos históricos, fuentes bibliográficas, páginas web y testimonios, he podido realizar una hipótesis visual de cómo era la desaparecida iglesia de mi localidad natal, Alcaracejos.

Puede parecer excesiva la contextualización histórica pero, para mi entender, resulta imprescindible todos estos datos para llegar a comprender de la manera más precisa posible la construcción de un edificio tan significativo como lo era una parroquia en el Medievo. Por tanto, todos estos datos me han sido primordiales para llevar a cabo mis dibujos.

Como conclusión pongo de manifiesto que el presente trabajo de investigación ha sido satisfactorio, a pesar de las dificultades anteriormente citadas, puesto que he cumplido con los objetivos marcados al comienzo de este proyecto: la reconstrucción del retablo mayor de la Parroquia de Alcaracejos antes de la Guerra Civil Española a través del dibujo como medio de expresión.

De esta forma he podido unir las dos disciplinas que más me apasionan, el arte y la historia. Poder recrear y ofrecer el patrimonio perdido a través de una de las disciplinas más importantes de las artes plásticas como es el dibujo, medio de comunicación el cual es entendible por cualquier persona en cualquier lugar del mundo. Es el dibujo al que le tengo gran pasión y al que recurro como método esencial para la realización de los proyectos de investigación.

Así pues, con la hipótesis del retablo de Alcaracejos dibujada y con una pequeña parte de documentación de lo que fue la parroquia, doy inicio a un proceso de investigación más elaborado y costoso, describir el conjunto eclesiástico de Alcaracejos antes de la Guerra Civil usando como medio el dibujo artístico.

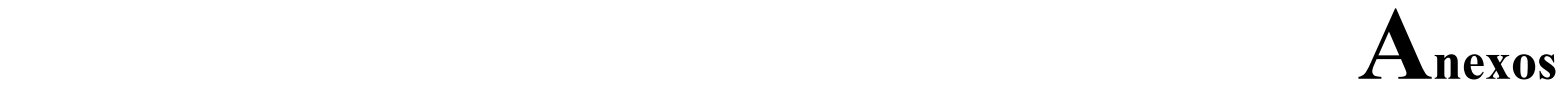

Anexo 1.

En la página 35 del presente proyecto, hago referencia a una campanilla de bronce con inscripciones en relieve Hemony Me Fecit- anno 1569, significando el año de creación de dicha campanilla y al artista creador. Pues bien, los textos encontrados en la web en los que se hace referencia a esta campanilla, página oficial del ayuntamiento de Alaracejos por ejemplo, se afirma que la campanilla contiene la inscripciónn de Emony Me Fectt-Anno , 1569. Como observamos la "H" de Hemony ha sido suprimida y en la palabra Fecit se ha confundido la "I" por la "T". Pues bien la frase Emony Me Fectt-Anno, 1569 es una interpretación erronea causada por el desgaste de dicho relieve, no significando nada. Por el contrario Hemony puede que sea el apellido del escultor mientras que Me fecit - anno 1569 el año de realización desde la traducción latín - castellano.

Con este anexo doy a otra parte de la investigación en la que he podido solucionar una malinterpretación del personal responsable de la web de Alcaracejos, o a quien corresponda, en la que se reflejan datos erroneos. 


\section{Índice de imágenes}

- (Fig. 1) Autor fotógrafo anónimo. (Alcaracejos, Córdoba. En torno a 1937). Pág. 20.

- (Fig. 2) Autor fotógrafo Anónimo. (Alcaracejos, Córdoba. En torno a 1937). Pág. 28.

- (Fig. 3) Autor fotógrafo Anónimo. (Alcaracejos, Córdoba. En torno a 1937). Pág. 29.

- (Fig. 4) Fotografía de Ma Isabel Puerto Fernández. (Hinojosa del Duque, Córdoba. Enero de 2016). Pág. 31.

- (Fig. 5) Fotografía de Ma Isabel Puerto Fernández. (Hinojosa del Duque, Córdoba. Enero de 2016). Pág. 31.

- (Fig. 6) Fotografía de Ma Isabel Puerto Fernández. (Hinojosa del Duque, Córdoba. Enero de 2016). Pág. 32.

- (Fig. 7) Fotografía de Ma Isabel Puerto Fernández. (Hinojosa del Duque, Córdoba. Enero de 2016). Pág. 32.

- (Fig. 8) Fotografía de Ma Isabel Puerto Fernández. (Hinojosa del Duque, Córdoba. Enero de 2016). Pág. 33.

- (Fig. 9) Fotografía de $\mathrm{M}^{\mathrm{a}}$ Isabel Puerto Fernández. (Hinojosa del Duque, Córdoba. Enero de 2016). Pág. 38.

- (Fig. 10) Fotografía de $M^{a}$ Isabel Puerto Fernández. (Hinojosa del Duque, Córdoba. Enero de 2016). Pág. 39.

- (Fig. 11) Fotografía de $\mathrm{M}^{\mathrm{a}}$ Isabel Puerto Fernández. (Hinojosa del Duque, Córdoba. Enero de 2016). Pág. 39.

- (Fig. 12) Fotografía de $M^{a}$ Isabel Puerto Fernández. (Hinojosa del Duque, Córdoba. Enero de 2016). Pág. 39.

- (Fig. 13) Fotografía de Ma Isabel Puerto Fernández. (Hinojosa del Duque, Córdoba. Enero de 2016). Pág. 40.

- (Fig. 14) Fotografía de $\mathrm{M}^{\mathrm{a}}$ Isabel Puerto Fernández. (Hinojosa del Duque, Córdoba. Enero de 2016). Pág. 40.

- (Fig. 15) Autor fotógrafo anónimo. (Alcaracejos, Córdoba. Fotografía tomada poco antes de la Guerra Civil Española. Pág. 40.

- (Fig. 16) Fotografía tomada por Google Maps. (Alcaracejos, Córdoba. Rescatado de la web en Junio de 2016). Pág. 41.

- (Fig. 17) Fotografía tomada por María Isabel Puerto Fernández. (Alcaracejos, Córdoba. Enero de 2016). Pág. 42.

- (Fig. 18) Fotografía tomada por María Isabel Puerto Fernández. (Alcaracejos, Córdoba. Mayo de 2016). Pág. 43.

- (Fig. 19) Fotografía tomada por María Isabel Puerto Fernández. (Hinojosa del Duque, Córdoba. Enero de 2016). Pág. 44.

- (Fig. 20) Fotografía tomada por María Isabel Puerto Fernández. (Hinojosa del Duque, Córdoba. Enero de 2016). Pág. 44.

- (Fig. 21) Autor fotógrafo anónimo. (Pedroche, Córdoba. Fotografía rescatada de la web a mayo de 2016). Pág. 44. 
- (Fig. 22) Autor fotógrafo Anónimo. (Alcaracejos, Córdoba. Fotografía tomada en torno a las décadas de 1920, principios de 1930). Pág. 48.

- (Fig. 23) Autor fotógrafo Anónimo. (Alcaracejos, Córdoba. Fotografía tomada en torno a las décadas de 1920, principios de 1930). Pág. 48.

- (Fig. 24) Autor fotógrafo Anónimo. (Alcaracejos, Córdoba. Fotografía tomada en torno a las décadas de 1920, principios de 1930). Pág. 48.

- (Fig. 25) Autor fotógrafo Anónimo. (Villanueva del Duque, Córdoba. Fotografía rescatada de la web a fecha de junio de 2016). Pág. 49.

- (Fig. 26) Autor fotógrafo Anónimo. (Villanueva del Duque, Córdoba. Fotografía tomada antes de la Guerra Civil. Pág. 49.

- (Fig. 27) Autor fotógrafo Anónimo. (Villanueva del Duque, Córdoba. Fotografía rescatada de la web a fecha de junio de 2016). Pág. 50.

- (Fig. 28) Autor fotógrafo Anónimo. (Alcaracejos, Córdoba. Fotografía tomada en torno a mitad del siglo XX). Pág. 50.

- (Fig. 29) Autor fotógrafo Anónimo. (Alcaracejos, Córdoba. Fotografía tomada en torno a mitad del siglo XX). Pág. 50.

- (Fig. 30) Autor fotógrafo anónimo. (El Viso, Córdoba. Fotografía rescatada de la web en enero de 2016). Pág. 52.

- (Fig. 31) Autor fotógrafo anónimo/ autor de la obra pictórica anónimo. (Alcaracejos, Córdoba. Fotografía tomada poco antes de la Guerra Civil Española). Pág. 56.

- (Fig. 32 Autores fotógrafos anónimos/ autores de las obras pictóricas anónimos. (Lugar desconocido, fecha desconocido). Pág. 56.

- (Fig. 33 Autores fotógrafos anónimos/ autores de las obras pictóricas anónimos. (Lugar desconocido, fecha desconocido). Pág. 56.

- (Fig. 34 Autores fotógrafos anónimos/ autores de las obras pictóricas anónimos. (Lugar desconocido, fecha desconocido). Pág. 56.

- (Fig. 35) Dibujo realizado por María Isabel Puerto. (Alcaracejos, Córdoba. Junio de 2016). Pág. 57.

- (Fig. 36) Dibujo realizado por María Isabel Puerto. (Alcaracejos, Córdoba. Junio de 2016). Pág. 58.

- (Fig. 37) Autor fotógrafo desconocido. (Villanueva del Duque, Córdoba. Rescatado de la web a fecha de mayo de 2016). Pág. 59.

- (Fig. 38) Autor fotógrafo anónimo. (Alcaracejos, Córdoba. En torno a las décadas de 1920 y 1930). Pág. 61.

- (Fig. 39) Autor fotógrafo anónimo. (Alcaracejos, Córdoba. En torno a las décadas de 1920 y 1930). Pág. 62.

- (Fig. 40) Dibujo María Isabel Puerto. (Alcaracejos, Córdoba. Marzo 2016)Retablo y altar mayor de la parroquia de San Andrés en Alcaracejos. Pág. 66.

- (Fig. 41) Dibujo María Isabel Puerto. (Alcaracejos, Córdoba. Julio 2016)Retablo y altar mayor de la parroquia de San Andrés en Alcaracejos. Pág. 67.

- (Fig. 42) Dibujo María Isabel Puerto. (Alcaracejos, Córdoba. Agosto 2016)Retablo y altar mayor de la parroquia de San Andrés en Alcaracejos. 68 
- (Fig. 43) Dibujo María Isabel Puerto. (Alcaracejos, Córdoba. Julio 2016)Retablo y altar mayor de la parroquia de San Andrés en Alcaracejos. Pág. 69.

- (Fig. 44) Dibujo Alonso Cano. (Madrid, 1652). Pág. 70.

- (Fig. 45) Dibujo Alonso Cano. (Sevilla, 1635). Pág. 70.

- (Fig. 46) Dibujo Juan Valdés Leal. (Sevilla). Pág. 71.

- (Fig. 47) Dibujo Juan Valdés Leal. (Sevilla, 1671). Pág. 71.

- (Fig. 48) Dibujo Filippo Juvarra. (1706). Pág. 72. 


\section{Bibliografía}

Libros, Revistas y prensa

- ARCÁNAGA RAVÉ, Julio. (24 de febrero de 1913). Crónica de Alcaracejos. La Santa Misión. El defensor de Córdoba: diario católico, año 15 ( $\mathrm{n}^{\circ}$ 4092). Córdoba. Pp. 11.

- CABRONERO Y ROMERO, Manuel. (1891 - 1892). Alcaracejos. Guía de Córdoba y su provincia para 1891 y 1892. Córdoba. Pp. 345 -347.

- CORRESPONSAL DESCONOCIDO. (20 de mayo de 1910). Alcaracejos. Diario de Córdoba de comercio, industria, administración, noticias y avisos, año 61. (nº 18348). Córdoba. Pp. 1.

- CORRESPONSAl DESCONOCIDO. (23 de abril de 1909). Alcaracejos. Diario de Córdoba de comercio, industria, administración, noticias y avisos, año 60. (nº 17959). Córdoba. Pp. 2.

- CORRESPONSAL DESCONOCIDO. (29 de julio de 1933). De Alcaracejos. El cronista del Valle $\left(\mathrm{n}^{\mathrm{o}}\right.$ 1.220). Pozoblanco. Pp. 2

- CORRESPONSAL DESCONOCIDO. (30 de julio de 1919). Alcaracejos. El defensor de Córdoba: diario católico, año 21. ( $\mathrm{n}^{\circ}$ 6081). Córdoba, Pp. 4

- CORRESPONSAL DESCONOCIDO. (7 de octubre de 1924). De Alcaracejos, el Santo Rosario. El defensor de Córdoba: diario católico, año 26. (nº 8114). Córdoba, Pp. 4.

- CORRESPONSAL DESCONOCIDO. (diciembre de 1923). La devoción a la Inmaculada en Córdoba y su provincia. Revista mariana: publicación mensual con censura eclesiástica dedicada a fomentar la devoción a la Santísima Virgen, año 1. (nº 4). Córdoba. Pp. 47.

- DE LAS CASA DEZA, L.M. (1841). Breve tratado de geografia de la provincia de Córdoba para uso de los colegios y escuelas por Don ***. Córdoba, España: Imprenta de García.

- DE LAS CASA DEZA, L.M. (1866). Descripción de la Iglesia Catedral de Córdoba. Córdoba, España: Imprenta de Rafael Rojo.

- DE LAS CASA DEZA, L.M. (1986). Corografía histórico - estadística de la provincia y obispado de Córdoba. Córdoba, España: Monte de Piedad y caja de ahorros de Córdoba, confederación española de cajas de ahorros.

- DESCONOCIDO. (1926). Anales de la comisión Provincial de Monumentos Históricos y Artísticos. Córdoba, España: imprenta Hospicio. Pp. 73

- DESCONOCIDO. (Octubre 2014). Bienes, paisajes e itinerarios. El patrimonio arquitectónico en la Comarca de los Pedroches. Revista Ph. (86), pp. $34-44$.

- DESCONOCIDO. (Octubre 2014). Bienes, paisajes e itinerarios. Las rutas culturales de los Pedroches. Revista Ph. (86), pp. 50 - 59.

- ECO, Umberto. (1993). Cómo se hace una tesis doctoral. Barcelona, España: Gedisa.

- ESPINALT, Bernardo. (1787). Villa de Alcaracejos. Atlante Español. Madrid, España: Imprenta de González, pp. 123 - 125. 
- ESTRADA, Juan Antonio. (1768). Población general de España. Madrid, España: Imprenta de Andrés Ramírez. Pp. 456.

- FOUQUET, Jean. (30 de marzo de 1937). Agence Espagne: informaions télégraphiques et téléphoniques de dernière heure $\left(\mathrm{n}^{0} 77\right)$. París.

- GARCIA LOVERA, Juan A. (26 de febrero de 1930). La voz en Alcaracejos. La voz: diario gráfico de información, año 11 ( $\mathrm{n}^{\circ}$ 3817). Córdoba. Pp. 12

- GARCIA LOVERA, Juan A. (7 de octubre de 1924). De Alcaracejos. La voz: diario gráfico de información, año 5 ( ${ }^{\circ}$ 1704). Córdoba. Pp. 11.

- GARCIA LOVERA, Juan A. (8 de octubre de 1924). De Alcaracejos, del Santo Rosario. La voz: diario gráfico de información, año 5 (nº 1705). Córdoba. Pp. 15.

- GARCIA LOVERA, Juan A. (9 de octubre de 1925). Desde Alcaracejos, la Virgen del Rosario. La voz: diario gráfico de información, año 6 (n 2042). Córdoba. Pp. 7.

- GARCIA LOVERA, Juan A. (diciembre de 1929). Alcaracejos. La voz: diario gráfico de información, año 10. (nº 3749). Córdoba. Pp. 6.

- GIL MUÑIZ, Alfredo. (1925). El Valle de los Pedroches. Boletín de la Real Academia de Córdoba. Córdoba, España: Real Academia de Córdoba. Pp. 131- 167.

- GÓMEZ GARCÍA, Carmen. (2007). Disposición del paño de pureza en la escultura del Cristo crucificado entre los siglos XII y XVII. Madrid, España: Universidad complutense de Madrid.

- LOPEZ NAVARRETE, José. (1988). Recopilación de datos sobre Alcaracejos y sus Costumbres. Alcaracejos, España: Ayuntamiento de Alcaracejos.

- MADOZ, Pascual. (1845-1850). Diccionario geográfico- estadístico- histórico de España y sus posesiones de ultramar. Madrid, España. Pp. $424-425$.

- MARQUEZ TRIGUEROS, Esteban. (1995). Iglesias medievales del Valle de los Pedroches. Córdoba, España: Publicaciones de la obra Cultural del grupo de empresas P.R.A.S.A.

- MÉNDEZ SYLVA, Rodrigo. (1675). Población general de España. Madrid, España. Pp. 204.

- MERINO MADRID, Antonio. (2001). Las siete villas de los Pedroches a finales del siglo XVIII según el Atlante Español de Bernardo Espinalt. Córdoba, España: Crónica de Córdoba y sus pueblos VI, Asociación Provincial Cordobesa de Cronistas Oficiales y Excma. Diputación Provincial de Córdoba. Pp. 357- 365.

- MEYER, F.S. (1994). Manual de ornamentación. Barcelona, España: Gustavo Gili.

- MOLINERO, J.A. (2005). La iglesia parroquial de Santiago Apóstol de Torrefranca. Dos Torres, España: Ayuntamiento de Dos Torres.

- MOLinero, J.A. (2006). Iglesia parroquial de Ntra. Sra. de la Asunción de Dos Torres. Dos Torres, España: Ayuntamiento de Dos Torres.

- MOLINERO, J.A. (2008). Villanueva del Duque: patrimonio monumental y artístico. Villanueva del Duque, España: Ayuntamiento de Villanueva del Duque. 
- MOLINERO, J.A. (2014). La Catedral de la Sierra: Iglesia parroquial de San Juan Bautista de Hinojosa del Duque. Hinojosa del Duque, España: Ayuntamiento de Hinojosa del Duque, D.L.

- MOlinero, J.A. (2014). Retablos históricos de Los Pedroches. Pozoblanco, España: Ayuntamiento de Pozoblanco.

- RANCHAL COBOS, Alfonso. (1968). Iglesia y torre de Pedroche. Revista Omeya. (nº 11). Córdoba.

- SANCHEZ PUIG, Daniel. (Mayo 1946). Dos iglesias de la Comarcal de Córdoba: Los Blázquez y Alcaracejos. Reconstrucción. (63), pp. 173- 184.

- SANTOS CABALLERO, Germán (1955). Historia de Alcaracejos y su escudo. Alcaracejos, España: Editado por Ayuntamiento de Alcaracejos.

- UNA HIJA DE MARÍA. (10 de diciembre de 1932) Alcaracejos. El defensor de Córdoba: diario católico, año 34 ( ${ }^{\circ}$ 11125). Córdoba. Pp. 2.

- VALVERDE FERNANDEZ, Fco. (2002). Actas del III congreso de historia de Andalucía. Córdoba, España: Publicaciones obra social y cultural CajaSur

- VECINO ANÓNIMO. (28 de octubre de 1931). Alcaracejos. El defensor de Córdoba: diario católico, año 33 ( $n^{\circ}$ 10788). Córdoba. Pp. 2.

Webgrafía

- ANONIMO. (2013). Alcaracejos. Andalucía rústica. Recuperado de http://andaluciarustica.com/ alcaracejos.htm. Consultado el 10 de abril de 2016.

- ANONIMO. (9 de abril de 2016). Historia de Alcaracejos. Wikipedia la enciclopedia libre. Recuperado de https://es.wikipedia.org/wiki/Alcaracejos. Consultado el 11 de abril de 2016.

- ARS NOVA, Restauración de bienes culturales, S.L. La crucifixión de Cristo y su significado iconológico. Ars Nova. Recuperado de http://arsnovarestauraciones.es/apuntes-de-iconograf\%$\mathrm{C} 3 \% \mathrm{ADa}$-en-el-cat $\% \mathrm{C} 3 \% \mathrm{~A} 1$ logo-de-ars-nova-restauraciones/la-crucifixi\%C3\%B3n-y-su-significado-iconol\%C3\%B3gico/. Consultado el 12 de mayo de 2016.

- CABAllero nAVAS, José. (20 de mayo de 2014). Virgen de Guía (Córdoba). Infovaticana. Recuperado de http://infovaticana.com/2014/05/20/virgen-de-guia-cordoba/. Consultado el 11 de mayo de 2016.

- CAMARASA, Vicente. (7 de noviembre 2014). La iconografía bizantina (II). La Virgen. Blogspot. Recuperado de http://seordelbiombo.blogspot.com.es/2014/11/la-iconografia-bizantina-ii-la-virgen.html. Consultado el 12 de mayo de 2016.

- CONSEJERIA DE CUlTURA, Junta de Andalucía. (-). Ruinas visigodas del Cerro del Germo. Patrimonio inmueble de Andalucía. Recuperado de http://www.iaph.es/patrimonio-inmueble-andalucia/resumen.do?id=i3715. Consultado el 15 de enero de 2016. 
- FERNANDEZ-BACA CASARES, Román. Retablo, terminología básica ilustrada. Iaph. Recuperado de http://www.iaph.es/sys/productos/retablos/index2.php?id=1. Consultado el 30 de mayo de 2016.

- GARCIA HIDALGO, Cipriano. (8 de enero de 2016). Breve historia del retablo en Madrid. Cipripedia. Recuperado de https://cipripedia.wordpress.com/2016/01/08/breve-historia-del-retablo-en-madrid/. Consultado el 20 de abril de 2016.

- GEAS ORTIGAS, Jaime. Nuestra Señora del Perpetuo Socorro. 7. Significado de la imagen. Devocionario Católico. Recuperado de http://www.devocionario.com/maria/socorro_7.html. Consultado el 12 de mayo de 2016.

- GUADALINFOALCARACEJOS. (13 de febrero 2009). Historia de Alcaracejos. Cordobapedia. Recuperado de http://cordobapedia.wikanda.es/wiki/Historia_de_Alcaracejos. Consultado el 11 de abril de 2016.

- LATORRE COVES, J.A. La imagen del Perpetuo Socorro. Blogspot. Recuperado de http://almoradi1829.blogspot.com.es/2013/06/la-imagen-del-perpetuo-socorro.html. Consultado el 12 de mayo de 2016.

- LOPEZ RIZQUEZ, Miguel. (16 de julio de 2010). ¿Dónde está San Nicolás? y ¿Quién es Nicolás de Tolentino? Blogspot. Recuperado de http://alcaracejosdigital.blogspot.com.es/2010/07/ quien-es-nicolas-de-tolentino.html. Consultado el 12 de febrero de 2016.

- MAIER, Jorge. (2000). Comisión de antigüedades de la Real Academia de la Historia. Andalucía, catalogo eindices. Madrid, España: Real Academia dela Historia.Pp.185-186. Recuperado de https:// books.google.es/books?id=_F3V_XNcXdAC\&pg=PA186\&lpg=PA186\&dq=pila + bautismal + alcaracejos\&source $=$ bl\&ots $=$ vMgMbDRKna\&sig $=$ E5rsPuUHYAayRdM1zGrjYmcRGro\&hl=es\&$\mathrm{sa}=$ X\&ved=0ahUKEwjUs_yU9dHKAhWFtBoKHR0hAPoQ6AEIJDAB\#v=onepage\&q\&f=false

- MARQUEZ, Domingo. (2013). Monumentos en Córdoba: Alcarcejos iglesia de San Andrés. Andalucía rustica. Recuperado de http://andaluciarustica.com/alcaracejos-iglesia-de-san-andres.htm. Consultado el 10 de abril de 2016.

- MÁRQUEZ, Rafael (27 de junio de 2015). Ntra. Sra. del Perpetuo Socorro. Rafaes. Recuperado de http://www.rafaes.com/html-2004/santoral-virgen-perpetuo-socorro.htm. Consultado el 07 de junio de 2016.

- MERINO MADRID, Antonio. (13 de diciembre de 2009). Patrimonio perdido de Los Pedroches/18. La iglesia de San Andrés de Alcaracejos. Solienses. Recuperado de http://solienses.blogspot.com. es/2009/12/patrimonio-perdido-de-los-pedroches18.html. Consultado el 15 de enero de 2016.

- MERINO MADRID, Antonio. (16 de abril de 2009). Antiguas imágenes religiosas perdidas. Solienses. Recuperado de http://solienses.blogspot.com.es/2009/04/antiguas-imagenes-religiosas-perdidas.html. Consultado el 11 de mayo de 2016. 
- MERINO MADRID, Antonio. (21 de noviembre de 2009). Patrimonio perdido de Los Pedroches/17. La ermita de Santa Ana de El Viso. Solienses. Recuperado de http://solienses.blogspot. com.es/2009/11/patrimonio-perdido-de-los-pedroches17.html. Consultado el 15 de Enero de 2016.

- MERINO MADRID, Antonio. (27 de diciembre 2012). Arte románico en Hinojosa del Duque. Solienses. Recuperado de http://solienses.blogspot.com.es/2012/12/arte-romanico-en-hinojosa-del-duque.html. Consultado el 11 de mayo de 2016.

- MERINO MADRID, Antonio. (9 de septiembre de 2009). Patrimonio perdido de Los Pedroches/7. El convento de San Alberto de El Viso. Solienses. Recuperado de http://solienses.blogspot.com. es/2009/09/patrimonio-perdido-de-los-pedroches7-el.html. Consultado el 15 de enero de 2016.

- REGIS, Defensor, (3 de diciembre de 2010). El mosaico y la pintura en Byzancio. Blogspot. Recuperado de http://toparcasaneugenio.blogspot.com.es/2010/12/el-mosaico-y-la-pintura-en-byzancio.html. Consultado el 12 de mayo de 2016.

- SBTN, Sbtn. (17 de diciembre de 2015). Calvario. Blogspot. Recuperado de http://alcaracejospuntocom.blogspot.com.es/2015/12/calvario.html. Consultado el 12 de febrero de 2016.

- SBTN, Sbtn. (24 de octubre 2015). La ermita de St ${ }^{a} \mathrm{M}^{\mathrm{a}}$ Magdalena. Blogspot. Recuperado de http://alcaracejospuntocom.blogspot.com.es/2015/10/difuntos-y-la-ermita-de-st-m-magdalena. html. Consultado el 11 de mayo de 2016.

- SBTN, Sbtn. (6 de agosto 2015). Alcaracejos, 1.840, Luis Ma Ramírez de las Casa-Deza. Blogspot. Recuperado de http://alcaracejospuntocom.blogspot.com.es/2015/08/alcaracejos-1840-luis-m-ramirez-de-las.html. Consultado el 12 de febrero de 2016

\section{- Normativa APA sexta edición -}

Webs consultadas:

- http://andaluciarustica.com/

- http://arsnovarestauraciones.es/

- http://censoarchivos.mcu.es/CensoGuia/archivodetail.htm?id=1627610

- http://cordobapedia.wikanda.es/

- http://dialnet.unirioja.es/

- http://prensahistorica.mcu.es

- http://www.alcaracejos.es/

- http://www.bibliotecavirtualdeandalucia.es/opencms

- http://www.buenastareas.com/

- http://www.cervantesvirtual.com/ 
- http://www.coam.org/

- http://www.iaph.es/web/

- http://www.pedrocheenlared.es/

- http://www.revistadepatrimonio.es/

- http://www.solienses.com/

- https://cipripedia.wordpress.com/

- https://es.wikipedia.org/

Lugares de consulta:

- Archivo diócesis de Córdoba.

- Archivo histórico de Córdoba.

- Archivo histórico provincial de Córdoba.

- Archivo municipal Alcaracejos.

- Archivo municipal de Pozoblanco.

- Biblioteca diocesana de Córdoba.

- Biblioteca municipal de Pozoblanco.

- Biblioteca provincial de Córdoba.

- Escuela de arquitectos de Córdoba. 


\section{Agradecimientos}

Asunción Jodar Miñarro, Teresa Puerto Fernández, José López Navarrete. 


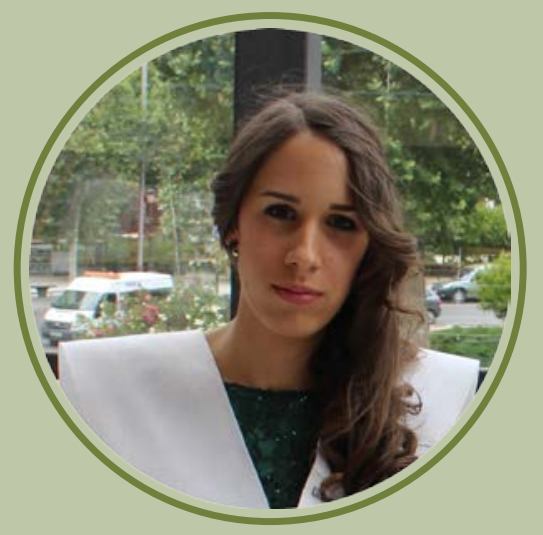

Educación Academica

- Graduada en Bellas Artes. Universidad de Granada, 2011- 2015.

- Situación actual. Estudiante de Máster oficial Dibujo: Creación, producción y difusión. Universidad de Granada.

- Curso de Inglés UIMP (Universidad Internacional Menéndez Pelayo), sede La Coruña. 40 horas lectivas.

- Curso Diseño y maquetación, dibujo vectorial. Universidad de Granada 75 horas lectivas.

- Curso online Marketing digital. Organizado por Google y Activate. 40 horas lectivas.

- Taller El empleo en Europa. Universidad de Granada. 4 horas lectivas.

- Taller Marca personal. Universidad de Granada. 4 horas lectivas.

- Taller Desarrollo de la carrera investigadora. Universidad de Granada. 1,5 horas lectivas.

- Curso Arte y creación digital 3D. Ayuntamiento de Granada. 16,5 horas lectivas.

- Taller Ikeando.Universidad de Granada. 2 horas lectivas.

- Taller Emprendimiento colectivo. Universidad de Granada. 1 horas lectivas.

\section{Idiomas}

- Español. Nativo.

- Inglés Nivel B1. Trinity College London.
Competencias

Capacidad de trabajo en equipo

Responsabilidad

Interés

Motivación 
Administración y venta en taquilla.

Ayuntamiento de Alcaracejos. Junio 2012.

- Clases de dibujo y pintura.

Programas informáticos

Taller de Grabado La Granja. Abril 2016.

\section{Curriculum Artístico}

Exposición colectiva I Concurso de escultura de la Fundación Sierra Elvira y departamento de escultura de Universidad de Granada. Atarfe, Noviembre 2015.

Finalista del I Concurso de escultura de la Fundación Sierra Elvira y departamento de escultura de la Universidad de Granada. Atarfe, Noviembre 2015.

Creación de la imagen corporativa para la empresa Asesoría Jurídica Soledad. Año 2015.

Participación en el XIII Festival de música española de Cádiz, Dibujando la música. Año 2015.

- Obra en los fondos del Museo de arte de Cádiz. Año 2015.

- Primer premio para el cartel de la representación teatral Coloquios de la infancia de Jesús, diseño de papelería y formato audiovisual para Canal Sur Televisión.

Alcaracejos, Córdoba. Año 2015.

Exposición colectiva Meetup para jóvenes creadores Art Boulevard, Fundación Antonio Gala. Enero 2015, centro cultural Caja Sur, Córdoba.

Exposición colectiva de escultura Hasta que la muerte nos separe. Noviembre 2014. Centro Cultural Medina Elvira de Atarfe, Granada.

Diseño Cartel Semana Santa Alcaracejos. Año 2014.

Exposición colectiva de fotografía. Año 2011 centro Guadalinfo, Alcaracejos, Córdoba.

Exposición Colectiva Arte Joven. Ayuntamiento de Hinojosa del Duque, Córdoba. Año 2011.

\section{Otros}

- Permiso de conducir B. 


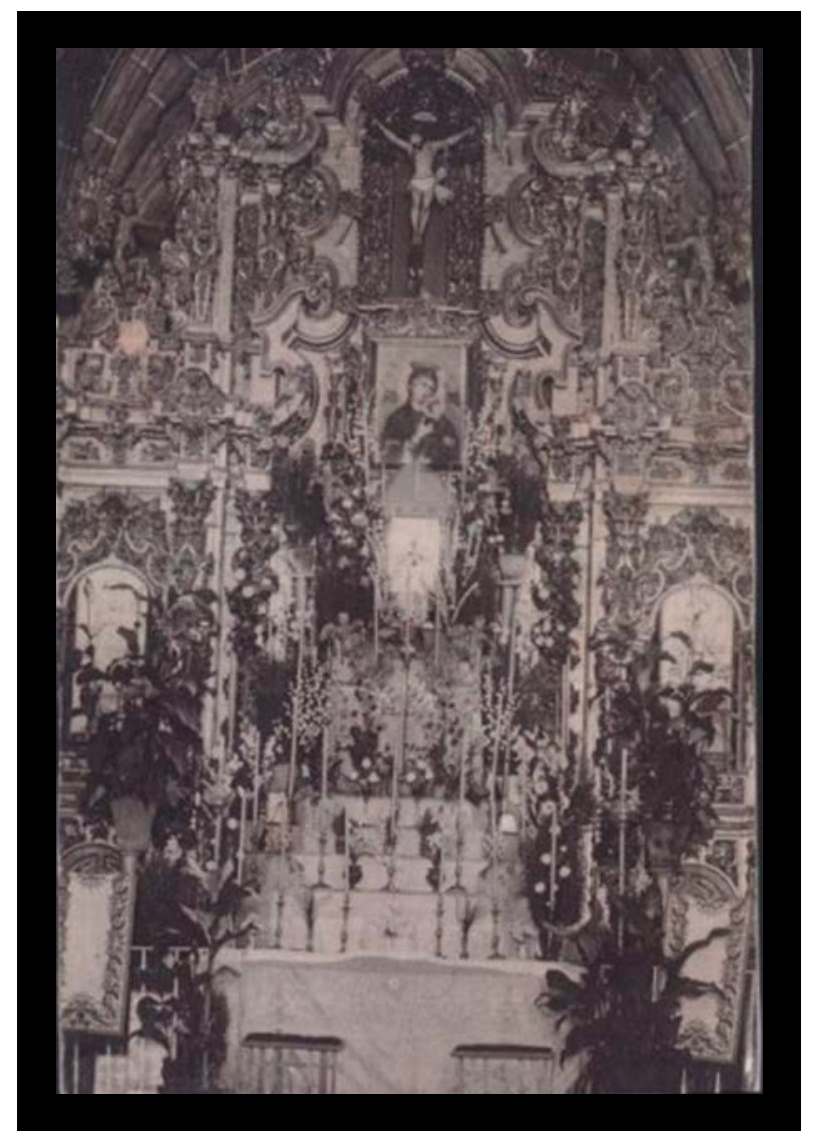



M.I.P.F. 